\title{
Modernising the Law: Breaches of the Peace \& Justices of the Peace
}

\author{
Graham McBain ${ }^{1,2}$ \\ ${ }^{1}$ Peterhouse, Cambridge, UK \\ ${ }^{2}$ Harvard Law School, USA \\ Correspondence: Graham McBain, 21 Millmead Terrace, Guildford, Surrey GU2 4AT, UK. E-mail: \\ gsmcbain@aol.com
}

Received: July 31, 2015 Accepted: August 15, 2015 Online Published: August 24, 2015

doi:10.5539/jpl.v8n3p158 URL: http://dx.doi.org/10.5539/jpl.v8n3p158

\section{Introduction}

Justices of the Peace ('JP's) - also called magistrates - are the 'work-horses' of the criminal law. They handle the lesser criminal offences. The office of JP derives - at least - from the early $14^{\text {th }}$ century (and, possibly, considerably earlier). From an early time, JP's were encumbered with a heterogeneous collection of duties, such that they were sometimes performing criminal - and sometimes civil - tasks. Presently, there are some 26,000 JP's serving throughout England and Wales. It is an unsalaried post, although expenses are paid. Over the course of the centuries, many legal texts have been written on JP's (see Appendix A). However, they are now dated. Today, the principal practitioner texts comprise:

\section{- Stone, Justices Manual; ${ }^{1}$ \\ - Archbold, Magistrates' Courts Criminal Practice. ${ }^{2}$}

The purpose of this article is to consider how the law relating to JP's may be consolidated and improved in order to modernise it - as well as made it more accessible to JP's, lawyers and laymen. In particular, the following is asserted:

- Concepts. The Germanic (and Anglo-Saxon) concepts of the 'peace' and 'breach of the peace' are no longer applicable (or intelligible) since, today, breach of the peace ('BOTP') means (if anything), breach of the criminal law. Further, reference to a magistrate (or judge) is more appropriate and intelligible than to a 'justice of the peace' which title should now be dispensed with in legislation;

- Criminal Offence. BOTP was never - even from Anglo-Saxon times - a criminal offence in itself. ${ }^{3}$ Instead, it referred to any offence which - if not punished - would provoke a blood feud (faida);

- Frankpledge \& Hue \& Cry. These common law obligations - long obsolete - should be abolished;

- Justices of the Peace Act 1361. This Act is spent - including the right of JP's to bind over for good behaviour. It should be repealed since the Magistrates' Courts Act 1980 now covers all (non-obsolete) matters referred in the former;

- Justice of the Peace Act 1968, s 1(7). This section should be amended to exclude reference to binding over for 'BOTP' and for 'good behaviour'. Instead, to make it more intelligible in modern times, it should refer to the power to bind over where a person: (a) has committed a crime; or (b) threatened to commit a crime; or (c) incited another to commit a crime;

- BOTP- Duty of Constable. The common law duty of a constable to prevent 'breaches of the peace' should be replaced by a statutory duty, requiring a constable to 'do his best to prevent the commission of crime' (following Watkins LJ in Howell);

- Citizen - Arrest without Warrant. This common law power should be abolished since the Police and Criminal Evidence Act 1984 ('PACE 1984'), s 24A now adequately covers matters;

\footnotetext{
${ }^{1}$ The first edition of this work was S Stone, The Justices' Pocket Manual ( $1^{\text {st }}$ ed, 1842).

${ }^{2}$ The first edition of this work was in 2004.

${ }^{3}$ Under Anglo-Saxon law, acts that would otherwise lead to a blood feud (i.e. acts which 'breached the peace') were punished. Because Anglo-Saxon law did not separate civil, from criminal, law, there was no direct reference to 'breaches of the criminal law', as such.
} 
- Constable - Arrest without Warrant. This common law power should be abolished since the PACE 1984, s 24 now adequately covers matters (or should be slightly amended to do so). Further, this section should be amended to also cover where a constable does not arrest as such but 'restrains' or 'detains' or 'removes' a person, since these acts are often part of arrest or closely connected to it;

- Constable - Entering Private Premises. This common law power should be abolished since the PACE 1984, s 17 adequately covers matters (or should be slightly amended to do so);

- Criminal Legislation. All criminal legislation should be consolidated into 4-5 Acts - in order to help JP's with their work and to make the law more accessible and efficient;

- Courts Legislation. Legislation relating to magistrates' courts should be consolidated - along with that relating to the other courts - into one Act (with obsolete courts being abolished and others merged). This, in order to made the court system more efficient and intelligible;

- More Stipendiaries. JP's should now be professional lawyers - given the increasing complexity of the criminal law and the need to ensure the greatest prospect of justice being secured.

These issues are now considered, regard, first, being had to the concepts of 'peace' and BOTP.

\section{Meaning of 'Peace'- Germanic Law ${ }^{4}$}

When lawyers refer to 'justices of the peace' - and their duty to keep the 'peace' - they do not, often, readily appreciate that these concepts are old, pre-dating Anglo-Saxon law. And, that they derive - not from Roman law but from early Germanic law. Reference is made to Germanic law in this article, since Anglo-Saxon law derives from the same and - for both - the legal concepts of 'peace' and BOTP were important components, vis-a-vis their criminal aspects.

\section{(a) Germanic Law - History}

In the $3^{\text {rd }}$ century $\mathrm{AD}$, the Roman empire started to decline as it was encroached on, on all sides. ${ }^{5}$

- In the case of encroachment by German tribes, this was a process of constant osmosis, not least, since as a result of the decline in the Roman population caused by various catastrophes in the $3^{\text {rd }}$ century large numbers of Germans were drafted to serve in the Roman army; ${ }^{6}$

- $\quad$ By the $4^{\text {th }}$ century, the fall of the Roman empire exacerbated and it was unable to sustain, militarily, its borders.

As a result, a large number of Germanic tribes moved into the Roman empire, across Gaul and Italy, establishing kingdoms. The tribes most commonly referred to comprised:

- Visigoths; ${ }^{7}$

- Ostrogoths; ${ }^{8}$

- $\quad$ Lombards $^{9}$

\footnotetext{
${ }^{4}$ Useful texts on these laws comprise: (a) KF Drew, The Laws of the Salian Franks (University of Pennsylvania Press, 1991); (b) KF Drew, The Lombard Laws (University of Pennsylvania Press, 1973); (c) KF Drew, The Burgundian Code (University of Pennsylvania Press, 1972); (d) SP Scott, The Visigothic Code (Boston Book Co, 1910); (e) TJR Rivers, Laws of the Salian and Ripuarian Franks (AMS Press, 1987). These texts cite further bibliography.

${ }^{5}$ For the Roman empire, the $3^{\text {rd }}$ century was one of almost continual civil war, barbarian invasions, plague and economic collapse. Barbarian invasions into the Roman empire resulted (in part) from a push westward by the Huns from Asia.

${ }^{6}$ Drew, 4 (Lombard Laws), p 4.

${ }^{7}$ The Visigoths crossed the Danube frontier in the last part of the 4th century. After much friction with Rome, they were allowed to settle in southwest Gaul as federate allies. Later, they settled in Spain, their kingdom being destroyed by the Arabs in AD 711-9.

${ }^{8}$ The Ostrogoths crossed the Danube and were encouraged to settle in Italy in the late $5^{\text {th }}$ century. Their king, Odoacer, established a kingdom there, in the north, in AD 476. It was destroyed by Theodric (another Ostrogoth) who governed the Roman population of Italy from AD 491, dying in $\mathrm{AD} 526$. The Ostrogoths were then defeated by armies of the emperor Justinian (who ruled the Eastern Roman empire from the city of Constantinople), which armies first invaded Italy in AD 534. Justinian formally announced the restoration of Roman imperial rule in Italy on 13 August 554. However, Roman rule only lasted until AD 568, before being challenged by the Lombards. The law books of the Ostrogoths have not survived, see Drew, n 4 (Laws of the Salian Franks), p 25.

${ }^{9}$ The Lombards (who may have originally come from Scandinavia) entered Italy in AD 568 (Justinian died in AD 565). By AD 571, they had established themselves in the north of the peninsula and in two areas - Spoleto and Benevento (to the east, and south, of Rome). This left the Romans controlling the northeast, the duchy of Rome and the far south of Italy. Later, the Franks challenged the Lombards and the latter kingdom fell by AD 774. Drew, n 4 (Lombard Laws), p xi 'The successful expeditions of Pepin [king of the Franks, AD 751-68] and Charlemagne precipitated the fall of the Lombard kingdom in 774 and the transformation of the imperial enclave that was papal Rome into the kernel of the later papal state. Lombard law survived in the Frankish north of Italy, however, and after the decline of Carolingian imperial
} 


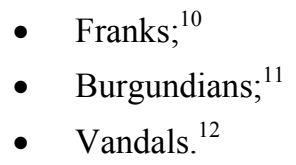

These tribes established kingdoms which were (eventually) superceded by (or merged into) the empire of Charlemagne (king of the Franks, AD 768-814) ${ }^{13}$ who was crowned Roman emperor, at Rome, in AD $800 .^{14}$

\section{(b) Germanic Codes}

Originally, the laws of the Germanic tribes were customary - being kept in the memories of elders of the community who, when needed, were called together to 'speak the law'. ${ }^{15}$ However - beginning in the early sixth century - the rulers of Germanic kingdoms inside the Roman Empire turned to compiling codes of law for their Roman and German subjects. Although these codes were Germanic, they often borrowed elements of Roman law. ${ }^{16}$ The more important of these codes comprise the following: ${ }^{17}$

- Visigoths. Modern scholarship asserts that c.AD 458, king Theodoric II issued his Edictum Theodorici an abbreviated code of law for his Roman and Gothic subjects (although, previously, it was thought that this was issued later, c. AD 508). ${ }^{18}$ A further Visigothic code was compiled under the authority of king Alaric II (AD 485-507) c. AD 506. It is known as the Breviary of Alaric (also called the Lex Romana Visigothorum or Breviarium Alaricianum). This code, which took much from Roman law, ${ }^{19}$ was

power in the ninth century, Lombard principalities in the south of Italy remained, face to face with their old enemies, the Byzantine forces. Not until the eleventh-century Norman conquest of southern Italy and Sicily did these last Lombard territories fall.'

${ }^{10}$ The Franks, an agglomerate of Germanic peoples under war leaders (dukes or kings) who had been living to the east of the lower Rhine river, had made incursions into the Roman empire since the $3^{\text {rd }}$ century and settled in north eastern Gaul. They were scattered at first and then formed into two major groupings: Salian Franks (the more westerly) and Ripurian Franks (to the east and up the Rhine). The first Merovingian king (from the name of its semi-mythical founder, Merovech) was the Salian ruler, Childeric. He died in AD 481 and was succeeded by his son Clovis. The last western Roman emperor (Romulus Augustulus) was deposed in AD 476 and the Franks (Ripuarian and Salian) were united by Clovis in AD 509. By AD 534, most of Roman Gaul was under Frankish rule. In Italy, the Franks destroyed the Lombard kingdom by 774 (see n 9).

${ }^{11}$ The Burgundians settled in the southeastern part of Gaul and established a kingdom, AD 413-534. They fell under the control of the Franks when the latter, in the $5^{\text {th }}$ century, bought all Gaul under Frankish control.

${ }^{12}$ These Germanic tribes settled in north Africa, establishing a kingdom there in AD 429. Their kingdom was destroyed by the forces of Justinian (see n 8) in AD 534. The law books of the Vandals have not survived, see Drew, n 4 (Laws of the Salian Franks), p 25.

${ }^{13}$ Drew, $\mathrm{n} 4$ (Laws of the Salian Franks), p 11 notes that Charlemagne united the 'Franks in a series of military campaigns that extended Frankish rule down into the northeastern part of Spain (a campaign that can be regarded as the beginning of the Christian re-conquest of Spain from the muslim Moors who had over thrown the Visigothic kingdom in 711); into Italy (overthrowing the Lombard kingdom in 774); and deep into Germany by conquest of the Saxons, Thuringians, and Frisians, and establishing protectorates over some of the Germanic and Slavic peoples living further even to the east.'

${ }^{14}$ The unitary nature of the kingdom was not to last, ending in division again in AD 834.

${ }^{15}$ Drew, $\mathrm{n} 4$ (Laws of the Salian Franks), p 20.

${ }^{16}$ As for the Code of Justinian, Drew, 4 (Lombard Laws), p xi 'The dismal condition of Italy between 534 and 568, however, did not provide fertile ground for the legal genius of Justinian's composition, and the Corpus Juris Civilis had to wait until the revival of Roman legal studies in the eleventh century before its full force and majesty began to influence western European law in any substantial way. Italy, like the other Western provinces, preserved its own, pre-Justinian Roman law, and it is this vulgar law that plays a role in the history of the relations between the Roman provincials and their barbarian masters between the fifth and eighth centuries. Roman vulgar law in the various forms in which it existed during this period is an important chapter in the history of the shaping of early Italian law.' Drew, n 4 (Laws of the Salian Franks), pp 12, 33-4 contains a useful analysis (ch 2) as to the development of Roman law.

${ }^{17}$ There were other codes - such as the Ripruarian, Alamannian, Bavarian, Saxon, Thuringian and Frisian codes (see also n 23).

${ }^{18}$ Drew, 4 (Laws of the Salian Franks), p 22.

${ }^{19}$ Ibid, p 23 'The Breviary was compiled by a commission of jurists working under instructions from the king...the Roman jurists who accomplished this task used many sections of the Theodosian Code [a compilation of Roman law issued by the Roman emperor Theodosius in 438]...plus material from the sentences of Paul and from a vulgar compendium of the Institutes of Gaius [a legal text on Roman law written c. 161], as well as from some less important Roman law sources. The Breviary was thus a very respectable statement of vulgar Roman law.' Drew, n 4 (Lombard Laws), p xiii-iv 'In [this Visigothic Code] an abridged version of Pauli Sententiae appeared [composed in the $3^{\text {rd }}$ century, it contained extracts from earlier Roman jurists], along with other materials from late Roman law, and the influence of [it] in southern France and upon the law codes designed for the Roman subjects of barbarian kings in other provinces carried the influence of this single work, although in a much transformed condition, down to the eleventh century. Thus, the law shaped by barbarian rulers for their Roman subjects, as well as individual Germanic law codes that were designed for Romans and barbarians alike, took their 'Roman' materials from the legal literature of the fourth and fifth centuries.' 
revised in the mid- $7^{\text {th }}$ century and is known as the Leges Visigothorum (or Forum Iudicium). ${ }^{20}$ It remained in use in Spain during the Moorish domination of Spain; ${ }^{21}$

- $\quad$ Burgundians. In the $5^{\text {th }}$ century, king Gundobad (AD 474-516) and, later, his son and successor, king Sigismund (516-23) - issued codes. The Germanic code was issued in seven parts between AD 483-532. It is known as the Liber Constitutionum (Lex Gundobada). The code for the Roman population was issued c 517. It is known as the Lex Romana Burgundionum; 22

- $\quad$ Franks. Between AD 507-11, the first Salic code was issued under king Clovis (Pactus Legis Salicae). It followed Visigothic and Burgundian precedents (see above). In turn, Salic law influenced later codes. $^{23}$ Charlemagne (king of the Franks, AD 768-814) carried out a final revision of the Salic code. $\mathrm{He}$, then, effectively superceded, its original Germanic nature, by issuing a new kind of legislation; ${ }^{24}$

- Lombards. The Lombard codes of law were issued between AD 643-755. ${ }^{25}$ The Edict of Rothair (Edictum) was the first to be issued, in AD 643.

Although there is a considerable difference in these codes in respect of the Roman law content - the Visigothic being the most Romanised and the Anglo-Saxon (see 3) the most Germanic ${ }^{26}$ - in the criminal field much is similar. Further, as to Germanic law in general, Drew noted: ${ }^{27}$

- Personal. Germanic law was personal and not territorial. It belonged to each member of a people wherever they went. Thus, prior to the law being enforced by tribal leaders (called, dukes or kings), it was enforced by the family and kindred (maegth); ${ }^{28}$

- $\quad$ Limited Range. Germanic law tended to limit itself to a narrow range of social relations - principally those which would be called torts (injuries);

- $\quad$ Custom. Originally, Germanic law was customary and oral. ${ }^{29}$ And, when codes were issued, they did not (openly) purport to change the prior oral law; ${ }^{30}$

\footnotetext{
${ }^{20}$ Drew, n 4 (Laws of the Salian Franks), p 23 'The Visigothic Code is the most Romanized of the early Germanic codes - it lacks such typically Germanic legal concepts as collective family responsibility symbolized by the threat of the blood feud and popular participation in the judicial or legislative process. In addition most of the judicial procedure is basically Roman, depending on a strong state where the king is the source of law; and the judicial system, backed by strong state control and operated by state magistrates, has superceded private or family justice.'

${ }^{21}$ It was incorporated into a Castilian code - the Seven Part Code (Siete Partidas) published in 1348 by Alfonso the Wise of Castille. See also Scott, n 4, pp xxiv-v. For an English translation of the Seven Part Code ,see SP Scott (trans), Las Siete Partidas (University of Pennsylvania Press, 2001, ed RI Burns).

${ }^{22}$ Drew, n 4 (Laws of the Salian Franks), p 24 'The Lex Romana Burgundionum was set aside and replaced by the more comprehensive Visigothic Breviary, which would have been the chief source of Roman law in the Frankish empire.' See also Drew, $\mathrm{n}$ (Burgundian Code), pp 5-6.

${ }^{23}$ Ibid, p 9 'written codes were provided under the stimulus first of Merovingian and later of Carolingian Frankish leadership. Thus the laws of the Ripuarian Franks were codified in the early seventh century along with those of the Alamanni, and the earliest version of the Bavarain laws may go back to this period also. These laws were revised and laws issued for the Saxons, Thuringians, and Frisians in the late eighth and ninth centuries by Charlemagne [AD 768-814]. These later 'codes' (Ripuarian, Alamannian, Bavarian, Saxon, Thuringian, and Frisian) are alike, however, in that they were prepared under Frankish leadership and reflect significant Salic influence.'

${ }^{24}$ Ibid, p 11 'Charlemagne began what is usually thought to be an essentially new kind of legislation: he issued numerous instructions or memoranda (usually called capitularies from the custom of dividing them into 'chapters') that dealt with many aspects of law and thus created a layer of what might be called imperial law over the Salic, Visigothic, Burgundian, and east German underneath.'

${ }^{25}$ Ibid, $\mathrm{n} 4$ (Lombard Laws), p xix. See also, pp 21-4.

${ }^{26}$ Drew, $\mathrm{n} 4$ (Laws of the Salian Franks), p 27. However, Drew noted the following similar characteristics of these Codes (regardless of the degree of Roman content): 'All reflected the fact that much of the responsibility for maintaining peace and order in the community had passed from the family to the state. All envisaged a judicial system staffed by royal appointees who either conducted the proceedings alone or who presided over a court that contained representatives of the community. All handled criminal offences as injuries against an individual or his family, and the judicial action to resolve the issue was essentially a suit for civil damages. All (except possibly the Visigothic) relied on the co-operation of the family in order to obtain justice, for the State as such merely provided a court for arbitration; it was up to the injured party (backed by his kin) to get the accused before the court. Once an issue had been settled in court, however, the injured family was liable to judicial interference if it attempted to resort to the blood feud.'

${ }^{27}$ Drew, $\mathrm{n} 4$ (Lombard Laws), p xiv.

${ }^{28}$ Ibid, (Laws of the Salian Franks), p 21.

${ }^{29}$ Ibid, pp 32-3 'Little is known about the Germanic court system before the Germans established contact with Rome. Before the invasions, the Germanic state was weak, if nonexistent, and whatever judicial system there was depended heavily on the cooperation of the kin groups and the threat of blood feud to maintain some semblance of peace. Once the Germans settled within the Empire, their judicial systems were immediately influenced by the Roman model; but the resulting product was different for each Germanic people.'
} 
- Borrowed. The entry of the German peoples into the Roman empire meant that their law borrowed, to a degree, aspects of Roman law - transforming both. ${ }^{31}$

\section{(c) Germanic Criminal Law}

Germanic law did not distinguish between criminal, and civil, law. It treated all suits as private ones - where criminal suits tended to be civil suits for damages, rather than the trial of public crimes. ${ }^{32}$

- $\quad$ Tariff System. At the heart of German criminal law was a tariff system of fines payable in punishment for the battery of another person - whether this battery was by way of killing, rape, wounding or other means. ${ }^{33}$ The 'tariff' system was designed to suppress the former system of blood feud (faida) in which the family of a wronged person was obliged to take revenge against the perpetrator of a crime; ${ }^{34}$

- King acts as Arbiter. As the Germanic kings became more powerful, a 'community' system of justice - with the community ordering the payment of compensation (bot) to avert a blood feud - was replaced by one in which the king exercised justice and in which part of the compensation payable ${ }^{35}$ was paid to him by way of a fine (wite) for acting as a judge;

- Wergeld (Blood Money). For the purposes of assessing compensation, the basic unit was the 'wergeld' - the sum payable for a man's life. ${ }^{36}$ Given that Germanic society was hierarchical, the level of wergeld depended on the status of the person killed or injured (e.g. noble, freeman, slave etc). Also, on the location where this occurred. The wergeld was high, in order to dis-incentivise violence. ${ }^{37}$ At an early stage, a victim could refuse compensation and demand the application of the lex talionis (an eye for an eye etc). ${ }^{38}$

\section{(d) Peace \& BOTP}

To avoid the blood feud, it was necessary to return to the status quo ante - the state of peace. Drew stated:

$\mathrm{Th}[\mathrm{e}]$ Germanic method of judicial redress of grievances was a method to maintain the peace worked out in the dim past. Behind it lay the threat of the blood feud: if an injured party or his family were unrecompensed, he or they would wreck vengeance on the offender or his family...

Under Germanic (but not Roman) law, 'peace' (grio, grith) connoted not just the absence of war - and, in a lesser context, the absence of a public disturbance. ${ }^{39}$ It reflected what the Germans perceived to be a person's own

\footnotetext{
${ }^{30}$ Drew, $\mathrm{n} 4$ (Lombard Laws), $\mathrm{p}$ xiv 'The prologues to most codes of barbarian law insist upon the point that the lawgiver, the king, is simply collecting the laws of the people, not making new laws.'

${ }^{31}$ Ibid, 'the novel experience of the Germanic peoples once they had entered and settled inside the Empire called for a certain amount of borrowing from existing Roman law...'

${ }^{32}$ Drew, $\mathrm{n} 4$ (Laws of the Salian Franks), pp 12, 33-4.

${ }^{33}$ All the laws (including those of the Anglo-Saxons, see 3) contained detailed tariffs which were similar in nature as to the listing of injuries to the human body.

${ }^{34}$ Drew, n 4 (Laws of the Salian Franks), p 35 'The penalty in all but the most serious offences...consisted in the assessment of a monetary payment, a payment called composition [bot] in the case of injuries less than death and wergild in the event of homicide. Composition was an amount fixed by the laws, which were very detailed in this regard.' See also p 8. See also Tacitus, On Britain and Germany (written AD 97-8, Penguin, 1954), p 118 'A man is bound to take up the feuds as well as the friendships of father or kinsman. But feuds do not continue unreconciled. Even homicide can be atoned for by a fixed number of cattle or sheep, and the satisfaction is received by the whole family. This is much to the advantage of the community, for private feuds are peculiarly dangerous side by side with liberty.'

${ }^{35}$ Drew, $\mathrm{n} 4$ (Lombard Laws), pp 7-8, considered that 'By the fifth century...the family group had already lost its role as the sole guarantor of peace and security for its individual members. The State instead had assumed this function... The blood feud as a means of securing justice was now formally prohibited by the State (not always successfully of course), and the State assumed the role of an umpire in disputes between individuals or families.' See also W Holdsworth, A History of English Law (2009 rep), vol 2, p 43.

${ }^{36}$ Drew, $\mathrm{n} 4$ (Laws of the Salian Franks), p 35 'Wergeld [there are variant spellings] was an amount that varied with the individual; it was a man's (or woman's) value. These payments were made to the injured party (or to his family in the case of homicide); with the acceptance of payment, the injured party had to be content.' As to wergild differing with status, see pp 45-9. Also, pp 8-9.

${ }^{37}$ Ibid, p 36 'The compositions and wergelds were very high, in the case of serious offences, and most families must have preferred to receive money (or some other form of wealth) in compensation rather than resort to a costly feud. The state was likewise recompensed for its efforts to maintain the peace. The man who had been 'proved' guilty of a particular offence not only paid composition to the injured party, he also paid a fine to the court.'

${ }^{38}$ For example, in the Visigothic Code, see Scott, n 4, p 211. See also, J Goebel, Felony and Misdemeanor. A Study in the History of Criminal Law (1976), ch 1 re the development of compensation, to buy-off the blood feud.

${ }^{39}$ In various translations of the texts referred to in $\mathrm{n} 4$, the word 'disturbance' is employed to translate 'scandalum'. Further, these Codes were not concerned with private quarrels (such as intra-family disputes); they were concerned with acts of violence which affected other members of the community. See also Holdsworth, n 35, vol 2, p 47.
} 


\section{'space' or area of legal protection (mund). Thus:}

- Inflicting injury on a person's body was to invade their 'peace'; 40

- By extension, a person's home - and courtyard ${ }^{41}$ - was also within their 'peace'. To invade it, therefore, was to commit the crime of hamsocn (house breaking, the precursor to burglary); ${ }^{42}$

- To challenge the king - including his sovereignty and protection ('mund') in respect of criminal matters, as reflected in his role as an arbiter or judge - was to challenge the 'king's peace' (to commit 'mundbryce', breach of royal protection). ${ }^{43}$ Further, hamsocn in the case of the king (such as fighting in his palace or courts) was even more severely punished, as appropriate to his superior status; ${ }^{44}$

- Since the Catholic church was influential in drawing up the codes, ${ }^{45}$ the idea of 'church peace' (Christ's admonition, 'blessed are the peacemakers') ${ }^{46}$ also developed. This was, in part, to protect clerics from violence. Also, to extend the church's influence - including in the legal sphere.

In short, in Germanic law, there developed a legal concept of 'peace' - not only to signify the absence (or return to the absence) of a blood feud - but also to signify a 'sphere of legal protection', whether personal, kingly or divine. In those Codes which were usually in latin, 'peace' was 'pax' and the word for disturbing it, 'scandulum' - later termed 'breach of the peace' in English. Drew states:

The theoretical justification for royal control of the judicial system may well have developed from the combination of two concepts: the idea that every man's person and property constituted a special domain protected by a peace which it was an offence to violate, and the attitude that the kingdom was in effect the personal domain of the king and as such it was protected by a peace the violation of which was an offense against the royal power. To breach this royal peace was to commit an offence that the Lombards termed scandalum. ${ }^{47}$ A number of the laws specifically state that a particular fine is to be imposed in order to avert the faida (the blood feud) ${ }^{48}$ and hence prevent a [BOTP] or scandalum.

\footnotetext{
${ }^{40}$ A person's body included their hair and clothing. Hair reflected the social, and legal, status of a German person. Thus, it was a great affront for a freeborn German to have his (or her) head shaved. Boys and girls under the age of 12 (in some cases, the age limit was older for boys) had long hair. After 12, boys had their hair cut and girls had their hair tied up. The codes contain a number of offences relating to hair. See also GS McBain, Modernising the Common Law Offences of Assault and Battery (2015) International Law Research, vol 4, no 1, pp 39-155.

${ }^{41}$ This extension to cover a person's home may have come from an analogy to the palace and courtyard of a king. Goebel, n 38, p 13 'The Germanic house is palisaded, a fact which at once suggests an analogy to the enclosure of the court-place.' Goebel also suggested that a person's house (being enclosed) might have been treated as having a sacral character, like a church. Drew, n 4 (Lombard Laws), p 241 'A man's peace, which entitled him to certain protective rights so far as his person was concerned, was also extended to include his house and courtyard. A man enjoyed, in a sense, certain sovereign rights so far as his house was concerned and hence any violation of his 'boundaries' was a very serious offence.'

${ }^{42}$ Hamsocn was to enter a person's house or courtyard, in order to do (or threaten) violence to them (or their family). In England, this offence continued into Norman times, e.g. H Bracton (trans Thorne), On the Law and Customs of England c.1240 (Cambridge UP, 1968-76). Bracton is now online, see bracton.law.harvard.edu. See vol 2, p 408 (hamsocn) 'where one defends himself against hamsocn, which [the English call] the entering of a house in breach of the peace, and the intruder is slain, he will be free of liability if he who killed could defend himself in no other way.' See also LJ Downer, Leges Henrici Primi (Oxford, 1972), p 253.

${ }^{43}$ This was also reflected in the protection sovereigns' accorded to foreign ambassadors and, later, to foreign merchants.

${ }^{44}$ English retains a common law offence to this day. See McBain, $\mathrm{n} 40$.

${ }^{45}$ The German kings often used jurists skilled in Roman law. Further, they were likely connected to the church, since many of the statements in the codes reflect a Christian content. BR O'Brien, God's Peace and King's Peace. The Laws of Edward the Confessor (Univ. of Pennsylvania Press, 1999), p 23 notes that 'The Forum Iudicium of the Visigoths was composed by bishops at the request of kings...'. Anglo-Saxon law was similar. Ibid, pp 23-4.

${ }^{46}$ Matthew, ch 5, v 9 'Blessed are the peacemakers, for they will be called the sons of God' (The Compact NIV Study Bible, New International Version, 1985). See also Goebel, n 38, pp 12-3. O'Brien, n 45, p 14, the answer of clerics to stop military violence was the "peace of God, a sworn agreement by nobles and the clergy not to harm noncombatants, and the 'truce of God', a similarly sworn agreement not to fight at particular times (for example, during a holy season'. Also, p 16 'Blessed are the peacemakers', said Christ, and so eleventh-century Christians issued in written edicts their responses to what they perceived to be a rising tide of violence, using methods developed by the Frankish bishops and English kings to preserve their peace that were detailed in their council canons and royal laws.' See also p 63 et seq. Also, Goebel, n 38, p 297 et seq.

${ }^{47}$ Drew, $\mathrm{n} 4$ (Lombard Laws), p 239 'Scandalum seems to have been the offense of disturbing the public peace, depending in seriousness on the nature of this 'peace breaking'. If the peace were broken in a non physical manner, the offense was much less serious than if physical violence were involved. Similarly, the place where the public peace was broken also affected the seriousness of the offense, for scandalum in the presence of the king or even in the district (civitas) where the king was present was much more serious than scandalum in that district where the king was not present.' Also, p 250 'a [BOTP] implied violence (although it did not necessarily bring violence)...'.

${ }^{48}$ As for matters for which a blood feud could be waged, Goebel, n 38, p 19, noted that they included 'homicide, wounds and bodily injury, imprisonments, injuries to honor, false accusations, violations of mundium (king's personal protection), abduction, seduction, rape, robbery, theft, malicious destruction of property, arson, breaking into a home (in the sense of the ags [Anglo-Saxon]. hamsocn), sorcery and perjury.'
} 
The penalty for breaking the peace increased the closer the violence came to the person of the king: hence the commission of scandalum in the city where one of the royal officials was present was definitely breach of the royal peace but it was a less serious [BOTP] than the commission of scandalum in the city where the king himself was present. Nonetheless, any violent act was a form of scandalum and was thus an offence against the public peace as well as an offence against the injured individual or family. The royal courts therefore considered two offences when they judged any violent act or any act that might lead to violence in retaliation, and accordingly the penalty, the compensation, was divided between the two offended parties; the royal court (the fisc) and the private party. ${ }^{49}$ (wording divided for ease of reference)

Thus, the Crown became - to an increasing extent - the guarantor of 'peace' (and the one punishing infractions of it). In short, justice became a fiscal tool - with the incentive on the Crown to monopolize it.

\section{(e) References to 'Peace' in the Germanic Codes}

Below, are examples of how 'peace' was used in Germanic codes.

- In the Salic law, Christ's 'peace' is referred to, as well as the distinction between 'peace' and 'criminal acts' (BOTP);

- The Lombard laws reflect the status element which pre-dominated in Germanic law. A BOTP was punished more severely it came closer to the king. Further, since allegiance to the king (and to a lord) was a central feature of Germanic law, so too it became possible to equate a BOTP (what we would call a breach of the criminal law) with an act of disloyalty to the king. This culminated in the supreme act of disloyalty - treason. ${ }^{50}$

As to these (italics are supplied):

- Salic Law. The Salic law of Clovis states:

- In its preamble: 'The whole Frankish people, established by the power of God...firm in the compact of peace...Let him who esteems the Franks live by the present decree...May Jesus Christ... bestow with his gracious love the joys of peace';

- [Also] 'It was pleasing and agreed to between the Franks and their notables that to preserve peace among themselves they should with care prevent all growth of quarrels. And just as their nation was pre-eminent among other peoples located next to it on account of the strength of its arms, so also it should undertake to make an end to criminal acts with its legal authority. ${ }^{51}$

- Lombard Laws. Rothair's Edict states:

- Art 8: 'He who creates a disturbance (scandalum) in the council or other assembly shall pay 900 solidi as composition to the king., ', ${ }^{52}$

- Art 35: 'He who creates a disturbance (scandalum) in a church shall pay forty solidi to that venerable place in addition to [the composition paid to] him who suffered the wounds or injuries. ' ${ }^{53}$

- Art 36: 'He who dares to create a disturbance (scandalum) within the king's palace when the king is present shall lose his life unless he can redeem his life from the king. $; ;^{54}$

- Art 37: 'The freeman who creates a disturbance in that district (civitas) where the king is present, although he does not strike a blow shall pay twelve solidi to the king's palace [i.e. to the royal fisc]. But he who raises a disturbance and also strikes a blow, shall pay twenty-four solidi to the fisc... ${ }^{55}$

\footnotetext{
${ }^{49}$ Ibid, p 25.

${ }^{50}$ Although the English law of treason contains some elements of Roman law the pre-dominant feature is that it can only be committed by a subject, one who owes allegiance to the king. See generally, GS McBain, Abolishing the Crime of Treason (2007) 81 ALJ 94-134.

${ }^{51}$ Drew, $\mathrm{n} 4$ (Laws of the Salian Franks), p 171.

${ }^{52}$ Ibid, (Lombard Laws), p 54.

${ }^{53}$ Ibid, p 59 ((on him who breaks the peace (commits scandalum) in a church).

${ }^{54} \mathrm{Ibid}, \mathrm{p} 59$ (on him who breaks the peace (commits scandalum) in the palace where the king is present).

${ }^{55}$ Ibid, p 59 (concerning the freeman who breaks the peace (commits scandalum) in a district (civitas) where the king is present). See art 38 re a slave breaking the peace. Also, arts $39 \& 40$ (freeman or slave breaking the peace in another district). Also, art 378 (free women involved in a brawl).
} 


\section{(f) Germanic Law: Peace \& BOTP - Conclusion}

The following may be noted:

- Germanic laws posited the need for an absence of 'war' - being 'peace' (pax). This - at a lesser level included the absence of public disturbance. It also connoted legal protection, itself, an emanation of sovereignty;

- 'Peace' also fitted in well with the clerical idea of it being the duty of every Christian to uphold Christ's peace. Indeed, it is likely it was the Catholic church and clerics who promoted this legal concept in the Germanic codes, as well as a threefold peace. That is: God's peace, the king's peace and the individual's peace, ${ }^{56}$

- Under Germanic law, breach of its criminal law ('breach of peace' or 'breach of the peace') ${ }^{57}$ was punished with the payment of a (large) fine - with the State assuming an ever greater portion of this as it, increasingly, dispensed justice - taking it out of the hands of laymen and the kin (or communal) units.

In conclusion, to the modern lawyer (and one suspects to a Germanic jurist, if there had been a separation between civil, and criminal, law in his time):

- if the Germanic legal concept of 'peace' was, alternatively, re-worded as a reference to the 'criminal law'; and

- 'breach of the peace' was re-worded as a reference to 'breach of the criminal law',

this would not be inaccurate. ${ }^{58}$ These Germanic concepts of peace, and BOTP, were also reflected in Anglo-Saxon law, which is now considered.

\section{Anglo-Saxon Law - Breach of the Peace ${ }^{59}$}

\section{(a) Anglo-Saxon Britain ${ }^{60}$}

Anglo-Saxon law (AD 597-1066) should be considered in the context of British society at that time. With the decline of the Roman empire in the $3 \mathrm{rd}-5^{\text {th }}$ centuries, the Romans left Britain to fend for itself as from c. 410 . Thereafter, Germanic tribes from Saxony (Anglo-Saxons, also called Saxons or Angles) migrated - in increasingly large numbers - to Britain and they had subdued it, 'probably during the very years of Justinian's re-conquest of Italy.' (i.e. AD 534-54). ${ }^{61}$ Drew noted:

various Germanic peoples known as the Anglo-Saxons settled in Britain between the middle of the fifth and the middle of the sixth centuries. ${ }^{62}$

Since - unlike in Continental Europe - the Roman authorities did not continue to maintain a physical presence in Britain, the implementation of Germanic law in Britain was virtually entire. This was likely helped by a:

\footnotetext{
${ }^{56}$ As dukes and other magnates received the franchise of kingly prerogatives (including the right to hold a court and punish crimes) so did the duke's peace (or lord's peace) develop.

57 'Breach of the peace', even in Anglo-Saxon times, would have been better termed 'Breach of public peace'. Further, 'the' suggests a degree of specificity which was not there - given that the expression referred to any criminal act creating a disturbance, whether murder, rape, riots etc.

${ }^{58}$ It must be remembered that both Germanic, and Anglo-Saxon law, were rudimentary in nature without all the legal sophisticism of modern day law. Therefore, 'war' and 'peace' - both civil war and in the context of lesser communal strife - would have been (and needed to be) readily understandable to illiterate peasants (and kings). When a man was fined therefore (or in the cases of non-emendable offences, executed), he would have been told that this was because he broke the king's law (peace, protection) or that of his lord or that of his neighbour. Doubtless, a priest may also have been on hand to remind him that he had also broken God's law (of obedience to the civil power and that of failing to 'love' his neighbour, by keeping Christ's peace). The church also developed the idea of 'sin' being a spiritual breach of God's law - one in which 'peace' could only be returned to, via 'penance - the latter often involving the payment of a fine to the church. Hence, criminal and ecclesiastical tariffs prevailed.

${ }^{59}$ FL Attenborough, The Laws of the Earliest English Kings (NY, 1963) and AJ Robertson, The Laws of the Kings of England from Edmund to Henry I (Cambridge UP, 1925)(the latter covers legislation from AD 942 up to the reign of Henry I (1100-35)). See also B Thorpe (ed), Ancient Laws and Institutes of England (1840). For the asserted laws of Edward the Confessor (1042-66) see O'Brien, $\mathrm{n} 45$. For a useful analysis see also F Pollock \& FW Maitland, The History of English Law (Cambridge UP, 1968) ('P \& M'), vol 1, ch 2. See also G Crabb, A History of English Law (London, 1829), chs 2-4, Goebel, n 38, ch 6 and JH Baker, An Introduction to English Legal History (4 ${ }^{\text {th }}$ ed, 2002), ch 1 .

${ }^{60}$ See generally, FM Stenton, Anglo-Saxon England ( $\left.{ }^{\text {rd }} \mathrm{ed}, 1971\right)$ and F Palgrave, History of the Anglo-Saxons (1876). See also J Hudson, The Oxford History of the Laws of England (OUP, 2012).

${ }^{61}$ Drew, n 4 (Lombard Laws), p vi. Also, p viii 'It took a century for the Anglo-Saxons to subdue the resistance in Roman Britain, but subdue it they did.' The first landing of the Jutes appears to have been in AD 449.

${ }^{62}$ Ibid, (Laws of the Salian Franks), p 25.
} 
- decline in Britain's (and Europe's) population ${ }^{63}$ as a result of war and plague;

- movement of many Britains to Gaul and Brittany, possibly, impelled (in part) by climate change;

- breakdown of central government in Britain into more isolated units, with small kingdoms. ${ }^{64}$

\section{(b) Anglo-Saxon Legal System}

Few Anglo-Saxon laws have come down to us ${ }^{65}$ and - as Pollock and Maitland pointed out - those which have, are likely to be mere 'superstructures on a much larger base of custom. ${ }^{66}$ That said, the following may be noted:

- The earliest extant Anglo-Saxon code appears to be that of Aethelbert, king of Kent (AD 558-616) ${ }^{67}$ (there are variants to the spelling of his name). When it was issued is unclear. However, it seems likely this was between AD 597-616;

- Athelbert's code ${ }^{68}$ comprises some 90 provisions. The majority of the crimes reflected in them comprise battery in some form - whether it be murder, rape or wounding - without any categorisation (or specific legal distinction) being made between them. ${ }^{69}$

This 'tariff' system - one which, like its Continental counterpart, was designed to suppress blood feuds continued from the laws of Aethelbert until the Norman Conquest of 1066. Indeed, it continued until, at least, the Laws of Henry I (c. 1113) - if not until c. 1189 (see 5). ${ }^{70}$ Implicit within this criminal law system were the concepts of 'peace' and the 'king's peace.'

\section{(c) Anglo-Saxon Criminal Law}

As with Germanic law, Anglo-Saxon law made no distinction between criminal, and civil, law. In the criminal field - as might be expected in a society which was very rudimentary (and rural) and with a very low degree of literacy - the number of crimes was few. Not least, since they would have had to have been known by heart by a 'law speaker' (asega), one who assisted the judge by providing information on the law and legal procedure. As to the content of Anglo-Saxon law, Pollock \& Maitland noted:

In so far as we can trust the written laws, the only topics of general importance were manslaying, wounding, and cattle stealing. ${ }^{71}$

To this might be added sexual offences such as adultery and fornication.

\footnotetext{
${ }^{63}$ This could have been by, as much as, $50 \%$.

${ }^{64}$ As from AD 866, Danish armies (Vikings) began to winter in England - as opposed to just raiding periodically. They brought with them their Danelaw. Eventually, the Danes put an end to all English kingdoms, save for that of Wessex.

${ }^{65}$ Attenborough, n 59, cited: (a) the Kentish laws of Aethelberht (AD 558-616), Hlothhere and Eadric (AD 673-685/6), Eadric (AD 685-6) and Wihtred (690/1-725); (b) laws of Ine (AD 688-725) and of Alfred (AD 871-99); (c) a treaty of Alfred and the danish king Guthrum (AD c 878-90) and the laws of Edward (the Elder, 899-924) and Guthrum (asserted, more recently, to have been written, c AD 1000, by Wulfstan II, Archbishop of York (AD 1002-23); (d) the laws of Edward the Elder (AD 899-924) and of Aethelstan (AD 924-39). Robertson, n 59, cited: (a) laws of Edmund (AD 939-46) and Edgar (AD 943-75); (b) Promissio Regis (a coronation oath composed for Edward the Martyr (AD 975-8) or Aethelred II (AD 978-1016)); (c) the laws of Aethelred (AD 865-71); (d) the laws of Canute (1016-35). Robertson also cited the 'laws' of William I (AD 1066-87)(viz. a charter to the City of London, Regulations concerning exculpation, Epispocal laws, Ten Articles and Articuli Retractati) as well as various laws of Henry I (1100-35) viz. a Coronation charter, a Decree concerning Coinage, a Decree concerning the county and hundred courts, and a charter to the City of London.

${ }^{66} \mathrm{P} \& \mathrm{M}, \mathrm{n}$ 59, vol 1, p 27

${ }^{67}$ Ibid, 'We have in the first place the considerable series of laws and ordinances of Saxon and English princes, beginning with those of Aethelbert of Kent, well known to general history as [saint] Augustine's convert, which are of about the end of the sixth century.'

${ }^{68}$ FW Maitland, The Collected Papers of Frederick William Maitland (Cambridge UP, 1911), vol 2, p 420 'To call this brief tariff a code may seem strange, but there are not wanting signs that the wise men of Kent are committing to writing as much of their traditional law as they can remember in the form of abstract propositions.'

${ }^{69}$ See Attenborough, n 59, pp 5-17 and Thorpe, n 59, pp 1-10 (for the laws). See also P Wormald, The First Code of English Law (Canterbury Commemoration Society, 2005), p 61. The other provisions of Aethelbert's code mainly covered theft, robbery and trespass.

${ }^{70}$ Downer, $\mathrm{n} 42$.

${ }^{71} \mathrm{P} \& \mathrm{M}, \mathrm{n} 59$, vol 1, p 38. Ibid, $\mathrm{p} 43$ 'The only substantive rules that are at all fully set forth have to do with offences and wrongs, mostly those which are of a violent kind, and with theft, mostly cattle lifting.' See also JF Stephen, A History of the Criminal Law of England (Macmillan \& Co, 1883), vol 1, ch 3. As to the codes promulgated by the Anglo-Saxon kings, O'Brien, $\mathrm{n} 45$, pp 21-2: 'the cumulative effect of the issuing of such codes was the creation of a visible tradition of royal legislation. The topics of the legislation remained relatively consistent over time: kings protected the Church, maintained the peace, stipulated tariffs for personal injury, fought theft, and organized policing of some sort. The detail of the codes reveal the concern of English kings with the prevention of crime, particularly theft, and the prosecution of criminals through regulation of the smallest 'institutional' units of their society, the tithings and borh [i.e. pledge] groups.'
} 
- In all these cases, the tariff was followed, ${ }^{72}$ with a categorisation of the crime and the financial penalty in the form of payment of ' $b o t$ ' (compensation) to the victim or his family and the payment of 'wite' (a fine) to the king. ${ }^{73}$ By the $10^{\text {th }}$ century, it is likely that ' $b o t$ ' was merged into ' wite'. And, that the latter was solely paid to the king (or the church) $;^{74}$

- As with the Germanic systems of law, the quantum of tariff payable reflected the status of the victim and the location where the criminal act occurred. ${ }^{75}$

\section{(d) Breach of the Peace}

Anglo-Saxon law - like Germanic law- contained similar legal concepts of 'peace' and 'breach of the peace. ${ }^{.76}$ Pollock \& Maitland state:

Preservation of the peace and punishment of offences were dealt with, in England as elsewhere, partly under the customary jurisdiction of the local courts, partly by the special authority of the king. In England that authority gradually superceded all others.

All criminal offences have long been said to be committed against the king's peace; and this phrase, along with the 'king's highway', has passed into common use as a kind of ornament of speech, without any clear sense of its historical meaning. The two phrases are, indeed, intimately connected; they come from the time when the king's protection was not universal but particular, when the king's peace was not for all men or all places, and the king's highway was in a special manner protected by it.

Breach of the king's peace was an act of personal disobedience, and a much graver matter than an ordinary breach of public order; it made the wrong-doer the king's enemy. The notion of the king's peace appears to have had two distinct origins. These were, first, the special sanctity of the king's house, which may have been regarded as differing only in degree from that which Germanic usage attached everywhere to the homestead of a free man; and, secondly, the special protection of the king's attendants and servants, and other persons whom he thought fit to place on the same footing. In the later Anglo-Saxon period the king's particular protection is called grio as distinct from the more general word frio. ${ }^{77}$ The rapid extension of the king's peace till it becomes, after the Norman Conquest, the normal and general safeguard of public order, seems peculiarly English. ${ }^{78}$

The statement of Pollock \& Maitland is useful, especially that 'All criminal offences have long been said to be committed against the king's peace'. This would seem accurate since the king was assuming, to an increasing extent, the role of the upholder of 'public peace' (i.e. criminal law). Further, his criminal jurisdiction was extending in Anglo-Saxon times from his palace and court to:

- $\quad$ public highways and waterways;

\footnotetext{
${ }^{72}$ Ibid, vol 2, p 47. 'A freeman's life has a regular value set upon it, called wergild, literally man's price or man-payment, [also called blood money] or oftener in English documents wer simply; moreover, for injuries to the person short of death there is an elaborate tariff.' Maitland, $\mathrm{n}$ 68, p 427 'We have called the written laws 'tariffs'. They prescribe in great detail the various sums of money which must be paid by wrong-doers. There are payments to be made to the injured person or the kinsfolk of the slain man; there are also payments to be made to the king, or some other representative of the tribe or nation.' JRC Hall, Concise Anglo-Saxon Dictionary (4 ${ }^{\text {th }}$ ed, 1975 rep) defined 'bot' as compensation for an injury or wrong by way of a 'peace offering.'

${ }^{73}$ A Harding, The Law Courts of Medieval England (1973), p 15 'Here is the fine payable for 'crime', the penalty due to the 'public' authority, alongside the 'civil' damages payable to the private plaintiff: the difference from modern law is that both were payable for the same wrongs.'

${ }^{74}$ Wormald, $\mathrm{n} 69$, pp 14-5 'By the tenth century, royal action is the norm, and bot is payable not to victims, and/or their families but to the king, or God (i.e. the church). We may by that stage, if not under Aethelberht, think in terms of 'crime' and 'punishment." For commentary on the feud, the tariff and wer see P \& M, n 59, vol 1, pp 46-8.

${ }^{75} \mathrm{P} \& \mathrm{M}, \mathrm{n} 59$, vol 1, p 32. Crabb, n 59, p 38 'To prevent the causes and beginnings of quarrels, laws were made against every breach of the peace, but particularly in certain places, or before certain persons, whose presence the Saxons were taught in a particular manner to respect.' As to status, in Anglo-Saxon England, there was the king, eaols (earls), thegns (thanes), ceorls (ordinary freeman), serfs (villeins) and various categories of slaves.

${ }^{76}$ Ibid, p 44 'in its general features, Anglo-Saxon law is not only archaic, but offers an especially pure type of Germanic archaism.'

${ }^{77}$ Ibid, p 45 'Although the proper name [grio] is of comparatively recent introduction and of Scandinavian extraction, the thing seems to answer to the Frankish sermo or verbum regis, which is as old as the Salic law.' Goebel, n 38, p 423 'In Anglo-Saxon dooms the word peace (frith) is used generally in an unartful sense of public order or general security...'

${ }^{78} \mathrm{Ibid}$, 'On the continent the king appears at an early time to have been recognized as protector of the general peace, besides having power to grant special protection or peace of the higher order. It is not clear whether there was any fixed name for the general peace which was protected only by the hundred court and the ealdorman. Very possibly the medieval usage by which an inferior court was said to be in the peace of the lord who held the court may go back in some form to the earliest time when there were any set forms of justice...' See also F Pollock, Oxford Lectures and Other Discourses (1890), ch 3 (the king's peace).
} 
- the protection of foreign ambassadors and merchants; ${ }^{79}$

- those to whom he gave his personal protection (handgrio, handgrith).

\section{(e) References to 'Peace' in Anglo-Saxon Law}

Anglo-Saxon law, like Germanic law, made reference to different types of peace:

- 'Church peace' (pax ecclesiae, ciricgrio), deriving from Christ's 'peace' and 'protection'; 80

- 'King's peace'. There may have been a distinction between 'frio' (frith) and 'grio' (grith) with the latter being more localised and the king's protection being restricted to particular places or persons. ${ }^{81}$ However, by the $11^{\text {th }}$ century, such an etymological distinction likely dis-appeared. ${ }^{82}$ Handgrio was the peace given by the hand of the king - as opposed to that conveyed by writ or that which was associated with particular days or events; ${ }^{83}$

- Individual's 'peace.' Each man had his own peace, which included his house and courtyard; ${ }^{84}$

In the case of references to 'peace' and BOTP, the following are examples (italics supplied):

- $\quad$ Laws of Edmund (king, AD 939-46). The first of these laws (which emphasised the need to suppress the blood feud $)^{85}$ commenced:

- Now, it has seemed to us first of all especially needful that we all steadfastly maintain peace and concord among ourselves throughout all my dominion. I myself and all of us are greatly distressed by the manifold illegal [criminal] deeds of violence which are in our midst... ${ }^{86}$

- Also,'These are the provisions for the preservation of public peace (de pace) and the swearing of allegiance which have been instituted at Colyton by king Edmund and his bishops, together with his councillors ${ }^{87}$

- $\quad$ Laws of Edgar (king, AD 943-75). His laws state, inter alia:

○ 'I am very well pleased with you all, because you are so zealous for the preservation of the public peace (frio); 88

\footnotetext{
${ }^{79}$ O'Brien, n 45, p 14, noted that the Anglo-Saxon kings 'had extended special security or peace (Old English mund, frio or grio) to those they had brought into the kingdom - mercenaries, merchants and monks - in order to protect them from bodily harm and murder...The extension of royal mund or grio to protect newcomers and the recognition of a people's customs as the law of their land had ensured, with a few striking exceptions, the peaceful accommodation of the English with the Danes and Norwegians settled in northern and eastern England, and therefore had encouraged the formation of an Anglo-Scandinavian society united by political allegiance to one king and exhibiting a blending of culture at the local level.'

${ }^{80}$ Thus, the opening words of the first law (or doom) of Aethelbert (see n 67) states: '[Theft of] God's property and the Church's shall be compensated twelve fold; a bishop's property eleven fold; a priest's property nine fold; a deacon's property six fold; a clerk's property three fold. Breach of the peace shall be compensated doubly when it affects a church or a meeting place.' (italics supplied). See also O'Brien, $\mathrm{n} 45$, p 24 citing a treatise of Archbishop Wulfstan (see n 65), which contains a sermon on the sins of injuring the clergy 'because every church peace is Christ's own peace.' See also Goebel, n 38, p 298 et seq, Attenborough, n 59, p 5 and O’Brien, n 45, pp 63-4.

${ }^{81}$ See also Baker, $\mathrm{n} 59, \mathrm{p} 8$ 'what is protected is not the safety of the community but the peace (grith) of particular persons. In this concept of peace, what we regard as public and private rights are indistinguishable; the peace of the churl was simply his right to compensation for wrongs done to him and his family, but the peace of a lord included the protection of his vassals and was a right more akin to jurisdiction than a cause of action.'

${ }^{82}$ Robertson, n 59, p 297 'Grio is a Scandinavian loan word. It denotes 'peace' in a limited or localized sense, ie. the sanctuary afforded by special places or the protection granted by a particular person, cf. its compounds ciricgrio and handgrio.' Also, p 335 'The verb grioian, derived from the Scandinavian loan word grio, begins to appear in the eleventh century...It is found often along with the rhyming frioian. Lieberman [a German academic] regards the two terms grio and frio as practically synonymous by the time of Aethelred [AD 865-71, see $\mathrm{n}$ 65]...but suggests that if there is any underlying difference between them, frio has the special sense of security against assailants, while grio implies the privilege of assuring safety to others.' See also Hudson, $\mathrm{n} 60$, pp 162-3.

${ }^{83}$ See O'Brien, n 45, p 216.

${ }^{84}$ Harding, n 73, p 14 'Every ceorl or yeoman had his peace...within his family and in the area around his house...' Pollock, n 78, pp 73-4 'every man has his own peace, of which the breach is a special offence. But the great man's peace is of more importance than the common man's, and the king's peace is above all, and is broken at the hazard of the offender's life and goods.'

${ }^{85}$ Robertson, n 59, pp 8-11.

${ }^{86}$ Ibid, p 9. Robertson notes that 'Pax is the latin word regularly employed to translate the AS [Anglo-Saxon] frio.' Ibid, p 298.

${ }^{87}$ Ibid, p 13. These laws (designated by Robertson as 'Edmund III') are of uncertain date. However, they were, probably, promulgated at Culinton (probably Colyton, in Devonshire). Ibid, p 3.

${ }^{88}$ Ibid, p 39. These laws (designated by Robertson as 'Edgar $I V$ ') were probably issued c. AD 962-3.
} 
- The coronation promise of (likely) Edgar (in AD 973) states: 'In the name of the Holy Trinity I promise three things to the Christian people who are under my authority. Firstly, the true peace shall be assured to the church of God and to all Christian people in my dominions.' 89

- $\quad$ Laws of Aethelred (king, AD 978-1016). His laws state:

○ 'This is an ordinance which king Aethelred and his councillors have enacted, at Woodstock in Mercia, for the promotion of public security (frioes), wherever English law prevails;' 90

- A truce reached, probably in AD 991, between king Aethelred and a Danish (Viking) fleet led by Olaf Tyggvason and Justin and Guomund, the son of Stegita, states: 'A general truce (woroldfrio) shall be established between king Aethelred and all his subjects and the whole (Viking) fleet to which the king has paid tribute, in accordance with the terms which Archbishop Sigeric and ealdorman Aethelweard and ealdorman Aelfric made, when they obtained the king's permission to purchase peace (frio) for the districts which, subject to him, they ruled over... 91

○ 'These are the constitutions which king Aethelred and his councillors have enacted at Wantage for the promotion of public security (frioes bote). 1. Namely, that the king's peace (grio) shall continue to be maintained in accordance with the highest standards observed in the days of his ancestors, so that breach of the peace which he establishes in person ${ }^{92}$ shall not be atoned for by any payment of compensation. But for breach of the peace (grio) which the ealdorman or the king's reeve establishes in the Court of the Five Boroughs, ${ }^{93} 1200$ of silver shall be paid as compensation. And for breach of the peace (grio) established in the court of one borough 600 [of silver] shall be paid as compensation, and 100 for that established in a wapentake. In the case of breach of the peace in an ale house, 6 half marks shall be paid as compensation if a man is slain, and 12 ores if no-one is slain. ${ }^{94}$

- 'we have decreed that a man who, within the town, makes forcible entry into another man's house without permission and commits a breach of the peace of the worst kind (summam infracturam aget de placito ungebendeo)...shall lie in an unhonoured grave." 95 Also, 'the promotion of public security (frioes)...shall be diligently attended to..." ${ }^{96}$ Also, 'Public security (frioes) shall be promoted in such a way as shall be best for the householder and worst for the thief." 97

- Laws of Canute (king, 1016-35). His laws state, inter alia: 'in the Danelaw he [the king] has the receipt of fines for fighting, neglect of military service, breach of the peace (griobryce)... ${ }^{98}$ Also, 'Breach of the peace (griobryce). If anyone is guilty of a capital deed of violence while serving in the army, he shall lose his life or his wergeld. If he is guilty of a minor deed of violence, he shall make amends according to the nature of the deed. 99 Also, 'it is my will that every man shall be entitled to protection (grioes) going to and from assemblies, unless he be a notorious thief. 100

Laws of Edward the Confessor (1042-66). O'Brien, in this work on this asserted collection of laws of Edward the Confessor ('asserted' because it is not proved that Edward the

\footnotetext{
${ }^{89}$ Ibid, p 43. For the reasoning as to why this oath was likely that of Edgar, see pp 40-1. The reference to 'peace' in the text likely included both church peace and the king's peace (with the latter's variants). See also Hudson, n 60, p 19.

${ }^{90}$ Ibid, p 53. These laws (designated by Robertson as 'Edmund III') were, probably, issued pre-1013.

91 Ibid, p 57.

92 That is Handgrio, see n 83. Not 'atoned' meant that it was not emendable, see ns 104. See also, Hudson, n 60, p 20.

${ }^{93}$ Ibid, p 74 These laws (designated by Robertson as 'Aethelred $I V$ ') were probably issued AD 991-1002. The Court of the Five Boroughs (Derby, Leicester, Lincoln, Nottingham, Stamford) was thought by Robertson to have been a kind of confederacy. Ibid, p 318. See also O'Brien, n 45, pp 53-4.

94 Ibid, p 65. These laws (designated by Robertson as 'Edmund III') were, probably, issued pre-1013. A wapentake was the same as a hundred (a division of a county).

${ }^{95}$ Ibid, p 75. Robertson considered that '[BOTP] of the worst kind' probably referred to homicide.

${ }^{96}$ Ibid, p 87. These laws (designated by Robertson as 'Aethelred $V$ ') were probably issued c. 1008.

${ }^{97}$ Ibid, p 101. These laws (designated by Robertson as 'Aethelred $V I$ ') were probably issued c. 1008.

98 Ibid, p 181.

99 Ibid, p 205. These laws (designated by Robertson as 'Canute II') were probably issued c. 1020.

${ }^{100}$ Ibid, p 217. These laws (designated by Robertson as 'Canute II') were probably issued c.1020.
} 
Confessor actually issued them) described it as 'a commentary on legal categories of peace'. Thus, it considered 'God's peace' 101 and the 'king's peace', which had an internal symmetry. ${ }^{102}$ The king's peace could be general or personal - the latter granted by his hand (handgrio) or by writ and seal (breve or sigullum) ${ }^{103}$ Breaches of the peace could be emendable or not (the latter being treated as a contempt (overseunessa) of the king. ${ }^{104}$ The former were usually called by the common expression 'grithbryce' [breach of protection] and could be franchised out. The latter were usually not franchised out, but reserved to the king alone. ${ }^{105}$ Thus, for example, breaches of the peace arising from assault or fighting were emendable and they were often franchised out. ${ }^{106}$ As to these asserted laws of Edward the Confessor:

Art 1: 'And so, beginning with the Holy Church, by which king and kingdom are firmly supported, they declared its peace $[\mathrm{pacem}]$ and liberty before the assembly, saying: All the clergy and scholars and all their possessions, wherever they are, shall have the peace of God and of the Holy Church'; ${ }^{107}$

Art 12: 'There are many types of the king's peace: one is given by his hand, which the English call kings hand salde grid [i.e. handgrio]; another [is given] on the day on which he is first crowned - this one lasts for eight days; at Christmas eight days and eight days at Easter and eight at Pentecost; another is given by his writ; another which the four roads have, that is Watling Street, Fosse Way, Iknield Way, and Ermine Street... another held by the bodies of water on which victuals are brought by ship to cities and boroughs from various places'; ${ }^{108}$

Art 18: 'Nevertheless, if any offender asks for his [the king's] mercy from fear of death or loss of limbs because of his offence, he can pardon him, if it pleases [him] by the law of his dignity. And he who receives mercy shall do right to the person he wronged before, in so far as he is able to fulfil [the terms of compensation], and he shall find sureties for maintaining the peace [de pace] and [his] law-worthiness'; ${ }^{\prime 19}$

Art 20: 'There is another important peace by which all shall be maintained in a more lasting state, namely under the stability of a suretyship, which the English call friborgs, except for the people of Yorkshire, who call it tenmannetale, which is a count of ten men. And this means that all [the people] in all the vills of the entire kingdom had to be under the surety-ship of the tithing, so that if one of the ten should commit an offence, the nine would produce him for trial'; 110

Art 26: 'Concerning those who have the king's peace [pacem regis] either by hand [i.e

${ }^{101}$ See O'Brien, n 45, pp 36-7.

${ }^{102}$ O'Brien, n 45, p 37 'For example, as those travelling to churches for prayer are protected by the peace of God and the Church, so those journeying on the king's roads and waterways are under his peace. Noticeably absent...is any discussion of the abstract legal meaning of grio peace or any mention of its double, or cousin, mund 'protection, peace'. The author did not state principles; he did not imagine that the applications he described would have had greater clarity had he done so...Instead of principles, the author described some of the circumstances in which the peace of the king can be broken. He provided only a selection from the many possibilities - for instance, breach of a peace received from the king's hand (the kings hand salde grid) is mentioned, but not the king's peace given by an earl or sheriff.'

${ }^{103}$ Ibid, p 74. See also CK Allen, The Queen's Peace (Hamlyn Lecture, 1953), p 11.

${ }^{104} \mathrm{P} \& \mathrm{M}, \mathrm{n}$ 59, vol 1, p 48 'Some of the gravest offences, especially against the king and his peace, are said to be botleas, 'bootless'; that is, the offender is not entitled to redeem himself at all, and is at the king's mercy.' See also Holdsworth, $n$ 35, vol 2, p 48. Examples of the latter are: harbouring outlaws, housebreaking (hamsocn) and evading military service, see Allen, n 103, p 13. O'Brien, n 45, p 76 'hand- or-writ-given peace was unamendable, and breach of it placed a man at the king's mercy. This did not mean automatic execution; rather, the emendation for such a breach did not follow a predictable tariff. The king decided if a person could be spared execution and make amends and the amount of that compensation and fine. Other breaches of the peace were generally emendable for 100 shillings.' See also Stephen, n 71, vol 1, p 58.

${ }^{105}$ O'Brien, n 45, p 74. See also Goebel, n 38, p 401. See also Harding, n 73, p 15 and HM Cam, Law Finders and Law Makers in Medieval England (1962), chapter on The Evolution of the medieval English Franchise.

${ }^{106}$ As to how Anglo-Saxon and Norman kings enforced the 'peace' there was, from early times, a system of frankpledge (friborg) in operation which boys above the age of 12 were liable to perform. See GS McBain, False Imprisonment and refusing to assist a Police Officer-the Need for Statutory Offences [ ]. See also O'Brien, n 45, p 85, Holdsworth, n 35, vol 1, pp 13-5 \& 78 (frankpledge obsolete at the close of the fifteenth century) and Allen, $\mathrm{n} 103$, ch 4 (who asserts that frankpledge had fallen into disuse by the $14^{\text {th }}$ century, in part due to the rise of JP's).

${ }^{107}$ O’Brien, $\mathrm{n} 45, \mathrm{p} 159$. Church peace dealt with criminal seeking sanctuary, tithes, ordeals etc.

${ }^{108}$ Ibid, p 171. See also Allen, n 103, pp 13-4. Also, Hudson, n 60, p 387.

${ }^{109}$ O’Brien, n 45, p 177.

${ }^{110}$ Ibid, p 179. 
handgrio] or royal writ, let it be done (as it is of the greatest necessity to them) that they keep it against all law worthy men; ${ }^{111}$

Art 27: 'The peace given by the king's hand [pax data manu regis], and during the eight days in which he is crowned, and the peace of the feast days mentioned earlier, and the peace by the king's writ have one amount of compensation, and that by the judgment that is greater in the shire where the peace was broken. ${ }^{112}$

In conclusion, like Germanic law, Anglo-Saxon law made reference to 'peace' and BOTP. In both, 'peace' connoted legal 'protection'.

\section{Summary: Germanic \& Anglo-Saxon Law}

Anglo-Saxon law is usually perceived as the purest form of written Germanic law to have survived (see 2(b)) and the two share almost identical characteristics in respect of 'peace' and BOTP. Thus:

- 'Peace' (pax) was not just an expression as to the absence of war. In the legal context it was treated as: (a) a state where acts were not committed that might lead to a blood feud; and (b) a state to return to, via the payment of compensation, where such acts were committed - to avert a blood feud;

- BOTP, therefore, was a generic reference to crimes which might lead to a blood feud. It did not comprise, in itself, a criminal offence. This may be seen in the fact no Germanic or Anglo-Saxon tariffs recorded a BOTP as an offence requiring compensation, in itself;

- The 'king's peace' referred to the king's jurisdiction over criminal offences. One which, over time, would come to cover the geographical area which he controlled as king, as well as all offences which might lead to a BOTP; ${ }^{113}$

- By the time of the Conquest in 1066, it would not have been inapposite for 'breach of the king's peace' to be (alternatively) termed a 'breach of Crown law.' That is, breach of what, today, we would call the criminal law.

In conclusion, the basic components of 'peace'- and BOTP - were established in Anglo-Saxon times.

\section{Breach of the Peace Until 1189}

\section{(a) Norman Conquest \& William I (1066-87)}

When William I became king he encountered English law in three parts - Mercian law, West Saxon law and Danelaw (law of the Vikings). ${ }^{114}$ However, all three reflected the Anglo-Saxon concepts previously discussed. The extent to which William I (1066-87) maintained Anglo-Saxon law or imposed the ducal law of Normandy (which was scant) ${ }^{115}$ on his new subjects is uncertain. Modern analysis would suggest that much of the criminal law continued - not least since the Laws of Henry I clearly reflect a continuance of the Anglo-Saxon tariff system (see (c)). As to the position, post 1066, Stephen noted:

In nearly all the [Anglo-Saxon] laws provision is made for the breach of the king's, the lord's or the church's peace or protection (frith-bryce, mund-bryce) in such a way as to show that peace was an

\footnotetext{
111 Ibid, p 185.

112 Ibid, p 187.

${ }^{113}$ O'Brien, n 45, p 73 'By that time, the establishment of a peace in this way by the king was a traditional act in England. Anglo-Saxon kings had promoted a general peace as part of their attack on violent crime, as when Aethelred [see $\mathrm{n}$ 65] promulgated laws at Wantage 'to frioes bote' ('for the re-establishment of the peace')(see 2(e), for the relevant law). This linking of a general notion of royal responsibility to ensure the peace with attempts to eliminate violent crime and punish malefactors meant that as royal jurisdiction over crime grew, so too did the boundaries of this royal peace. From a vague statement of the inviolability of the king or his palace under the earliest English kings, this peace had grown considerably by the reigns of Aethelred and Cnut [AD 1016-35] and could be extended to individuals or single institutions (e.g. legates or churches), generally to those travelling to courts or assemblies, over the assemblies themselves, and over particular times and places. Perhaps any crime committed against those individuals, or in those places, or at those times constituted grithbryce 'breach of peace' alongside the crime itself, and made the offender liable for a fine to the king and sometimes for corporal punishment as well. In some cases breach of the king's peace was emendable, in others, not.' See also Baker, n 59, p 9 (who noted that, by the time of king Cnut, 'the concept of the king's peace provided the basis for a parallel jurisdiction over crime.' Pollock, n 78, p 75 'the king's peace was extended in respect of persons, occasions, and places.'

${ }^{114}$ The population of England at the time of the Conquest was small and widely scattered. Allen, n 103, p 4 'In 1086 the population of England, on the evidence of Domesday, is estimated to have been about a million and a half. It cannot, then, have much exceeded a million at any time before the Conquest...'

${ }^{115}$ For commentary on the difference between the ducal law of Normandy and the law of England, see O'Brien, n 45, pp 12, 20-1. See also Baker, $\mathrm{n} 59$, ch 2 re the Norman conquest.
} 
exceptional privilege, liability to war the natural state of things. The king's peace was extended to particular times and places, or conferred as a favour on particular persons.

Some time after the Conquest all these special regulations were disused: but they were replaced by a general proclamation of the 'king's peace', which was made when the community assented to the accession of the new monarch: and this first proclamation was considered to be in force during the remainder of his life, so as to bring any disturber of the public tranquillity within its penalties. ${ }^{116}$ (wording divided for ease of reference)

The asserted laws of William I ${ }^{117}$ continued to refer to the 'king's peace'. ${ }^{118}$ And that that peace (protection) covered the four main highways that traversed England, ${ }^{119}$ as in Anglo-Saxon times.

\section{(b) Coronation Charter of Henry I (1100)}

By the time of Henry I (1100-35) the 'king's peace' extended throughout the realm, his Coronation charter (published in 1100) stating:

I establish lasting peace throughout the whole of my realm and enjoin that it be maintained henceforth. ${ }^{120}$

In a sense, this was the inevitable result of William I's requirement in 1086 that all subjects acknowledged his sovereignty or overlordship - including all magnates. ${ }^{121}$ It set in place a system where the Crown became not only the source of the law, but the enforcer of it, through its courts and policing system. ${ }^{122}$

\section{(c) Laws of Henry I (c. 1113)}

The legal text, the Laws of Henry I, was probably written c. 1113. ${ }^{123}$ It distinguished between Crown pleas and those of sokes (i.e. those who had a Crown franchise to hold a court). ${ }^{124}$ As to the former, it stated:

These are the jurisdictional rights which the king of England has in his land solely and over all men, reserved through a proper ordering of peace and security (pacis ac securitatis). ${ }^{125}$

\footnotetext{
${ }^{116}$ Stephen, $\mathrm{n} 71$, vol 1, pp 60-1. He continued: 'So much importance was attached to the ceremonial act of the proclamation that even in the reign of [king] John [1199-1216], offences committed during the interregnum or period elapsing between the day of the death of the last monarch and the recognition of his successor were unpunishable in those tribunals whose authority was derived from the Crown.' See also Holdsworth, n 35, vol 2, pp 48-9.

${ }^{117}$ Robertson, n 59, p 239 'The Ten Articles of William I'. The first states: '[William I]...desires...that peace and security [pacem et securitatem] should be maintained among English and Normans.' See also Willelmi Articuli Retractati 'The decrees and legal reforms of our lord king William the Bastard, which he established in England, formerly called Britain...In the first place he desires ...that peace, security and concord, law and justice [pacem et securtitatem et concordiam] should be observed....among English and Normans...etc.' and 'We desire likewise and firmly enjoin, that all men, whom we brought with us or who have come after us, shall enjoy the benefits of protection [sub protectione et in pace nostra] throughout the whole of the aforesaid realm.'

${ }^{118}$ Ibid, p 253 where Robertson cites the (so-called) Laws of William I 'he who violates the king's peace shall pay 100 shillings as compensation in the province of Mercia...And he who, in the Danelaw, violates the king's peace shall pay £144 as compensation.'

${ }^{119}$ Ibid, p 267 'If anyone slays or assaults anyone who is travelling through the country on any of the (following) four highways, namely, Watling Street, Ermine Street, the Fosse Way, the Icknield Way, he violates the king's peace.' See also p 369 and Pollock, n 78, pp 80-1.

${ }^{120}$ Ibid, p 281. It would seem that this statement was not just a legislative platitude, but reflected the geographical extension of the Crown's judicial ambits. See also O'Brien, n 45, p 239. The peace of the king lasted only until his death. Thus, on the death of Henry I [1100-35] there was chaos. However, with Edward I (1272-1307) who was in Palestine when Henry III (1216-72) died in 1272, the king's peace was proclaimed by the magnates and from this occasion the king's death was not held as suspending the king's peace. See also CS Kenny, Outlines of Criminal Law (Cambridge UP, $1^{\text {st }}$ ed, 1902), p 131 and CA Beard, The Office of Justice of the Peace in England (AMS Press, 1967$), \mathrm{p} 15$.

${ }^{121}$ Allen, n 103, p 26 'It was an assertion of the principle, which was to be the keystone of the whole feudal system, that whatever the claims of lordship and service might be, there was only one supreme overlord and to him the transcendent fealty was due.'

${ }^{122}$ The latter, mainly, comprised the employment of frankpledge (see n 106) and hue and cry, see McBain, n 106.

${ }^{123}$ This text does not comprise a statement of the 'laws' as such (being a legal text) - it probably does reflect the legal position of that time fairly accurately. See P \& M, n 59, vol 2, p 457.

${ }^{124}$ Downer, n 42, p 109 'In the case of the soke of pleas, some of these profits belong peculiarly and exclusively to the royal treasury, some are shared by it with others, some belong to the sheriffs and royal officials in their farm, and some belong to the lords who have soke and sake.' Also "crown pleas of the king...do not belong to the sheriffs or his officials or bailiffs in their farms except by definite arrangement beforehand.'

${ }^{125}$ Here, 'peace' is used in a general and non-legal sense. See also Downer, n 42, p 201 'But there shall be true peace [pax] in respect of all men and blessed love to the honour of almighty God, by whose wisdom we have been created, by whose birth we have been exalted, by whose death we have been redeemed and by whose comfort we are made safe.'
} 
The Crown pleas cited included: (a) breach of the king's peace given by his hand or writ (i.e. handgrio); ${ }^{126}$ (b) BOTP in the king's troop [i.e. in his army]; (c) violation of the king's protection (borchbrege); (d) violation of the king's law (prevaricatio legis regie); (e) all highways; (f) all places of execution. ${ }^{127}$ Thus, it is of note that:

- By the time of Henry I, the reach of the king's 'peace' (criminal jurisdiction) included highways, forests, places of execution and BOTP in the king's army; ${ }^{128}$

- References to BOTP were, clearly, intended to cover a range of (the more serious) crimes and it was not a crime, per se. That is, it was a generic reference with any act resulting in a BOTP being a plea of the Crown; ${ }^{129}$

- Although the basic notion of the king's peace (the action taken by the king to avert a blood feud) was still reflected in the law ${ }^{130}$ this was being superceded by a simple reference to the 'king's peace' without the underlying rationale being cited. ${ }^{131}$

Beard stated that, by Henry II's time (1154-89):

the king's peace was so elastic that it was an easy matter to stretch it over causes which had hitherto belonged to the seigniorial lords. ${ }^{132}$

In particular, unemandable breaches of the king's peace (i.e. handgrio) had become felonies and they were pleas of the Crown. ${ }^{133}$

In conclusion, by the time of Henry I (1100-35) the 'king's peace' purported to extend throughout the land geographically. However, local criminal courts still administered their own 'peace'.

\section{Breach of the Peace - Glanvill (c. 1189)}

Some 70 years after the Laws of Henry I, the first text on English law appeared - Glanvill's Treatise on the Laws and Customs of the Realm of England (c. 1189). ${ }^{134}$ It stated:

\footnotetext{
${ }^{126}$ Downer, n 42, p 109. Also, p 247 'A person who breaks the king's peace [qui pacem regis fregerit] which he confers on anyone with his own hand shall, if he is seized, suffer the loss of his limbs.'

127 Ibid.

${ }^{128}$ See also Downer, n 42, p 251 'the house of the king or his court is anywhere where he may be in the land, whosoever fee or feudal holding it is.' Also, p 121 'The king's peace [pax regis] shall extend thus far from his gate, where he is in residence, in all four directions from that place, that is to say, three miles, three furlongs, the breadth of three acres, nine feet, the breadth of nine hands and of nine grains of barley. There must be much consideration and much acre to see that no one violates the king's peace [pacem regis infringat], especially in his vicinity.'

${ }^{129}$ See also Downer, n 42, p 115 where the Laws of Henry I state: 'Wherefore, because of the many molestations by evildoers it has been provided by way of a fit ordering of the peace [commode pacis dispensatio] that pleas concerning more serious charges and meriting greater punishment shall be assigned to the justice and mercy of the sovereign alone, so that more abundant pardon may be had for those seeking it and more abundant pardon for those transgressing.' Ibid, p 189 'Trial by battle shall not take place unless...the charge is one of theft or of a misdeed of this kind or concerns a breach of the king's peace [de pace regis infracta]...'. TFT Plucknett, $A$ Concise History of the Common Law ( $5^{\text {th }}$ ed, 1956), p 15 'justiciars were sent on circuit [in the time of Henry I, 1100-35] to look after the pleas of the Crown (and they soon usurped for their master immense jurisdiction by asserting that any matter which concerned the king's peace could be treated as a plea of the Crown).'

${ }^{130}$ Downer, $\mathrm{n} 42, \mathrm{p} 239$ (the Laws declare that, where a man is slain and his wergild is subsequently paid by the aggressor (slayer), 'the king's peace shall be established between them').

${ }^{131}$ Baker, n 59, p 501 'when the blood-feud system went into disuse and the Crown assumed the power to punish those who broke the 'king's peace'. 'Also, p 502 'Associating serious criminal offences with the king's peace provided a justification for bringing all criminal punishment within the purview of the common law.' The exception was the right to take and execute a person with no (or almost no or a scanty trial) which had ended by about the $14^{\text {th }}$ century.

${ }_{132}$ Beard, n 120, pp 15-6 citing P \& M, n 59, vol 2, p 464.

${ }^{133}$ By the time of Henry II as Allen noted, n 103, p 31 'those deadly sins which anciently were breaches of the king's own peace or grith remain heinous, but take on the character of felony; and felonies become pleas of the Crown, for every felony is an offence committed nequitur et in pace domini regis...the scope of felony steadily grew until by the end of the thirteenth century all the more grevious misdeeds had become pleas of the Crown...The groundwork which he [Henry II] laid [principally in the Assize of Clarendon 1166] for the pleas of the Crown remained, and still remains, the foundation of our criminal law in all subsequent ages... We have now reached a point at which we can say that the criminal law of the realm is well grounded upon the King's Peace...' Baker, n 59, p 502 'If the wrong was particularly heinous, it was 'unemendable' and the wrongdoer suffered judgment to lose everything that he had: his life, his lands, and his personal goods. Wrongs of this kind were called 'felonies', from an old French word (meaning wicked or treacherous) which seems to have originated in the feudal context. A felony was such an act of wickedness that it destroyed the bond between lord and man, so that the tenant's land was forfeited to the lord.' It was also said that Henry I (1100-35), in 1008, ordered felons to be hanged instead of their being able to settle by paying a fine. T Blount, $A$ Law Dictionary ( $3^{\text {rd }}$ ed, 1717)(felony). This would have affected the tariff system which prevailed until then.

${ }^{134}$ Glanvill, The Treatise on the Laws and Customs of the Realm of England (c. 1189)(Nelson, 1965). Book 14 dealt with criminal pleas and discussed, inter alia, (a) treason; (b) concealment of treasure trove; (c) homicide; (d) arson; (e) arson; (f) robbery; (g) rape; (h) falsifying
} 
Pleas are either criminal or civil. Some criminal pleas belong to the crown of the lord king, and some to the sheriffs of counties.

And, after listing pleas of the Crown (treason, arson, robbery etc.) Glanvill noted:

If lords [of the manor] fail to do justice, then sheriffs also have jurisdiction over brawling, beatings, and even wounding, unless the accuser states in his claim that there has been a [BOTP] of the lord king (de pace domini regis infracta). ${ }^{135}$

Thus, Glanvill was indicating that all criminal offences were not within the 'king's peace' (Crown pleas), but that the plea could be brought into the former by being asserted. As to 'king's peace', Milsom noted:

Glanvill lists the king's peace broken among the pleas of the crown ${ }^{136}$ and in his time it was a serious matter. He might give his peace to his servants, his favourites, those who might pay for the privilege. It might be widened at the great feasts of the church, or extended to all persons in certain places, wherever the king was, the king's highway. It was in short a personal thing and not a governmental abstraction; and for example, it died with the king. It follows that what made a breach of the king's peace was not the intrinsic quality of the act, but the person, the place, even the season. The same act, or one more outrageous, might in other circumstances be a breach only of a lesser lord's peace or the sheriff's; and proceedings would then be in the lord's or the county court. ${ }^{137}$

In 1195, Archbishop Hubert issued a proclamation for the preservation of the peace in which all men were required to give frankpledge (a 'peace pledge' or pledge to keep the peace) and to assist in the hue and cry, which was the frankpledge in action. ${ }^{138}$ The Proclamation of 1195 included the following:

That all subjects of the kingdom of England shall, to the best of their power, keep the peace of their lord the king; that they shall not be thieves or robbers, not yet harbourers of them, nor shall in any way abet them; and that whenever they shall be able to know of any malefactors of that character, they shall, to the best of their ability, endeavour to take them, and deliver them up to the sheriffs... and if they shall not be able to arrest them they shall give notice of them, whoever they may be, to the bailiffs of our lord the king. ${ }^{139}$ (italics supplied)

Reference to the hue and cry is important since, here, the obligation to keep the peace covered not just offences of violence such as murder, robbery, riot etc, but also theft (which in Glanvill's time was not a Crown plea) and forgery. ${ }^{140}$ Thus, 'breach of the peace' was becoming elastic in terms of the offences which it covered as well as its jurisdictional reach (with the king's court assuming a greater and greater jurisdiction over criminal matters).

In conclusion, as the 'king's peace' widened in terms of geographical ambit and the crimes which the king's courts were prepared to handle ${ }^{141}$ - it became synonymous with the Crown's criminal jurisdiction.

\section{Breach of the Peace: Bracton (c. 1240)}

\section{(a) Bracton - Breach of the King's Peace}

Bracton, in his On the Laws and Customs of England (c.1240), referred to 'peace' and to BOTP. ${ }^{142}$ In respect

\footnotetext{
135 Ibid, p 4. SFC Milsom, Historical Foundations of the Common Law ( $2^{\text {nd }}$ ed, 1981), p 286 'We should think not of peace in our sense, an antonym of violence, but of protection, law. It was not a mere abstraction but belonged to a person, usually the king or a lord. Glanvill makes it clear, in three words which have been overlooked, that for him the primary jurisdiction over trespass was that of lords. Beatings and such come to the sheriff only per defectum dominorum, and not even then if a breach of the king's peace is alleged...'.

136 This wording intimates that BOTP was a distinct crime. However, this is not so.

${ }^{137}$ Milsom, n 135, p 287.

${ }^{138}$ Beard, $\mathrm{n} 120$, pp 17-8. See also McBain, n 106. Both frankpledge and hue and cry derived from Anglo-Saxon times.

${ }^{139}$ See HT Riley (trans), The Annals of Roger of Hoveden, Vol 2 Pt 2 AD 1192 to 1201 (facsimile rep by Llanerch Publishers), pp 367-8. See also McBain, $\mathrm{n}$ 106. This obligation to participate in the hue and cry was encapsulated, nearly 100 years later, into the Statute of Westminster 1275 (3 Edw I) c 9: 'That all generally be ready and apparelled, at the commandment and summons of sheriffs, and at the cry of the country [crie de pays], to [sue] and arrest felons, when any need is, as well within the franchise as without and they that will not do so, and thereof be attainted, shall make a grevious fine to the king.' See also the statute, Of the Office of Coroner (De Officio Coronator) 4 Edw 1 (1276, rep 1887). It provided that: 'huy shall be levied for all [murders, burglaries and for men slain, or in peril to be slain] as otherwise is used in England; and all shall follow the huy and [cry][as near as can be] and he that does not, and is convict thereupon, shall be attached to be before the justice [of the goal etc]' (spelling modernized).

${ }^{140} \mathrm{P} \& \mathrm{M}, \mathrm{n} 59$, vol 2, p 580.

${ }^{141}$ Baker, n 59, p 15 'The king's law was not yet universal...Royal justice...steadily gained ground over the old 'communal' institutions, not because of new constitutional theories, but because it suited both Crown and litigants that it should do so.'

${ }^{142}$ See $\mathrm{n} 42$. Bracton is online so such references may be elicited by means of a word search.
} 
of the latter, Bracton's references to these could as easily have been to the 'king's criminal law' as may be seen from the following citations (italics supplied):

$\circ \quad$ Justices at Eyre. When explaining to persons the purpose of the eyre, Bracton cited the words of another judge (Martin of Pateshull): 'First of all, of the king's peace and justice and the breaches thereof by murderers, robbers and burglars...' Also, And let him [the judge] declare that the king orders all his lieges...to lend effective and diligent counsel and aid for the preservation of his peace and justice. In effect, these references to the 'king's peace and justice' and to the 'his peace and justice' were to the Crown's criminal law; ${ }^{143}$

- Qualifications of the Jury. At eyre, the jury was to be 12 men 'not under suspicion of breach of the peace' (de pace infracta). That is, men not suspected of committing crimes punishable in the king's courts;

○ Homicide. This crime is described as: 'partly concerns the king, whose peace is broken, and partly the private individual who is slain wickedly and in breach of the king's peace'. That is, homicide is a crime (the peace being broken) which is punishable by the king in his courts;

- Wounding. Wounding, when cognisable in the king's court, is in 'breach of the peace' and must be pleaded as such - as in the case of every injuria or trespass. ${ }^{144}$ That is, wounding is a crime (the peace being broken) punishable by the king in his courts, when the BOTP is so described;

- Outlaws. An outlaw is described as one 'disobedient to the law' (inobediens legi secundum legem terrae) who must 'return to the peace' (quod redeat ad pacem). ${ }^{145}$ That is, the outlaw must re-subject himself to the Crown's criminal law;

- Thieves. A thief who flees to a church for sanctuary may be taken out 'if he refuses to come to the king's peace'. That is, subject himself to the king's criminal law (the peace); ${ }^{146}$

- Killing. On a killing the king may proceed to an inquest 'for the preservation of his peace. ${ }^{147}$ That is, the Crown's criminal law (peace) must be preserved.

\section{(b) Bracton - Breach of the Lord's or Sheriff's Peace}

In contradistinction to the 'king's peace', Bracton cited local criminal courts which exercised their 'peace' (criminal jurisdiction), viz the:

- sheriff's county court ${ }^{148}$ (but not the sheriff's tourn which was a king's court); ${ }^{149}$

- courts leet of barons; ${ }^{150}$ and

- other seigniorial courts (such as duchy, palatine or corporation courts). ${ }^{151}$

\footnotetext{
${ }^{143}$ Bracton, n 42, vol 2, p 327.

${ }^{144}$ Ibid, p 345. Also, p 398 'An appeal also falls if no mention is made of the king's peace, only of the justice's peace or the sheriff's.'

145 Ibid, p 352.

${ }^{146}$ Ibid, p 382 'There are some who when they ought to be arrested flee to a church... They then have no alternative but to come to the king's peace...'

${ }^{147}$ Ibid, p 402. Also, p 403 'when the king, to preserve his peace, brings suit against an appellee...' Also, p 407 'since a felony may lie concealed, let the king, if he so wishes make inquiry to preserve his peace...'

${ }^{148}$ Ibid, p 436 ' These pleas belong to sheriffs in the county court. He may have cognizance of affrays, woundings, beatings and the like, on the default of lords, unless the complainant adds 'in breach of the king's peace 'or assigns felony; after that the sheriff must not intermeddle since this concerns the person of the king and his crown.' The removal of sheriffs from pleas of the Crown was completed by Magna Carta 1215. Baker, n 59, p 23 'the removal from sheriffs of pleas of the Crown, a process which began de facto with the eyres and was completed de jure by an absolute prohibition in Magna Carta.' See also Holdsworth, n 35, vol 1, p 13.

${ }^{149}$ Blount, $\mathrm{n} 133$ (turn) 'It is a court of record in all things that pertain to it; it is the king's leet through all the county, and the sheriff is judge, and the court is incident to his office.' The sheriff's tourn (or turn)( abolished in 1887) happened twice a year through the hundreds (and wapentakes), in which the sheriff judged minor crimes and took frankpledge etc, all in his capacity as an officer of the Crown. See Bracton, $\mathrm{n} 42$, vol 2, p 437. Also, FM Nichols (ed), Britton (John Byrne \& Co, 1901), ch 30 and Baker, n 59, pp 24-5.

${ }^{150}$ Most lords of manors had a franchise (liberty) from the Crown which enabled them to hold a criminal court (a court leet or lawday) which dealt with minor criminal offences. See also Baker, $\mathrm{n} 59$, pp 26-7. The court leet was derived out of the sheriff's tourn (and subject to it) with the steward of the court as judge. See e.g. W Sheppard, The Court Keepers Guide (1654), p 4.

${ }^{151}$ For the palatinates, see GS McBain, Abolishing some more Obsolete Crown Prerogatives (2011) Liverpool LR, vol 32, no 1, p 83-6. The only palatinates which exist, today, comprise those of: Chester, Durham and Lancaster. However, they no longer have a distinct criminal jurisdiction (including the right to appoint their own judges or JP's, the ability to pardon crimes, writs and indictments running in the name of
} 
These local courts only dealt with minor offences and only damages could be imposed. ${ }^{152}$ Further, their jurisdiction could be obviated by alleging a BOTP ${ }^{153}$ since - where it applied - no lord of a manor court (or the sheriff in a county court) could intermeddle. ${ }^{154}$ Thus, Bracton noted that they could not interfere with felony, since:

life and members are placed in jeopardy because no one may judge as to that except the king. ${ }^{155}$

As for the word 'peace', as well as to describe an absence of public disturbance:

- Bracton used it for the king pardoning a person, ${ }^{156}$ such that he became 'law worthy' again (i.e. restored to the peace). ${ }^{157}$ Being an 'inlaw' such a person could remain 'in the realm in the king's peace' - unlike an outlaw who had to abjure the realm; ${ }^{158}$

- Bracton also used it an almost universal sense of the criminal law - the "king...ought to safeguard the peace for the security of all. ${ }^{159}$

Finally, Bracton asserted the transcendent principle (which still applies today) that criminal justice (including the right to hold a court) derived from the king, stating:

Justice belongs to no one except the king, nor does imprisonment, nor will anyone have his court thereof unless he enjoys a special liberty from the king himself... ${ }^{160}$

For their part, Pollock \& Maitland refer to a typical accusation of wounding or robbery in Bracton's day (c.1240) (which appeal referred to the victim being 'in the peace of God and our lord the king') and state:

The allusion to the peace of God may be an echo of the treuga Dei which had at one time been enforced in Normandy, if not in England, and which, when it had attained its largest scope, comprehended many holy seasons and a long half of every week: but we do not know that it was of much importance in this country. Be this as it may, the words about the king's peace have had a definite meaning; they point to a breach of the king's grio or mund, a crime which at all events deserves the heavy wite of a hundred shillings, and which, when coupled with homicide, has been unamendable.

The manner in which the king's grio or mund has been extending itself until it begins to comprehend all places within the realm, all persons who are not outlaws and every time which is not an interregnum, we must not describe at any length. When the Conqueror [i.e. William I] declared that all the men who he had brought hither were within his peace, he was spreading abroad his mund. ${ }^{161}$....Already in Glanvill's day it is understood that an accuser can place an assault outside the competence of the local courts by some four or five words about the king's peace. ${ }^{162}$

\footnotetext{
their peace etc). Nor do the Cinque Ports or the duchies of Lancaster (created 1351) or Cornwall (created 1337). Nor do any corporations - such as the Corporation of the City of London. Thus, they are not discussed further. For these, see GS McBain, The Charters of the Cinque Ports Are they Still Needed? (2013) Review of European Studies, vol 5, no 2, pp 90-126, GS McBain, Time to Abolish the Duchy of Lancaster (2013) Review of European Studies, vol 5, no 4, pp 172-93, GS McBain, Time to Abolish the Duchy of Cornwall? (2013) Review of European Studies, vol 5, no 5, pp 40-58. For the position re palatinates in 1765, see W Blackstone, Commentaries on the Laws of England (Oxford, Clarendon Press, $1^{\text {st }}$ ed, 1765-9, University of Chicago Press rep 1979), vol 1, pp 113-5. As for the Welsh Marcher Lords, any prerogatives they may have had, re criminal jurisdiction, ended in 1536. See AC Reeves, The Marcher Lords (1983).

${ }^{152}$ Bracton, $\mathrm{n} 42, \mathrm{p} 359^{\prime}$ '....it is otherwise of the sheriff's peace [in the county court] and elsewhere where nothing except damages are recovered... where nothing other than pecuniary punishment follows.'

${ }^{153} \mathrm{Ibid}, \mathrm{p} 402$ (form of an appeal) 'A was present in the county court when the aforesaid B threatened his same brother, so that the king's peace was sought by him in the said county court and later given him in the king's court.'

${ }^{154}$ Ibid, p 436

${ }^{155}$ Ibid, pp 411-2.

${ }^{156}$ Ibid, p 369 'Let the lord king's letters patent testifying that he has granted him his peace (pacem suam) be drawn in this form 'A writ addressed to all bailiffs to the effect that the lord king pardons a flight and outlawry occurring in his reign.' Also (in the writ) 'we will and order that the said $[\mathrm{A}]$ have our steadfast peace therein...'

${ }^{157}$ Blount, n 133, (inlaugh)'signifies him that is (sub lege) in some frankpledge, not outlawed.' In the case of an outlaw, see e.g. Bracton, vol 2, p 373-5.

${ }^{158}$ See, for example, Bracton, $\mathrm{n} 42$, vol 2, p 377 'the inlaw may then remain in the realm in the king's peace.' The outlaw was also called the 'friendless' man. Blount, n 133 (friendless man) 'Frendles man, was the old Saxon word for him whom we call an outlaw; the reason is, because he was, upon his exclusion from the king's peace and protection, denied all help of friends after certain days.'

${ }^{159}$ Bracton, $\mathrm{n}$ 42, vol 2, p 383.

${ }^{160}$ Ibid, p 412. Cf. P \& M, n 59, vol 1, p 528 and Allen, n 103, p 8, fn 4.

${ }^{161} \mathrm{P} \& \mathrm{M}, \mathrm{n} 59$, vol 2, p 464. They cite the coronation oath of Henry I (see text to $\mathrm{n} 120$ ) mis-stating it as being that of Henry II.

${ }^{162}$ Ibid. They cite Glanvill, see p 4 ('unless there has been a [BOTP] of the lord king').
} 
But the very ease with which the king's peace spread itself until it had become an all-embracing atmosphere prevented a mere breach of that peace form being permanently conceived as a crime of the highest order. Every action of trespass in the king's court supposes such a breach; every convicted defendant in such an action must go to prison unless he pays a fine to which the law sets no limits; and yet the day for nominal trespasses is approaching; a breach of the king's peace may do no perceptible harm, and accusations of that offence will be freely thrown about in actions which are fast becoming merely civil actions. ${ }^{163}$ (wording divided for ease of reference)

In conclusion, by Bracton's time, the king's peace and the king's criminal law were one and the same. Further, it was asserted that the local criminal courts were operating by way of franchise.

\section{Britton (c. 1290) \& Fleta (c. 1290)}

Britton (writing c.1290) did not deal with BOTP in any detail. Fleta (writing c 1290), when considering matters justices of the eyre dealt with - after referring to more serious crimes which touched the king's person (such as various treasons) - indicated that BOTP included lesser crimes. ${ }^{164}$ Fleta also referred to keeping the peace (de pacis conservacione) in the context of hue and cry ${ }^{165}$ as well as for BOTP to be pleaded since:

in no court, save before the king's justices, may any action be brought in which mention is made of breach of the king's peace, except an appeal before the coroners and sheriff. It is possible, however, to omit the king's peace and to insert the peace of the lord or of the sheriff. ${ }^{166}$

In conclusion, by the end of the $13^{\text {th }}$ century, the king's peace had grown into a common right. ${ }^{167}$ Further, church peace and the individual's peace had been, effectively, subsumed into the same.

\section{Breach of the Peace: 1290-1538}

In this period, there was little change save that the 'king's peace' became more and more associated with pleas of the Crown ${ }^{168}$ as local jurisdiction declined. ${ }^{169}$

- The latter was furthered by an Act of $1535^{170}$ in which the judicial powers of counties palatine (Chester, Durham, Lancaster, Pembroke and Hexam) were abridged. ${ }^{171}$ It provided that, in the counties palatine, all writs, indictments and processes were to be in the king's name; ${ }^{172}$

- By this time, the courts leets were also in decline. ${ }^{173}$

\footnotetext{
163 Ibid.

${ }^{164}$ Fleta, Selden Society ('SS') vol 72, p 46 'But there are also certain crimes that are in a degree less because, although they touch the king in part, because his peace is broken [pacem suam infractam], they touch as well, in part, private persons, against whom the offence is committed, such as those of homicides, accidental and wilful; of burglars, thieves, robbers and their harbourers; of those who beat, wound, are insolent and disturb the peace [et paci rebellis]; of those who commit arson by night or by day and those who wickedly commit violent assaults in time of peace [tempore pacis]; of ravishers and abductors of virgins and nuns and of matrons living chastely; of imprisoners and those having or making prisons; of outlaws and their harbourers.'

${ }^{165}$ Ibid, p 61'In order that all men may enjoy sure peace (pace), it has been enacted [Statute of Westminster 1275, ch 9, see $\mathrm{n}$ 139] that all to be ready, at the order of the sheriff and at the cry of the countryside, to pursue and arrest felons, when necessity arises, both within the franchise and without, and the king will deal grievously with him who does not do this.'

${ }^{166}$ Ibid, p 101. See also Pollock, n 78, p 90 'to give the king's courts jurisdiction of a plea of trespass it was needful to insert into the writ the words vi et armis, which imported a breach of the peace; and it was usual, if not necessary, to add expressly the words contra pacem nostram.' See also Harding, n 73, pp 76-7.

${ }^{167}$ Pollock, n 78, p 88. Also, 'the writ de securitate pacis made it clear beyond cavil that the king's peace was now, by the common law, the right of every lawful man.'

${ }^{168}$ Milsom, n 135, p 404 'Pleas of the crown were originally matters in which the crown had an interest, as opposed to common pleas; and they included 'civil' claims involving royal rights. But these dropped away, so that until the nineteenth century information about what we call the criminal law was to be sought in books entitled 'pleas of the crown.' Pleas of the crown were either felonies, in which the royal interest was in a forfeiture of property, or trespasses against the king's peace for which neither life nor property was forfeit; but the offender was imprisoned until he redeemed himself, made fine with the king..'

${ }^{169}$ Ibid, p 405 'Local offences died with local justice, and were simply lost...'

17027 Hen 8 c 24 (1535)(rep).

171 That of Pembroke was later abolished in 1535 and that of Hexam in 1572, see Blackstone, n 151, vol 1, p 114. This Act did not affect counties corporate (London, York, Bristol etc). Nor the Isle of Ely (which had jura regalia but was not a county palatine), the bishop having criminal jurisdiction until the Liberty of Ely Act 1837.

${ }^{172}$ Ibid, s 3. As Crabb, n 59, p 441 noted 'All writs and indictments were to allege facts as done against the king's peace, and not as formerly in a court-leet, contra pacem domini, or in the tourn, contra pacem vicecomitis; but they might be tested in the name of the person who had the county palatine or franchise.'
} 
Further, the concept of the 'king's peace' applied throughout the realm. For example, an Act of 1488 in the reign of Henry VII (1485-1509) observed:

The king considereth that a great part of the wealth and prosperity of the land standeth in that, that his subjects may live in surety under his peace in their bodies and goods... ${ }^{174}$ (italics supplied)

Finally, as Reeves noted:

The peace, in the most extensive sense of the word, took in, perhaps, the whole of the criminal law; ${ }^{175}$ and as most offences were said to be against the peace, all those magistrates who had authority to take cognizance of such offences, might be considered as a sort of guardians of the peace ex officio... ${ }^{176}$

A similar wide ranging view of the 'peace' was provided by Fitzherbert in his New Boke of Justices of the Peas (1538). It stated:

the peace is none other thing in effect, but amity and confidence had and [annexed] among the king's subjects, and he that breaks this amity or confidence, breaks the peace.

In conclusion, by the time of Henry VII, the 'king's peace' applied throughout the realm. Further, it covered crimes both in the king's courts and those operating by way of franchise.

\section{Lambard (1581) \& Pulton (1609)}

\section{(a) Lambard - Eirenarcha}

Lambard - in his Eirenarcha (or the Office of the Justice of Peace)(1581) ${ }^{178}$ - stated, as to the 'signification of the worde peace':

Of the latin word pax, the Normans framed their paix, and we out of that, our peace: which name has sundry significations in the holy scripture: for there is an inward, and an outward peace...the outward peace...is of two sorts...the one is opposed (or set) against all manner of striving and contention, whether it be in countenance, gesture, word, or work...The other is only an abstinence from actual force and offer of violence, and is rather contrary to arma, praelium, and bellum [arms, combat, war] (which can not be without force, or arms) that is to say vis, pugna or certamen ...[force, battle, strife]

The law of our realm likewise, uses the word peace diversely, but yet so, as it is altogether occupied about these outward peaces... Sometimes therefore, the word peace is taken for protection, or defence as where $\mathrm{M}[\mathrm{r}]$ Bracton calls writs of protection, or brevia de pace: Sometimes (as it seems to me) it is taken for rights, privileges and liberties, as in the oath of the Queen at her coronation, she swears servare ecclesiae dei, cleri et populi pacem ex integro: the meaning whereof is (as I suppose) that she will maintain each degree and estate of her subjects, as well ecclesiastical as temporal (for populus comprehends all the laity) according to their several customs, laws and privileges. And sometimes it is taken for a withholding (or abstinence) from that injurious force or violence, whereof I spoke before. And this is it that is most commonly understood by the word peace in our law: and for the maintenance

\footnotetext{
${ }^{173}$ Holdsworth, n 35, vol 1, p 136 'courts leet...tended to decline in power and importance from the sixteenth century onwards, because they were superceded by the newer and more effective machinery of justices of the peace.'

1744 Hen 7 c 12 (rep).

${ }^{175}$ As to persons who were said to be outside the law, a man attainted of praemunire was not in the king's peace and, until 5 Eliz 1 (1562), it was not murder to kill him. See Kenny, n 120, p 131. As for outlaws (those who bore the wolf's head) E Coke, Institutes of the Laws of England (W Clarke \& Sons, London, last ed, 1824, which is cited), vol 1, 128b noted that, at the beginning of the reign of Edward III (1327-77) it was resolved by the judges, that it should not be lawful for any man, but the sheriff only (having a lawful warrant) to put to death an outlaw (it was murder otherwise). By the time of Hale any non-judicial killing was murder, see n 198, vol 1, p 497 'it is not lawful for any man to take away the life of another, tho a great malefactor, without evident necessity, whereof before, or without due process of law for the deliberate uncompelled judicial killing of a person attaint of treason, felony, or murder, or in a praemunire, tho upon the score of their being such, is murder.' Outlawry was abolished in 1938. Aliens (including enemy aliens) are under the 'king's peace.' (i.e. subject to the criminal law).

176 J Reeves, History of the English Law (2 ${ }^{\text {nd }}$ ed, 1787, rep Rothmans, 1969), vol 2, pp 468-9. He continued 'such were the king's justices, inferior judges, and ministers of justice, as sheriffs, constables, tythingmen, headboroughs, and the like; all these were ex officio guardians and conservators of the peace.'

177 A Fitzherbert, The New Boke of Justices of the Peas (London, 1538, rep Professional Books, 1972), fo 6. This text was a translation of L'Office et Auctoryte des Justyces de Peas, printed earlier that year. Fitzherbert's text was later edited by Richard Crompton, see R Crompton, L'Office et Auchtoritie de Justices de Peace (1584, rep Professional Books).

${ }^{178}$ W Lambard, Eirenarcha (1581) This has been reprinted by the Law Book Exchange. The last edition was in 1619. For development of the role of JP's, see BH Putnam, Proceedings before the Justices of the Peace in the Fourteenth and Fifteenth Centuries (Ames Foundation, 1938).
} 
hereof chiefly, were these wardens and justices of the peace first made and appointed. ${ }^{179}$ (italics supplied and spelling modernised)

Lambard also asserted that JP's were ordained 'to suppress injurious force and violence, moved against the person, his goods or possessions. ${ }^{180}$ Lambard cited a writ issued in 1327 of the reign of Edward III (1327-77) which indicated that none should presume to infringe, or violate, 'our peace' ${ }^{181}$ and opined that the 'peace' the king was referring to was not a 'uniting of minds, but a restraining of hands ${ }^{182}$ and

therefore, I conclude, that this furious gesture and beastly force of body, or hands (and not every contention, suit and disagreement of minds) is the proper subject and matter about which the office of the justice of the peace is to be exercised.

In the same vein, Lambard noted that:

menacings, affrays, assaults, injurious and violent handlings and misentreatings [mistreatings] of the person, batteries, malicious strikings, etc

were BOTP and resulted in the forfeiture of a recognisance posted for the keeping of the peace. ${ }^{183}$

\section{(b) Lambard - Duties of Constables}

In his work on Dueties of Constables, Borsholders, Tything-men and such other lowe and lay Ministers of the Peace $\left(1^{\text {st }}\right.$ edition, 1582. I cite from the $8^{\text {th }}$ edition in 1599) Lambard stated:

The conservation (or maintenance) of the peace, stands in three things, that is to say: first, in foreseeing that nothing be done, that tends either directly, or by means, to the breach of the peace: secondly, in quieting or pacifying those that are occupied in the breach of the peace: and thirdly, in punishing such as have already broken the peace. ...by the breach of the peace, is understood, not only that fighting, which we commonly call the breach of the peace, but also that every murder, rape, manslaughter, and felony whatsoever, and every affraying (or putting in fear) of the Queen's people, whether it be by unlawful wearing of armour, or by assembly of people to do any unlawful act, are taken to be disturbances of the peace... ${ }^{184}$

\section{(c) Pulton}

In 1609, there was issued the first edition of Pulton's De Pace Regis et Regni (1609). ${ }^{185}$ Its title is indicative that the 'king's peace' (pace regis) was now the same as our conception of the criminal law since this text purported to cover all crimes. Further, in the context of the hue and cry, Pulton stated:

But the peace of the realm has been so precious to all ages; and treasons, felonies, assaults, batteries and other forcible violences and offences so obvious, that the laws and statutes of the realm, and the wisdom of our forefathers have been made and appointed (besides the magistrates and officers before mentioned) all sorts of able persons, in some sort, and to some purposes, preservers of the peace; intending that as all the members of the common weal, do taste sweet comfort, and pleasant repose by the benefit of peace, so they should be all partakers, when need requires of the pains to maintain and continue the same peace, and to punish the transgressors thereof. ${ }^{186}$ (spelling modernising for ease of reference)

\footnotetext{
${ }^{179}$ Lambard, n 178, pp 4-7. What oaths Elizabeth I (1558-1603) gave at her coronation is not known. See JR Planche, Regal Records (1838), p 42. However, it was likely similar to that of Henry VII (1485-1509). See GS McBain, The Religion of the Queen - Time for Change. (2011) Queensland LR, p 41 ('You shall keep after your strength and power to the church of God to the clergy and the people holy peace and godly concord.').

${ }^{180}$ Ibid, p 7.

${ }^{181}$ Ibid, pp 8-9 (ne quis dictam pacem nostrum infringere seu violare praesumat).

${ }^{182}$ Lambard cited Bracton on vis (force). Also the Statute of Westminster 1275 'Let the peace of the land be maintained in all points, and common right be done to all, as well poor as rich.' Also, 1 Ric 2 c 2 (1377) (rep) 'Let the peace be well and truly kept, that the king's subjects may safely go, come and abide according to the law of the realm and that justice and right be indifferently ministered to every subject.' Lambard also referred to statutes of 2 Ric 2 c 4 (1378)(rep), 1 Hen 4 c 1(1399)(rep) and 7 Hen 4 c 1 (1405)(rep). See also the meaning of the commission of the peace, Lambard, n 178, p 50.

${ }^{183}$ Lambard, n 178, p 135.

${ }^{184}$ Lambard, Dueties of Constables, Borsholders, Tything-men and such other lowe and lay Ministers of the Peace ( $8^{\text {th }}$ ed, 1599), pp 11-2 (see also 1640 ed, pp 10-1).

${ }^{185}$ F Pulton, De Pace Regis et Regni (printed for the Companie of Stationers, 1609). The last edition (4 ${ }^{\text {th }}$ ed) was in 1623 . This has been reprinted by the Law Book Exchange.

${ }^{186}$ Pulton, n 185, p 23. See also p 11 'He is lawfully imprisoned who is found by verdict, or by his own confession convicted for any offence done vi et armis and against the king's peace: for the law hath ordained that all things shall be done, and all suits prosecuted between one
} 
Here, reference to the 'criminal law' could be suitably substituted for reference to the 'peace.'

\section{In conclusion, Pulton treated the 'King's peace' the same as a reference to the criminal law.}

\section{Dalton (1619), Coke (1641) \& Hale (c. 1650)}

Dalton, The Countrey Justice, ${ }^{187}$ was a popular work from when it was first published in 1618 until the final edition in 1746 (it was superseded by Hawkins (see 12)). In respect of the meaning of 'peace', Dalton stated:

Peace in effect (says Mr Fitzherbert) ${ }^{188}$ is the amity, confidence, and quiet that is between men, and he that breaks this amity or quiet, breaks the peace. Yet peace (in our law) most commonly is taken for an abstinence from actual and injurious force, and offer of violence; and so is rather a restraining of hands, than a uniting of minds, and for the maintenance of this peace chiefly, were the justices peace first made.

The breach of this peace seems to be any injurious force or violence moved against the person of another, his goods, lands, or other possessions, whether it be by threatening words, or by furious gesture or force of the body, or any other force used in terrorem populi. (spelling modernised and wording divided for ease of reference)

The later wording - likely taken from Lambard (see 10) - might seem to restrict BOTP to crimes of violence. However, it seems clear Dalton believed that it included all the criminal work undertaken by JP's ${ }^{189}$ since he also stated:

The office of the justice of peace is principally to be exercised to the suppressing of such injurious and unlawful force or violence; and yet (the commission of the peace being pro bono pacis, ac pro conservatione eiusdem, et pro quieto regimine et gubernatione populi) [for the good of peace and for the conservation of the same and for the quiet government of the people] I see not why the justices of peace should be restrained from preventing and repressing such other offences, misbehaviours, and deceipts, as may break the amity, quiet, and good government of the people, and whereof discords, and so breaches of the peace do often arise (though there appear neither force nor violence in the offence it self) as libellings, cosinages, and such other offences: vide tit good behaviour. ${ }^{190}$

Dalton also referred to the primary role of the sovereign in conserving the peace:

The common laws of this realm of England...even from their beginning, have continued a special care, for the conservation of the peace of this land and to that purpose, at the common law (long before justices of the peace were made) there were sundry persons to whose charge the maintenance of the peace was recommended, and who with their other offices had (and yet still have) the conservation of the peace annexed to their charges, as a thing incident to, and inseperable from their said offices, and yet nevertheless they were and are called by the names of their offices only, the conservators of the peace being included therein.

First the king's majesty (by his dignity royal) is the principal conservator of the peace within his dominions (and is capitalis iusticiarius angliae) [chief justice of England ] in whose hands at the beginning, the administration of all justice first was, and afterwards by and from him only was this authority derived and given to others... ${ }^{191}$ (wording divided for ease of reference)

member of the common weal and an other with all tranquillity and quietness, and he that doth any thing in perturbation of that tranquillity, breaks the king's peace, and so shall be committed to prison, as a disturber of the peace...(italics supplied and spelling modernising for ease of reference).

${ }^{187}$ M Dalton, The Countrey Justice (Societie of Stationers, $1^{\text {st }}$ ed, 1618, $2^{\text {nd }}$ ed, 1619, last ed, 1746). The first edition has been reprinted by the Law Book Exchange. The second edition is cited here, since the first was corrected.

${ }^{188}$ Ibid, p 7. Dalton referred to Fitzherbert (see text to $n$ 177).

189 Also, when analyzing the Commission of JP's (see the latin version, pp 13-5) Dalton considered a wide range of crimes which he asserted were 'against the peace.' Dalton, n 187, p 16 'The first assignavimus (or first part) of the commission does give power to any one [JP] (more or all) to keep and cause to be kept the peace, and all ordinances and statutes made for the conservation of the peace, and for the quiet government of the people: as namely, the statutes made for hue and cry after felons; and the statutes made against murderers, robbers, felons, nightwalkers, affrayers, armour worn in terrorem, riots, forcible entries, and all other force and violence; all which be directly against the peace...'. The wording in the final edition in 1746 was very similar, see Dalton, n 187 (1746 ed), p 7.

${ }^{190}$ Ibid, p 7. Dalton also stated: 'The conservation of this peace (and therein care of the justice of peace) consists in three things, viz. 1. In preventing the [ВОТP] (wisely forseeing and repressing the beginnings thereof) by taking surety for the keeping of it, or for the good behaviour of the offenders, as the case shall require. 2 In pacifying such as are in breaking of the peace...In punishing (according to law) such as have broken the peace.'

${ }^{191}$ Dalton, $\mathrm{n} 187, \mathrm{p} 1$. The wording in the final edition in 1746 was very similar, see Dalton (1746 ed), p 1. 
The 'others' referred to in the last line, Dalton held to include judges ${ }^{192}$ as well as the stewards of tourns and leets ${ }^{193}$ all of whom were responsible for keeping the peace. ${ }^{194}$ In respect of Coke and Hale, the position may be stated shortly:

- Coke, in the fourth volume of his Institutes of the Laws of England ${ }^{195}$ (published in 1641) discussed the role of JP's only briefly since he considered that Fitzherbert and Lambard had done so sufficiently. ${ }^{196}$ He did not discuss 'peace' or BOTP in any detail $;{ }^{197}$

- Hale, in his Pleas of the Crown ${ }^{198}$ (written c. 1650), after referring to treasons and felonies, referred to 'offences of an inferiour nature'. These were reducible to three kinds viz. 'breaches of public peace, deceipts and cozenage and nuisances. ${ }^{, 199}$ In the case of the first reference, Hale referred to affrays, riots, forcible entries, barretries and riding armed. ${ }^{200}$ This might suggest that BOTP was restricted only to these. However, it is important to remember that this text is more in the nature of a notebook than a legal text ${ }^{201}$ and it is incomplete. To the extent that it concludes that BOTP is so restricted it cited no authority and the history of BOTP prior to his text points to a contrary conclusion.

In conclusion, Dalton - like Pulton - had a fairly expansive notion of the concept of BOTP.

\section{Hawkins (1716-21), Burn (1755) \& Blackstone (1765-9)}

\section{(a) Hawkins}

In the first edition of his treatise on the Pleas of the Crown in 1716-21(a publication which continued until 1824)

${ }^{202}$ Hawkins discussed capital offences (treasons and felonies). He then stated:

Inferior offences more immediately against the subject, not capital, either amount to an actual disturbance of the peace, or do not. ${ }^{203}$

As to:

- those which amounted to an 'actual disturbance of the peace'. Hawkins referred to: assaults and batteries, affrays, forcible entries and detainers, riots, routs and unlawful assemblies; ${ }^{204}$

- those which did not amount to an 'actual disturbance of the peace'. Hawkins referred to offences committed by: (a) public officers (such as neglect or breach of duty, bribery and extortion), ${ }^{205}$ (b)

\footnotetext{
${ }^{192}$ Ibid, p 2 referred, inter alia, to the Lord Chancellor and to every justice of the king's bench and the Master of the Rolls.

${ }^{193}$ Ibid. 'the steward of the sheriff's tourn, the steward of a leet...every of these are conservators of the peace, within their several courts; for every of them may commit him to ward that shall make an affray in their presence, whilst they be in execution of their offices, for that these be courts of record: and so in all other courts of record.' For the nature of courts of record see Reeves, n 176, vol 1, pp $95 \& 151$.

${ }^{194} \mathrm{Ibid}, \mathrm{p}$ 3. 'Every of these conservators of the peace (by the ancient common law) are to employ their own valour, and may also command the meet help, aid, and force of others, to arrest and pacify all such, who in their presence, and within their jurisdiction and limits, by word or deed, shall go about to break the peace.'

${ }^{195}$ Coke, n 175.

${ }^{196}$ Ibid, vol 4, p 169 'Sir Anthony Fitz-Herbert, one of the justices of the court of common pleas, [in his text on Justices of the Peace, see text to $n$ 177] and divers others have written of the jurisdiction and power of justices of the peace, both in the court of the sessions of peace, as without; to whose labours I refer the reader.'

${ }^{197}$ Coke did cite the Act of 1488 (see n 174).

${ }^{198}$ Hale, Pleas of the Crown (London, 1685). M Hale, The History of the Pleas of the Crown (printed for E \& R Nutt \& R Gosling, 1736), (written in the 1640-50's but first published in 1678) did not discuss BOTP as such, although it did discuss the commission of JP's, see vol 2, ch 7.

199 Ibid, p 134.

200 Ibid.

${ }^{201}$ DM Walker, The Oxford Companion to Law (Clarendon Press, 1980) (extract on Hale) 'Pleas of the Crown, or a Methodical Summary of the Principle Matters relating to that Subject, merely a series of head-notes and possibly intended as a plan for his History of the Pleas of the Crown. It dates from about 1650 and was printed in 1678 and several times thereafter.'

${ }^{202}$ W Hawkins, A Treatise on Pleas of the Crown (E \& R Nutt \& R Gosling, Savoy ( $1^{\text {st }}$ ed 1716-21, last ed ( ${ }^{\text {th }}$ ed), 1824).

${ }^{203}$ Ibid, vol 1, p 126.

${ }^{204}$ Ibid, pp 133, 155.

${ }^{205}$ Ibid, p 167 'Offences under the degree of capital, more immediately against the subject, not amounting to an actual disturbance of the peace, are either 1. Such as are committed by officers; or 2. Such as are committed by common persons without any relation to an office. Offences committed by officers seem reducible to the following heads. 1 Neglect, or breach of duty 2 Bribery 3 Extortion.' In the final edition in 1824 , Hawkins placed these under the title 'Of Offences against the Public Justice of the Kingdom' (also, perjury and subornation of perjury).
} 
private persons where the offences were also 'infamous and scandalous, ${ }^{206}$ (c) private persons where the offences were not within (b) ${ }^{207}$ (d) private persons where the offences were not within (b) or (c). ${ }^{208}$

This categorisation of Hawkins was personal to him (like many of his categorisations). ${ }^{209}$ However, it was not felicitous and it was discarded by the final edition (instead, Blackstone's methodology was followed). ${ }^{210}$ Further, Hawkins' limiting BOTP to only a few offences of violence is not accurate ${ }^{211}$ since, as Reeves pointed out, by the time of Henry VII (1485-1509), the (king's) peace covered all criminal law. ${ }^{212}$

\section{(b) Burn}

Burn, in the first edition of The Justice of the Peace and Parish Officer (1755) ${ }^{213}$ - a text that was to last until 1869 (see 24) - mainly cited Dalton (see 11) and Hawkins (see 12) for his chapter on 'Justices of the Peace.'214

\section{(c) Blackstone - King's Peace}

Blackstone, in his Commentaries on the Laws of England (1765-9), ${ }^{215}$ discussed the 'king's peace' (which he also called the 'public peace') stating:

The common law hath ever had a special care and regard for the conservation of the peace; for peace is the very end and foundation of civil society...The king's majesty is, by his office and dignity royal, the principal conservator of the peace within all his dominions; and may give authority to any other to see the peace kept, and to punish such as break it: hence it is usually called the king's peace. ${ }^{216}$

Also,

All [criminal] offences are either against the king's peace, or his crown and dignity; and are so laid in

\footnotetext{
${ }^{206}$ Ibid, p 171 'Offences under the degree of capital, more immediately against the subject, not amounting to an actual disturbance of the peace, which may be committed by private persons, without any relation to an office; are either, 1. Such as are infamous and grossly scandalous, proceeding from principles of downright dishonesty, malice, or faction 2. Such as are of an inferior nature, and neither infamous, nor grossly scandalous. Those of the first kind seem to be reducible to the following heads, 1. Perjury, and Subornation of Perjury. 2. Forgery. 3. Cheats. 4 Conspiracy. 5. Keeping of a bawdy house. 6. Libels.' In the final edition in 1824, Hawkins placed nuisances and keeping a bawdy house ( a type of common nuisance) under the title 'Offences against the Public Economy'. See Hawkins, n 202, vol 1, p 685 et seq.

${ }^{207}$ Ibid, p 197. 'Offences under the degree of capital, more immediately against the subject, not amounting to an actual disturbance of the peace, which may be committed by private persons without any relation to an office, and which are of an inferior nature to the six kinds of offences last treated of, being neither infamous nor grossly scandalous, seem to be reducible to the following heads: 1 . Such as more immediately affect the public. 2 Such as more immediately affect the interests of particular persons. Offences of this kind more immediately affecting the public, are four-fold; 1. Common nuisances. 2 Monopolies. 3. Forestalling, Ingrossing, and Regrating. Barratry. In the final edition in 1824, Hawkins placed monopolies,forestalling, ingrossing, regrating and usury under the title of 'Offences against the Public Trade'. Today, monopolies are treated more as a civil, than a criminal issue. Forestalling, ingrossing, regrating and usury are no longer criminal offences.'

${ }^{208}$ Ibid, p 244. 'Offences under the degree of capital more immediately against the subject, not amounting to an actual disturbance of the peace, which may be committed by private persons without any relation to an office, and which are neither infamous nor grossly scandalous, and more immediately affect the interests of particular persons, seem to be reducible to the following heads:.1 Usury. 2. Maintenance. 3. The offence of buying or selling a pretended title.' Usury is no longer a criminal offence, the various forms of maintenance (including champerty and embracery) have been abolished. Buying, and selling, a pretended title appears to have been later treated as an aspect of cheat, which has been abolished. Alternatively, it was a form of maintenance, see e.g. J Gabbett, Treatise on the Criminal Law (Dublin, 1843), p 147.

${ }^{209}$ Hawkins tended to 'lump' together many minor common law offences into larger categories (as in the case, for example, of material on contempt of the sovereign or that of keeping a disorderly house). This was useful for a textbook. However, it was not as the common law (i.e. judges) had so categorized it - a point, often, later forgotten. In the case of his categorization of breaches (and non-breaches) of the peace it was the same.

${ }^{210}$ See 1824 edition, frontispiece.

${ }^{211}$ For example, 'hue and cry' (where citizens were required to uphold the 'peace' and pursue various offenders) covered all felonies, including robbery, theft and not just violent offences. Also, nightwalking which was a misdemeanor. See Coke, n 175, vol 3, pp 116-8.

212 See $n 176$.

${ }^{213}$ R Burn, The Justice of the Peace and Parish Officer ( $1^{\text {st }}$ ed, 1755; last ed, 1869).

${ }^{214}$ Ibid, vol 2, p 66 et seq.

${ }^{215}$ See $\mathrm{n}$ 151. The final edition of Blackstone was effectively that of HJ Stephen, New Commentaries on the Laws of England (4 vols, 1841-5), although much of the input was of the latter.

${ }^{216}$ Blackstone, n 151, vol 1, p 338 'The lord chancellor or keeper, the lord treasurer, the lord high steward of England, the lord mareschal, the lord high constable of England (when any such officers are in being) and all the justices of the court of the king's bench (by virtue of their offices) and the master of the rolls (by prescription) are general conservators of the peace throughout the whole kingdom, and may commit all breakers of it, or bind them in recognizances to keep it: the other judges are only so in their own courts....Constables, tythingmen, and the like, are also conservators of the peace within their own jurisdictions; and may apprehend all breakers of the peace, and commit them till they find sureties for their keeping it.' Blackstone cited Lambard, n 178, pp 12 \& 14. It may be noted that these statements of Blackstone closely follow those of Dalton and were likely based on the latter's work (see 11).
} 
every indictment. For, though in their consequence they generally seem (except in the case of treason and a very few others) to be rather offences against the kingdom than the king; yet, as the public, which is an invisible body, has delegated all its power and rights, with regard to the execution of the laws, to one visible magistrate, all affronts to that power, and breaches of those rights, are immediately offences against him, to whom they are so delegated by the public. He is therefore the proper person to prosecute for all public offences and breaches of the peace, being the person injured in the eyes of the law. ${ }^{217}$

The above statements are useful since they encapsulate the nature of the 'peace' and the 'king's peace' by the $18^{\text {th }}$ century. That is, the Crown was responsible for enforcing the criminal law (conserving the peace) together with officers (such as judges, JP's and constables) appointed by it.

Further, the Crown punished all crimes since this power has been delegated to it by the general public. ${ }^{218}$

\section{(d) Blackstone - JP's}

\section{As to JP's, Blackstone noted:}

The power, office, and duty of a justice of the peace depend on his commission, and on the several statutes, which have created objects of his jurisdiction. His commission, first, empowers him singly to conserve the peace; and thereby gives him all the power of the ancient conservators at the common law, in suppressing riots and affrays, in taking securities for the peace, and in apprehending and committing felons and other inferior criminals. It also empowers any two or more of them to hear and determine all felonies and other offences... ${ }^{219}$

Later, when discussing offences against the public peace, Blackstone stated:

We are next to consider offences against the public peace; the conservation of which is intrusted to the king and his officers, in the manner and for the reasons which were formerly mentioned at large. These offences are either such as are an actual breach of the peace; or constructively so, by tending to make others break it... ${ }^{220}$

After considering felonious breaches of the peace, ${ }^{221}$ Blackstone continued:

Besides actual breaches of the peace, anything that tends to provoke or excite others to break it, is an offence of the same denomination. ${ }^{222}$

In a chapter on preventative justice, ${ }^{223}$ Blackstone noted:

This preventative justice consists in obliging those persons, whom there is probable ground to respect of future misbehaviour, to stipulate with and to give full assurance to the public, that such offence as is apprehended shall not happen; by finding pledges or securities for keeping the peace, or for their good behaviour. ${ }^{224}$

In conclusion, by the time of Blackstone, jurisprudence accorded with reality. By delegation of the people (the public), the Crown enforced the criminal law. Thus, all offences were seen as being against the king's peace or

\footnotetext{
${ }^{217}$ Ibid, pp 258-9. He continues 'And this notion was carried so far in the old Gothic constitution (wherein the king was bound by his coronation oath to conserve the peace) that in the case of any forcible injury offered to the person of a fellow subject, the offender was accused of a kind of perjury, in having violated the king's coronation oath; dicebatur fregisse juramentum regis juratum'. [it was said to break the king's coronation oath]. Blackstone quoted JO Stiernhook, De Jure Sueonum et Gothorum Vetusto (Holmiae, 1672).

${ }^{218}$ It is to be remembered that Blackstone was a staunch protestant. Therefore, post the abdication of James II (1685-8), the 'king's peace' and 'public peace' would be one and the same. That is, it was the people, through Parliament, who permitted the Crown to uphold the criminal law and punish infractions of it.

${ }^{219}$ Blackstone, n 151, p 342.

${ }^{220}$ Ibid, vol 4, p 142.

${ }^{221}$ Blackstone discussed various statutory crimes (now repealed), affray, riots, routs, unlawful assemblies, forcible entry or detainer, riding or going armed, spreading false news, false and pretended prophecies.

${ }^{222}$ Blackstone discussed challenges to fight and (criminal) libels. Blackstone, n 151, vol 4, p 289 also noted that a JP 'may himself apprehend, or cause to be apprehended, by word only, any person committing a felony or [BOTP] in his presence.' Blackstone also stated: 'The constable...may, without warrant, arrest any one for a [BOTP], and carry him before a [JP].' Also 'Any private person (and a fortiori a peace officer) that is present when any felony is committed, is bound by the law to arrest the felon; on pain of fine and imprisonment, if he escapes through the negligence of the standers by'.

${ }^{223}$ Blackstone, n 151, vol 4, p 248 'We are now arrived at the fifth general branch or head...the means of preventing the commission or crimes and misdemeanours....'

${ }^{224}$ Ibid. As to frankpledge, Blackstone noted, p 249, that 'this great and general security being now fallen into disuse and neglected.'
} 
his Crown and dignity. Further, the 'kings peace' and the 'public peace'were one and the same. ${ }^{225}$

\section{Summary of Breach of the Peace up to 1769}

The development of the law in relation to 'peace' - and BOTP - by the time of Blackstone (1765-9) may be summarised relatively succinctly:

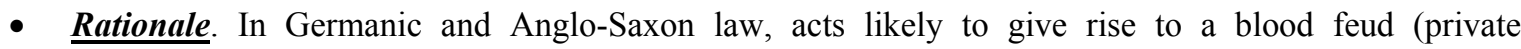
vengeance) were suppressed - in order to enable 'peace' (the absence of public strife) to be maintained. This rationale did not change, although it was little referred to by later legal writers; ${ }^{226}$

- Party Responsible. In Germanic and Anglo-Saxon times, the power to enforce the peace became more concentrated in the king - as opposed to kin and the local community seeking redress. The king secured both a financial benefit (the levying of a wite) and greater power as a result of acting as 'arbiter'. This led to an inevitable tendency to monopolise the judicial function;

- Geographical Reach. By the time of Henry I (1100-35), if not before, the king was asserting that his 'peace' (judicial jurisdiction or protection) applied over all his realm;

- $\quad$ Other Peaces. Besides the 'king's peace' (protection) which was, itself, split into various types, there was God's peace and an individual's peace. Further, there were local courts which had their own 'peace. ${ }^{227}$ However, by 1535 (see 10), all writs and indictments in the palatinates were said to be against the 'king's peace'. Further, local courts such as courts leet and sheriff's county court (both now virtually moribund) were treated as acting by way of Crown franchise. ${ }^{228}$ By Blackstone's time, there was no other 'peace' (criminal law) that applied throughout the realm besides that administered in a Crown (or Crown franchised) court; ${ }^{229}$

- $\quad$ Frankpledge \& Hue and Cry. These Germanic and Anglo-Saxon institutions obligated all men over the age of 12, to conserve the 'peace' (frankpledge) as well as to pursue those who broke it (hue and cry). ${ }^{230}$ By the time of Blackstone, frankpledge and the hue and cry had become moribund and responsibility for conserving the peace was wholly centred on Crown officers such as JP's and constables.

In conclusion, by the time of Blackstone the criminal law and 'breaches of the peace' were one and the same. Further, the jurisprudential analysis was that the Crown - by way of delegation from the public - was responsible for enforcing the criminal law (also called the public peace or king's peace).

\section{Breach of the Peace: 1769-1954}

Apart from subsequent editions of Blackstone, there was very little analysis in any of the texts on criminal law as to the nature of 'peace' and BOTP. Thus, there was no detailed analysis of the meaning of 'peace' or BOTP in the following Victorian legal texts: ${ }^{231}$

- $\quad$ East (1803). The first (and only) edition of his Pleas of the Crown was in $1803 ;^{232}$

- $\quad$ Russell (1819). The first edition of his Crimes and Misdemeanors was in 1819, the last in $1964 .{ }^{233}$

\footnotetext{
225 'Public peace' (as a synonym for the king's peace) can be found in other writers on the criminal law. See e.g. T Wood, An Institute of the Laws of England (printed by W Strahan \& M Woodfall, 1772), p 15 ('offences against the public peace').

${ }^{226}$ Even today the basis of the criminal law may be said to be the punishment of acts by the State which would otherwise result in people taking the law into their own hands (private revenge).

${ }^{227}$ Blackstone, n 151, vol 1, p 113 'by the ancient law, in all peculiar jurisdictions, offences were said to be done against his peace in whose court they were tried; in a court leet, contra pacem domini; in the court of a corporation, contra pacem ballivorum; in the sheriff's court or tourn, contra pacem vice-comitis.' As to counties corporate, Blackstone, p 115 'There are also counties corporate; which are certain cities and towns, some with more, some with less territory annexed to them; to which out of special grace and favour the kings of England have granted to be counties of themselves, and not to be comprised in any other county; but to be governed by their own sheriffs and other magistrates; so that no officers of the county at large have any power to intermeddle therein. Such are London, York, Bristol, Norwich, Coventry, and many others.

${ }^{228}$ The clear legal assertion of this was actually from Bracton (c. 1240), see text to $\mathrm{n} 160$.

${ }^{229}$ The courts of corporations (i.e. counties corporate courts) were franchised since counties corporate were franchises, see $\mathrm{n} 227$. The criminal courts of the Isle of Ely were Crown courts (see n 171) as were any courts of the forest (of the forest of Dean etc), the stannary courts, the led mining courts etc (see Appendix B).

${ }^{230}$ For frankpledge and the hue and cry see McBain, n 106.

${ }^{231}$ Where these texts did consider BOTP was in respect of the power of arrest or specific statutory or common law offences. These are not considered since such material has been superceded. The modern position is considered in 22-4.

${ }^{232}$ EH East, $A$ Treatise of the Pleas of the Crown (only ed 1803).
} 
- $\quad$ Archbold (1822). The first edition of his Summary of the Law relative to Pleading and Evidence in Criminal Cases was in 1822 . This text continues until today; ${ }^{234}$

- $\quad$ Gabbett (1843). The first (and only) edition of his Treatise on Criminal Law was in 1843; ${ }^{235}$

- Harris (1877). The first edition of his Principles of the Criminal Law was in 1877, the last in 1973; ${ }^{236}$

- $\quad$ Stephen (1883). The first edition of his Digest of the Criminal Law was in 1877, the last in $1950 .{ }^{237}$ The only edition of his History of the Criminal Law was in $1883 .{ }^{238}$

Thus, it was not until 1902 that Kenny - in the first edition of his Outlines of Criminal Law ${ }^{239}$-provided some commentary. He stated (under the heading, 'Under the King's Peace'):

The king's majesty is, by his office and dignity royal, the principal conservator of the peace within all his dominions. ${ }^{240}$ Yet there was a time when the king's peace was only partial in its operation, and merely supplemented the national peace which it finally supplemented. The national peace, ${ }^{241}$ which apparently had its origin in the sanctity of the homestead, was protected only in the local courts; and these were weak. The king's peace on the other hand was enforced with vigour by royal officers of justice. At first it applied only in certain holy seasons, or to persons to whom it was specially granted by the king, or to places which were under the king's special protection (such as the precincts of his house and the four great roads). These limits, however, soon became indefinitely extended. 'The interests of the king and of the subject conspired to the same end. ${ }^{242}$ The king profited in the way of fees, and the subject was anxious to appeal to the one authority which could not be lightly disobeyed. Accordingly, after the Conquest, the various forms in which the king's special protection had been given disappear, or rather merge in his general protection and authority. ${ }^{243}$

In 1948, Cross and Jones in the first edition of their, An Introduction to Criminal Law ${ }^{244}$ did not consider 'peace' and BOTP in detail. As to why all these texts did not do so, Allen in 1953 stated:

We of this age take it for granted that the peace established by law is that of the whole community and that everybody shares equally in it. 245

That is, that the criminal law applied generally. And - Allen might have added - that all courts that applied the criminal law did so on behalf of the Crown. As to BOTP being the same as reference to 'breach of the criminal law', reference may also be made to Denning LJ in Everett $v$ Ribbands (1952) where he stated in the case of binding over to keep the peace (surety of the peace):

\footnotetext{
${ }^{233}$ WO Russell, A Treatise on Crimes and Misdemeanors ( $1^{\text {st }}$ ed, 1819). The last edition of Russell (the $12^{\text {th }}$ ed) was in 1964 , edited by JWC Turner.

${ }^{234}$ W Archbold, Criminal Pleading, Evidence and Practice (Sweet \& Maxwell, 2015).

${ }^{235}$ Gabbett, $\mathrm{n} 208$.

${ }^{236}$ SF Harris, Principles of the Criminal Law (Stevens \& Haynes, 1877). The last edition (22 ${ }^{\text {nd }}$ ed) was in 1973 (edited by Ian MacLean). The second edition (1881), p 102 stated: 'Many of the crimes mentioned in other chapters involved a [BOTP]. But the offences now to be dealt with are those in which the [BOTP] is the predominant feature.' He then went on to discuss riots, affray, challenge to fight, sending threatening letters, libel and indictable slander and forcible entry or detainer.' See also HW Disney \& H Gundry, The Criminal Law. A Sketch of its Principles and Practice (1895), p 93-6 which discussed, under the title 'Breach of the Peace', riot, affray, challenge to fight, disturbing public worship, forcible entry and surety of the peace.

${ }^{237}$ JF Stephen, A Digest of the Criminal Law (Macmillan \& Co, $1^{\text {st }}$ ed 1877). The last edition was the $9^{\text {th }}(1950)$. The Digest was a consolidation of all criminal law which Stephen hoped might become the basis of legislation (his hope was unfulfilled). It may be noted that Stephen did not specify BOTP as a crime in itself.

238 JF Stephen, A History of the Criminal Law of England (Macmillan \& Co, 1883).

${ }^{239}$ See $\mathrm{n} 120$. See also JWC Turner, Kenny's Outlines of Criminal Law $\left(19^{\text {th }}\right.$ ed, 1966, last edition).

${ }^{240}$ He cited Blackstone (see 12).

${ }^{241}$ This reference is slightly confusing. It should refer to the fact that local courts (such as courts leet) had a 'peace' (criminal jurisdiction) that was not the king's peace.

${ }^{242}$ Kenny cited Pollock, n 78, p 83.

${ }^{243}$ Kenny, n 120, p 130. Kenny cited Pollock, n 78, p 87.

${ }^{244}$ R Cross \& PA Jones, An Introduction to Criminal Law (2 ${ }^{\text {nd }}$ ed, 1949). The $1^{\text {st }}$ ed was in 1948

${ }^{245}$ Allen, n 103, p 10 'The sovereign herself is encompassed by the law of treason, and special safeguards apply to her representatives like her lord chancellor and her judges in the seat of office; but otherwise no man is more entitled to the cloak of the Queen's peace than any other. Not so with the Anglo-Saxons. There was not yet any established, comprehensive peace of the whole realm. While we think of wrongdoing as a breach of the peace, our ancestors thought of it as a breach of a peace. Each man carried with him a personal shield against unwarranted attack or molestation and it varied greatly according to his social rank.'
} 
An order to find sureties...can only be made...if two things exist; first, a threat by words or conduct to break the law of the land or to do something which is likely to result in a breach, secondly, a reasonable fear that this threat will be carried into effect. The order, once made, will result in imprisonment if the accused man has no friends to stand by him. The imprisonment must be founded on something actually done by him. It would be contrary to all principle for a man to be punished, not for what he has already done, but for what he may hereafter do. Hence there must be something actually done by him, such as threats of violence, interference with the course of justice, or other conduct which gives rise to the fear that there will be a breach of the law. (italics supplied)

Here, it is clear that Denning LJ equated BOTP with breach of the criminal law. One would agree.

In conclusion, by 1954 the 'peace', 'king's peace' and 'public peace' were all synonyms for the criminal law. Further, 'breach of peace', 'BOTP', 'breach of the Queen's peace' and to 'break the law of the land' were all synonyms for breaking the criminal law.

\section{Glanville Williams (1954 \& 1961)}

\section{(a) 1954 Article}

Williams, in an article in $1954,{ }^{246}$ considered arrest for BOTP. It is not necessary to discuss his analysis of the caselaw since it has been superceded. However, he stated at the outset of his article:

The expression 'breach of the peace' seems clearer than it is and there is a surprising lack of authoritative definition of what one would suppose to be a fundamental concept in criminal law. ${ }^{247}$

This statement is something of a personal observation since BOTP refers to any crime - as provided by Denning LJ in 1952 and Allen in 1953 (see above). Williams then stated:

Of course, 'breach of the peace' as a technical expression has a narrower meaning than the breach of the Queen's peace which is supposed to underlie every crime (Grant v Moser (1843) 5 M \& G 123 at 130).

This was merely a technical point; substantively BOTP and 'breach of the Queen's peace' are the same. In his case ${ }^{248}$ an information for false imprisonment (a common law offence) was brought by a householder against a person for persistently ringing his doorbell even when asked to stop. ${ }^{249}$ As a technical point of pleading ${ }^{250}$ where a common law misdemeanor (ie. criminal trespass) was committed it had to be pleaded as being 'in breach of the Queen's peace' since - if not - it was a matter for the court leet or the sheriff's county court (being against the lord of the manor or the sheriff's 'peace'). This was understood by Creswell $\mathrm{J}$ in the case, who stated:

Every trespass is laid as a breach of the peace. Suppose the plaintiff had blown a horn in front of the defendant's house that might have been a breach of the metropolitan police act ( $2 \& 3$ Vict, c 47 . See sect $54 \operatorname{div} 14)^{251}$

As it was, the pleading was bad since the information (plea) said 'against the peace of our lady the Queen.' This was dismissed as insufficient by Tindal CJ who stated: 'These are mere verba sonantia' ${ }^{252}$ (sonorous words). This was sheer technicality (much beloved of the Victorians) since, doubtless, if the word 'against' had been 'in breach of', the plea would have been fine. In conclusion, BOTP and 'breach of the Queen's peace' are the same thing.

\footnotetext{
${ }^{246}$ G Williams, Arrest for Breach of the Peace [1954] Crim LR 578.

247 At p 578.

$2485 \mathrm{M} \& \mathrm{G} 123$ (134 ER 507).

${ }^{249}$ The information was mis-conceived in any case since the offence should have been brought under the Metropolitan Police Act 1939 , s 54 (the householder living in the metropolitan police district), since s 54(16) made it a crime to wilfully and wantonly disturb any inhabitant by pulling or ringing any doorbell or knocking at any door without any lawful excuse. In such as case, being a statutory offence, the plea need not have needed to make reference to the Queen's peace (only to the statute). For example, see Clarke v Higgins (1862) 11 CBNS 545 (142 ER 909). This case dealt with persistently ringing a doorbell under the Town Police Clauses Act 1847 (which Act was designed to extend many of the provisions of the Metropolitan Police Act 1839 to specified towns and districts viz. those which had local Acts that referred to the 1847 Act, incorporating its terms by reference. In this case the 1847 Act was incorporated with the Wellington, Salop, Improvement Act 1845). Also, in this case, the information (plea) simply stated: 'contrary to the statute' (see p 545) and no objection was raised.

250 The point was technical since, by 1843 , there were likely few such courts still operating.

$2515 \mathrm{M} \& \mathrm{G} 123$ (134 ER 507) at p 130.

${ }^{252}$ At p130. Also, p 128 'The defendant...ought to have alleged that the plaintiff was committing a [BOTP]'.
} 


\section{(b) General Part (1961): Meaning of BOTP}

In his Criminal Law: The General Part (1961) ${ }^{253}$ Williams re-iterated his statement in his article of 1954 that there was a lack of authoritative definition of what constituted a BOTP. ${ }^{254} \mathrm{He}$ also stated:

It is clear that a person may be bound over to be of good behaviour if he has committed or threatened any criminal offence, whether or not this involves any blemishing of the peace on his part, and whether or not the offence is otherwise within the jurisdiction of magistrates. ${ }^{255}$ (underlining supplied)

This statement seems wholly correct. As examples of BOTP, Williams cited battery (including a prize fight), assault, inciting others to commit a crime ${ }^{256}$ and criminal libel (now abolished). Williams also referred to the case of Beaty v Glenister (1884) ${ }^{257}$ where persons making a noise were acquitted of 'disturbing the public peace' within a local Act. ${ }^{258}$ This would also seem correct since no crime had been committed. Williams then stated:

The term 'peace' in its popular sense sometimes means quietude, but this is not its legal meaning. Nor, in the present context, does it refer to the king's peace that in historical theory underlay the criminal law. Every crime is a breach of the royal peace, but the notion of crimes involving a breach of the peace is a specific one. $^{259}$

The statement 'every crime is a breach of the royal [ie. the king's] peace' is correct. The underlined wording relates to Grant $v$ Moser (see (a) above).

\section{(c) General Part (1961) - Binding Over}

Williams believed that JP's were using their power to bind over for good behaviour pursuant to the Justices of the Peace Act 1361 ('JPA 1361') persons who had not committed (or threatened to commit) a BOTP. However, he cited few instances of this.

- Williams referred to persons being bound over for being a: (a) common scold; (b) nightwalker; (c) evesdropper; (d) under the Unlawful Games Act $1541 .{ }^{260}$ However, this was not on the basis these were not crimes (he accepted they were) ${ }^{261}$ but that they were clearly obsolete and should be abolished (they all now have been). ${ }^{262}$

Besides these instances, ${ }^{263}$ Williams stated:

The first and only decision of a superior court in England countenancing an extended view of the power is the comparatively recent case of Wilson $v$ Skeock $[1949]{ }^{264}$ A Divisional Court there held that a person may be bound over on account of insulting language, which may provoke a person to whom it is directed to break the peace. Insulting language is not in itself a criminal offence; it is an offence in some

\footnotetext{
${ }^{253}$ G Williams, Criminal Law: The General Part (2 ${ }^{\text {nd }}$ ed), pp 714-5. See also G Williams, Preventive Justice and the Rule of Law (1953) Modern LR, vol 16, pp 417-27.

${ }^{254}$ Ibid, p 714.

${ }^{255}$ Ibid, p 715.

${ }^{256}$ Williams cited Lansbury v Riley [1914] 3 KB 229 (inciting others to commit malicious (now criminal) damage).

25751 LT 304.

258 The Salvation Army marched through the streets making a noise, followed by a mob also making a noise. They were acquitted of 'disturbing the public peace' under a local Act. The Salvation Army - and the disturbance which followed them - was a theme of late Victorian times. See also (not cited by Williams) Beatty v Gillbanks (1882) 9 QBD 308 (Salvation army march through the streets of Weston-super-mare. Held no evidence of unlawful assembly).

259 At p 715.

${ }^{260}$ Williams, n 253, pp 717-8. This Act (now repealed) gave a power to bind over those who haunted gaming houses. For the close connection between gaming and bawdy houses see GSMcBain, Abolishing the Common Law Offence of Keeping a Disorderly House (2015), vol 8, no 2, pp 17-53.

${ }^{261}$ He accepted this, p 718 'these are ancient offences'.

${ }^{262}$ As early as 1843 , the Royal Commission considered evesdropping to be obsolete, see $7^{\text {th }}$ Report of HM's Commissioners on Criminal Law (11 March 1843)(reprinted in the Irish University Press series), vol 4, p 13 'There are several antiquated offences, characteristic of the rude simplicity of the times when they were made the subject of prosecution as crimes which we have ventured to omit [in their draft Criminal Law or Digest], and which ought, we think, to be expressly repealed if any common law misdemeanours other than those included in the Digest are retained. These are the offences of eaves-dropping, or listening under other men's walls or windows, or the eaves of a house, to harken after discourse, and thereupon to frame slanderous and mischievous tales...'

${ }^{263}$ Williams also referred to $R v$ Dunn (1840) 12 A \& E 599 (113 ER 939) where it was held that a man could not be bound over to keep the peace for the continual pestering of a woman. This would seem appropriate since it was not a crime then and Williams did not suggest otherwise, p 715. Today, it would be harassment.

${ }^{264} 65$ TLR 418, 113 JP 298.
} 
circumstances under the Public Order Act [1936], but those circumstances were not present in Wilson v Skeock. $^{265}$

This case involved neighbours. One, using abusive and insulting language at the other not in a public place, was bound over to keep the peace. He appealed.

- The appeal was dismissed by Goddard CJ and Oliver and Cassels LJJ. They held that the Public Order Act 1936, s $5^{266}$ only applied vis-a-vis a public - and not a private - place;

- However, Goddard CJ expressed the opinion that it would have been better for the respondent to have brought the case under the JPA 1361 by complaining that - by reason of the insulting words and conduct of the appellant - a BOTP was likely since the judge could then exercise a power of 'preventative justice' under that Act (or their commission) to bind over persons 'who, they apprehend, may commit breaches of the peace though up to the time when they were brought before the justices they had not actually committed a [BOTP] or any criminal offence. ${ }^{267}$ This would seem perfectly correct, since a person can be bound over for a threatened crime. However, Goddard CJ failed to note that insulting language was not an offence in itself;

- One would agree with Williams that the court was wrong on upholding the appeal since no crime had had been committed or threatened. ${ }^{268}$

Williams mentioned other cases of persons bound over for good behaviour pursuant to the JPA 1361 even though no criminal offence had been committed (or threatened):

(a) breaking into a house; ${ }^{269}$

(b) a man entering a ladies lavatory, frightening a woman there (in 1949); ${ }^{270}$

(c) transvestism;

(d) a man loitering in a lane and endeavouring to speak to women (in 1959);

(e) girls haunting military camps during World War One (1914-18) and Two (1939-45);

(f) peeping toms.

Today, (c) is not a crime and (b), (d) and (f) would likely, now, constitute harassment under the Public Order Act 1986 (see ss 4A and 5). As to (e), in olden times such woman (if prostitutes) would likely have been punished pursuant the law martial (military law). ${ }^{271}$ Today, such circumstances would be very unlikely, given modern security around military camps. ${ }^{272}$ Further, in any case, such women could (possibly) be charged with the common law offence of outraging public decency. ${ }^{273}$

\footnotetext{
${ }^{265}$ Williams, n 253, at p 717.

${ }^{266}$ Durham County Justices (a court of summary jurisdiction) had bound over on the basis of the Public Order Act 1936, s 5 which provided that 'Any person who in any public place or at any public meeting uses threatening, abusive or insulting words or behaviour with intent to provoke a [BOTP] or whereby a [BOTP] is likely to be occasioned, shall be guilty of an offence.'

${ }^{267} 65$ TLR 418 at 419.

${ }^{268}$ See also (1949) 113 JP 746. Two men climbed into a football ground without permission on a match day. They were stopped by police and, later, bound over although no insulting language had been used.

${ }^{269}$ At $\mathrm{p} 718$ 'Thus a man was bound over for breaking into a house - which, in the absence of felonious intent or actual damage, and apart from the Statute of Forcible Entry [repealed] was a mere civil trespass.'

$27013 \mathrm{~J} \mathrm{Cr} \mathrm{L} 226$ ( $R v$ Banks). In 1949, he was charged at Clerkenwell magistrates'court with insulting behaviour where a BOTP might have been occasioned pursuant to the Metropolitan Police Act 1839, s 54(13). He entered a ladies lavatory in a private theatre. The theatre, not being a public place, there was no breach under that Act. However, the magistrates were satisfied that his conduct might have caused a disturbance and that he was a 'blemisher of the peace' pursuant to the JPA 1361 . He was ordered to find sureties in the sum of $£ 20$, to be of good behaviour of 12 months, and, in default, to go to prison for 2 months.

${ }^{271}$ In olden times in England, military camps were subject to martial (military law) enforced by the Court of Chivalry (also called the court military or the court of the constable and marshal) which was operating prior to Richard II (1377-99). Since 1688, the military jurisdiction of this court passed to courts martial. However, women camp followers prior to that seem to have been subject to martial law. eg. ordinances of Henry V (1413-22) provided that common women (prostitutes) who came within the king's army (or 3 miles of the same) were to be burnt on the right cheek (for a first offence) and imprisoned for as long as should please the marshal (for a second offence). See GS McBain, Abolishing Obsolete Crown Prerogatives relating to Martial Law, Conscription \& Billeting (2012) Int. Law Research, vol 1, no 1, p 21, n 82.

${ }^{272}$ One would suggest that there would be no need for such an offence during peacetime and that specific legislative provision could be made (if necessary) during wartime.

${ }^{273}$ Cf. $R v$ Sandbach [1935] 2 KB 192 where Humphreys J said that justices can bind over 'for causes of scandal, contra bonos mores, as well as contra pacem.' Williams, n 253, cited this, p 720 .
} 


\section{(d) General Part (1961) - Binding Over - Goddard CJ}

It seems Goddard CJ believed that the JPA 1361 gave justices a power to bind over where no crime was committed or threatened. In $R v$ County of London Quarter Sessions Appeals C-ee (1948) ${ }^{274}$ he stated:

there is a consensus of opinion to be found in the books, extending back for some four hundred years, that this Act [JPA 1361], which was described by both Coke and Blackstone ${ }^{275}$ as an Act for preventative justice, does enable justices at their discretion to bind over a man, not because he has committed an offence, but because they think from his behaviour he may himself commit or cause others to commit offences against the king's peace.

This seems quite correct. However, Goddard CJ went on to state:

It is abundantly clear that for several centuries justices have bound by recognizances persons whose conduct they consider mischievous or suspicious, but could not, by any stretch of imagination, amount to a criminal offence for which they could have been indicted.

Goddard CJ cited no examples of this apart from the following:

In Dalton's Countrey Justice, a work of the highest authority, a catalogue is given, not intended I think, to be exhaustive of a large number of instances which would justify sureties for good behaviour being taken. $\mathrm{He}$ starts with rioters and barrators, and goes on to such cases as night-walkers and eavesdroppers, suspected persons who live idly and yet fare well or are well apparelled, having nothing whereupon to live, ${ }^{276}$ and common gamsters. None of these were ever indictable offences...Though it is said in Russell in Crime that eavesdropping was dealt with in the sheriff's tourn and courts leet as an offence, ${ }^{277}$ so far as I am aware no instance can be found in the books for this offence at common law. ${ }^{278}$ It follows, therefore, that nobody can be convicted of eavesdropping or night-walking, or of many of the other matters which are mentioned by Dalton, although no doubt in modern times the necessity for good government in towns and cities has caused the legislature to pass Acts which make what in earlier days were regarded as no more than bad behaviour, criminal offences. ${ }^{279}$

With respect to Goddard CJ, Russell on Crime is correct.

- Nightwalking and evesdropping were criminal offences. Not felonies, but misdemeanours. They were punishable in courts leet, the sheriff's county court ${ }^{280}$ and the sheriff's tourn;

- The nature of these offences would have been disclosed to Goddard CJ had the early law of London been cited to him. ${ }^{281}$ In particular: (a) the Liber Albus (also called the White Book); ${ }^{282}$ (b) the Letterbooks of

\footnotetext{
${ }^{274}$ [1948] 1 KB 670. A man had been evesdropping at the Public Trustee's office. He was bound over pursuant to the JPA 1361. On appeal, it was held that the proceedings did not constitute a conviction and, therefore, there could not be an appeal. See also Russell, n 233 (last ed 1964), ch 53 .

${ }^{275}$ For Blackstone, see text to note 224 where he clearly also refers to an 'offence' being apprehended (i.e. threatened). See also Coke, n 175 , vol 4, pp 179-80 re the 1361 Act where JP's 'justly suspect that they intend to break the peace' (ie. to commit a crime). Neither Blackstone nor Coke suggested that the 1361 Act enabled JP's to bind over for good behaviour where no crime had been committed or threatened.

${ }^{276}$ See Dalton, n 187, p 172 (surety for good behaviour) 'also against nightwalkers, that be suspected to be pilferers [thieves], or otherwise like to disturb the peace....against such as by night shall evesdrop men's houses... against suspected persons, who live idly and yet fare well, or are well apparelled, having nothing whereon to live (except [i.e. unless] upon examination, they shall give a good account of such their living). Likely, Dalton took this from the Liber Albus (for the nature of this text see n 282), p 246 (Articles of the Peace, c.1281)(of misdoers who lie concealed) 'some of such [who resort to the City] know nothing but how to go up and down about the streets, more by night than by day, and are well attired as to clothing and array, and feed upon delicate meats and costly; and are employed upon no trade or merchandize, nor have lands or tenements by which to live, or any friends who may find them, and are continually removing from one house to another...' See also Sheppard, n 150, p 48 (nightwalker) 'he that sleeps by day, and walks by night.' (spelling modernized).

${ }^{277}$ See Russell, n 233, ch 53 (I cite the final edition of 1964. An earlier edition would have been cited to Goddard CJ).

${ }^{278}$ Cf. Ibid, vol 2, p 1397 where Russell refers to a later case $R v$ Wyres (Derby Evening Telegraph, 20 September, 1956) where Chesterfield magistrates' court held a person who looked through a window to watch a partially dressed woman washing herself in her kitchen guilty of 'listening under walls, or windows, or house-eaves to frame slanderous and mischievous tales.' The defendant was bound over to keep the peace for 12 months and ordered to pay costs.

${ }^{279}$ [1948] 1 KB 670, pp 674-5.

${ }^{280}$ For nightwalking and evesdropping at the court leet, see Sheppard, $\mathrm{n} 150, \mathrm{p} 48$. The sheriff's county court was different from the tourn, see n 149. See also Russell, n 233, vol 2, p 1397 which cites SS, vol 5, p 70.

${ }^{281}$ For a list of texts on London relating to legal matters, see GS McBain, Modernising the common law offence of Cheating the Public Revenue (2015), Journal of Politics and Law, vol 8, no 1, pp 56-7.
} 

the City of London (the 'City'); ${ }^{28}$ Memoranda Rolls of the City; 285
(c) pleas in the Mayor's court; ${ }^{284}$ (d) the Calendar of Plea and

- Nightwalking was punished where a person broke the curfew in London (usually 9.00am (or dusk, if earlier) until $6 \mathrm{pm}$ ) when the gates of the City were closed. Closure of the gates was provided in the Statute of Winchester (Statutum Wynton) 1285. ${ }^{286}$ However, probably, curfews were imposed by the king prior to this date, certainly in London. ${ }^{287}$ In London, breaching the curfew without good reason would have been a contempt of the sovereign since London was held in the 'king's peace' (i.e. legal jurisdiction) from very early times - at least, from the Conquest - and kings (especially Edward I (1272-1307), II (1307-27) and III (1327-77)) imposed articles (also called statutes) governing it, which articles stipulated various misdemeanours. Probably, other cities received the same in due course.

As to nightwalking and evesdropping in particular, the position would appear to be as follows:

- Nightwalkers. The Letterbooks, Mayor's Court rolls and Plea and Memoranda Rolls provide examples of persons being charged as nightwalkers in London (often, they also carried arms). ${ }^{288}$ Thus:

- The Articles of the Peace for the City ${ }^{289}$ - probably issued in 1281 - ${ }^{290}$ punished persons found wandering in the City after the curfew. ${ }^{291}$ Such persons were placed in prison (usually the Tun

${ }^{282}$ In 1419, John Carpenter made a repertory (a book of remembrances) of the then existing laws, observances, rights and franchises of the City, which is generally referred to as the Liber Albus (White Book). This was translated in 1861, see HT Riley, Memorials of London and London Life AD 1276-1419 (Longman, 1868). See also McBain, n 281, p 56.

${ }^{283}$ These comprise a series of folio volumes, published in 11 volumes, being Letterbooks A to I, then K to L, see Calendar of Letter-Books preserved among the Archives of the Corporation of London at the Guildhall (printed by order of the Corporation under the direction of the Library Committee). They span from 1275-1509. See also McBain, n 281, p 56.

${ }^{284}$ See Calendar of Early Mayor's Court Rolls for the period 1298-1307. See also McBain, n 281, p 57.

${ }^{285}$ Abstracts from the same have been published in 6 volumes from 1323-1482. See Calendar of Plea and Memoranda Rolls (preserved among the archives of the Corporation of the City of London at the Guildhall). See also McBain, n 281, p 56.

${ }^{286} 13 \mathrm{Edw} 1 \mathrm{st} 2$, ch 4 (at what times the gates of great towns shall be shut, and when the night watch shall begin and end) 'for the more surety [safety] of the country the king has commanded that in great towns, being walled, the gates shall be closed from the sun setting until sun rising.' Watchmen were also appointed 'And if any stranger do pass by them, he shall be arrested until morning; and if no suspicion be found, he shall go quit; and if they find cause of suspicion they shall deliver him to the sheriff, and the sheriff may receive him without damage, and shall keep him safely, until he be [acquitted] in due manner.' If a stranger did not obey the arrest, hue and cry could be levied to bring him before the sheriff. This chapter was repealed in 1827 ( 7 \& 8 Geo 4 c 27). An Act of 1331 (5 Edw III c 14) referred to the Statute of Winchester 1275 and stated 'And because there have been divers manslaughters, felonies and robberies done in times past by people that be called Roberdesmen, Wastors, and Draw-latches, it is accorded that if any may have evil suspicions of such, be it day or night, they shall be incontinently [immediately] arrested by the constables of the towns, and if they be arrested within franchises, they shall be delivered to the bailiff of the franchise, and if it is guidable, they shall be delivered to the sheriffs and kept in prison till the coming down of the justices assigned to deliver the goal... and the justices shall proceed to the deliverance of such persons according to the law.' This Act was repealed in 1856. See also Russell, n 233, vol, 2, p 1398.

${ }^{287}$ It was said that William I (1066-87) imposed a curfew in 1068 in London, to prevent disorder against his rule. J Stow, The Survey of London (1598, intro by HB Wheatley, Dent, Everyman's Library, 1965), p 91. Also, Blount, n 133(curfew). There were seven gates to the City in medieval times, see Stow, $\mathrm{p} 27$ et seq.

${ }^{288}$ See, for example: (a) RR Sharpe, Calendar of Letter-books of the City of London (1900), Letterbook B, pp 1-2 (an inquest as to nightwalkers, 1281); (b) AH Thomas, Calendar of Plea and Memoranda Rolls 1364-1381 (1929), p 137 (one John Cheddele was indicted in 1371 for being a 'constant nightwalker to the nuisance of his neighbours.'); (c) AH Thomas, Calendar of Select Pleas and Memoranda of the City of London 1381-1412 (1932), pp 1-2 (three men in 1382 were committed to prison because of wandering by night about $11 \mathrm{pm}$ in a suspicious manner and against the ordinance of the Mayor and the Court of Aldermen. They were mainprised for $£ 20$ each); (d) AH Thomas, Calendar of Plea and Memoranda Rolls 1323-1364, pp 109, 124-6, 213 (in 1339, various nightwalkers were committed to Newgate prison; in 1340 presentments were made against nightwalkers, in 1344 pleas were brought before the Mayor and Sheriffs of the City against nightwalkers); (e) AH Thomas, Calendar of early Mayor's Court Rolls 1298-1307 (1924), pp 159-60 (in respect of an indictment brought pursuant to an Inquest de officio taken by the mayor and sheriffs in 1303-4, a jury held that one Garsias de Sanetere was not a nightwalker).

${ }^{289}$ Liber Albus, n 282, p 228 'These are the Articles, of ancient usage, as to the assize of bread, and of ale, and of other victuals, and as to various mysteries, in the City of London, that ought each year, after the Feast of Saint Michael, to be proclaimed throughout the said City.'

${ }^{290}$ See RR Sharpe, Calendar of the Letterbooks of the City of London. Letterbook A (1899), p 213 which refers to a writ of 28 November 1281 of Edward I (1272-1307) to the Mayor and Sheriffs of London enjoining them to punish all mis-doers walking the city by night with swords and bucklers and assaulting those they met. This writ was re-issued in 1298. It was then re-issued by Edward II (1307-27) in 1320 and by Edward III (1327-77) in 1327, 1328 and 1330. See Thomas, n 288 (d), pp xvi-ii. See also RR Sharpe, Calendar of the Letterbooks of the City of London. Letterbook C (1901), pp 15-7.

${ }^{291}$ Liber Albus, n 282, p 240 'It is also forbidden, that any person shall be so daring as to be found going or wandering about the streets of the City after curfew rung out at Saint Martin's Le Grand and Saint Laurence, or at [Barking church], with sword and buckler, or with some other arm [weapon] for doing mischief whereof evil suspicion may arise, or in any other manner; unless it be some great lord or other substantial person of good reputation, or a person of their household, who from them shall have warranty, and who is going from one to another with a light to guide them. And if any one shall be found going about, contrary to the form aforesaid, if he have no occasion to come so late into the City, he 
or Newgate prison) and then brought before the Mayor's court to explain their conduct. ${ }^{292}$ These Articles may have been the same as certain Statutes of the City of London (Statuta Civitatis London), thought to be issued c. 1285, which are in similar form (they were repealed in 1953); ${ }^{293}$

○ Articles of Edward III (1327-77) for the City proclaimed on 12 June $1363{ }^{294}$ make similar provision against nightwalkers, ${ }^{295}$

○ Where a nightwalker was arrested and fled, hue and cry could be raised to seize him (or her); ${ }^{296}$

○ Nightwalkers were also often prostitutes ${ }^{297}$ or those resorting to brothels. ${ }^{298}$ Prostitutes were forbidden to reside in the City pursuant to the Articles referred to above. If found in the City, they were punished by 40 days in prison. ${ }^{299}$ They were also, often, paraded around the City at the back of dung cart (tumbrel) as well as pilloried. ${ }^{300}$

In conclusion, nightwalking was a misdemeanor. ${ }^{301}$ So, too, for a prostitute to reside in the City. Doubtless, many nightwalkers were prostitutes, so they could be punished for either (or both) offences. However, the curfew in London must have ended - at the latest - by 1660, since the City gates were unhinged then. ${ }^{302}$ Thus, after 1660, 'nightwalking', as such (i.e. simply breaching the curfew), was

shall be taken by the keepers of the peace and put into the Tun which for such misdoers is assigned. And on the morrow, he shall be arrested and brought before the Mayor of the City and the Aldermen; and according as they shall find that such persons have offended and are thereunto accustomed, they shall be punished.'

${ }^{292}$ The 'Tun' was the propular name for the City prison on Cornhill. For the Mayor's court (abolished 1971) generally see GS McBain, Liberties and Customs of the City of London - Are there any Left? (2013) Int. Law Research, vol 2, no 1, p 11.

${ }^{293}$ See Statutes of the Realm, vol 1, p 102 'These be the articles which our lord king [Edward III] doth command to be well kept in his City of London, for the keeping and maintenance of his peace...It is enjoined that no be so hardy to be found, going or wandering about the streets of the City....after the curfew tolled...with sword or buckler, or other arms for doing mischief, or whereof evil suspicion might arise; nor in any other manner.' Any so going were to be imprisoned and the next day brought before the Warden or the Mayor and the Aldermen 'and according as they shall find that he hath offended, and as the custom is, he shall be punished.'

${ }^{294}$ Liber Albus, n 282, p 334. 'The king [Edward III ] to the mayor and sheriffs of London, greeting. We send unto you, enclosed in these presents, certain Articles concerning our peace in the said City of London, by us and our Council ordained, the obligations of which we do hold greatly at heart; commanding you, and strictly enjoining that, immediately upon seeing these presents, you do cause all the Articles aforesaid publicly to be proclaimed in the City of London aforesaid, in such places as unto you shall seem expedient, and strictly to be observed; and that, in accordance with the tenor of the Articles aforesaid, you do cause all who shall contravene the same to be punished and chastised. And this, as you do love ourselves, and our honour, and the safety of the city aforesaid, and shall wish to preserve yourselves unharmed, you are in no manner to omit.' [12 June 1363].

${ }^{295}$ Ibid '[Of keeping the Peace] 'For keeping and maintaining the peace of his lordship the king in the City of London and the suburbs thereof, it is ordained by his lordship the king and his Council, with the assent of the mayor, aldermen and commonality of the City of London, in the manner following; that no one be so daring as to go wandering about within the said city, or in the suburbs, after the hour of curfew...unless he be a man known to be of good repute, or his servant, for some good cause, and that with a light;...And if any one shall be found wandering about, contrary to this Ordinance, he is to be forthwith taken and sent unto the prison of Newgate, there to remain until he shall have paid a fine unto the City for such contempt, and have found good surety for his behaviour.'

${ }^{296}$ Statute of Westminster 1275, ch 9 (see n 139). See also Coke, n 175, vol 3, p 117 'First, if a watchman does arrest a night walker, and he disobey and fly, the watchman may make hue and cry'.

297 The reference were to female prostitutes. Male prostitutes would be punished for the crime of buggery - a felony meriting severe punishment.

${ }^{298}$ Walker, $\mathrm{n} 201$ (nightwalker) 'Persons who go about in the night and often disturb the public peace. At common law, they might be taken into custody until the morning but the offence of being a common nightwalker was abolished in 1967. The word is used in some older statutes to denote a prostitute.'

299 Liber Albus, n 282, p 247 (referring to the Articles of the time of Edward I, c 1281, see n 289).

${ }^{300}$ Ibid, p 395 (in the time of Richard II (1377-99). See also p 287 (Articles of the Wardmotes [i.e. courts leet in the City] of the time of Edward II (1307-27)) 'In the first place, that the peace of God and Holy Church, and the peace of his lordship the king, be strictly kept between clerks and laymen, rich and poor, in common...Item that no woman of lewd life, bawd, or common scold, be resident in the ward; but be forthwith removed by the Aldermen and driven out of the ward, or else be brought by the constables and bedel unto the Compter [sheriff's prison], there to remain in the manner provided in the Article as to the Peace....'. The wardmote, p 32 'is so called as being a meeting together by summons of all the inhabitants of a ward, in the presence of its head, the alderman, or else his deputy, for the correction of defaults, the removal of nuisances, and the promotion of the well-being of such ward.'

${ }^{301}$ By 1445, it was being described as a City 'custom'. PE Jones, Calendar of Plea and Memoranda Rolls 1437-1457 (1954) 'Return that by the custom of the City from time immemorial any person suspected of public adultery, rape, contumely, nightwalking, rebellion or disturbance of the peace ought to be and had been taken and detained in prison until he found sufficient security to await whatever the law and custom of the City should demand in case of conviction...' (italics supplied)

${ }^{302}$ It may also be noted that curfew was rung from Saint Martin's Le Grand (n 291) which church was demolished in 1548. Further, the curfew was imposed by: (a) a standing watch (constables patrolling their particular wards); and (b) a marching watch. The latter ended in the 1550's, see Stow, n 287, p 95. Thus, it is likely that the night curfew in London probably ended c.1550. By 1826, at least, nightwalking seems to have become an aspect of the Vagrancy Act 1824,s 4(persons wandering abroad, lodging in barns etc). See J Chitty, A Practical Treatise on the 
probably no longer an offence in London (or other cities and towns when their curfews ended). Further, adultery and fornication were not treated as criminal matters (but matters for the ecclesiastical court) by the early $17^{\text {th }}$ century. ${ }^{303}$ Thus, post 1660 , it is likely that nightwalkers were charged with more specific offences (theft, robbery etc).

- Evesdroppers. The Oxford English dictionary suggests that the term 'evesdropping' is a later medieval word; the first instance it cites being in $1489 .{ }^{304}$ However, 'evesdropping' may have been a vernacular reference to the crime of spreading false news or tales. ${ }^{305}$

- The latter was an offence punishable pursuant to the Statute of Westminster the First 1275 , chapter $34^{306}$ this being an early form of slander. Although this statutory offence was generally taken to be that of slandering great men (scandalum magnum) it may also have applied in the case of slandering lesser persons as well. ${ }^{307}$ Thus, 'evesdropping' may have been a common term for 'spreading false new or tales', something often connected with nightwalkers; ${ }^{308}$

○ The Liber Albus and the Letterbooks of the City contain many instances were persons were punished for spreading false reports in the City as well as for slandering persons (especially the Mayor and Aldermen of the City); ${ }^{309}$

- Evesdropping was said to have been an indictable offence ${ }^{310}$ although it seems to have been more commonly punished as a misdemeanor in the court leet. ${ }^{311}$ By 1843 , Her Majesty's Commissioners on Criminal Law considered the offence obsolete; ${ }^{312}$

- If evesdropping was a vernacular reference to spreading false news, then it might - in later times - have merged into the generic offence of 'cheat' - a romany cant expression for any form of deceit. $^{313}$ Cheat (apart from cheating the revenue) was abolished by the Theft Act 1968, s 2 .

Criminal Law (2 ${ }^{\text {nd }}$ ed, 1826), vol 4 (precedents of practical forms), p 87 (indictment for night-walking) ' $[\mathrm{X}]$ in the night, taken by the watch set by the constable of [ ] wandering abroad, and lodging in barns, out-houses, or in the open air.'

${ }^{303}$ See e.g. Coke, n 175, vol 3 (published in 1641), p 205 'But now these offences belong to the ecclesiastical court'.

${ }^{304}$ Oxford English Dictionary ('OED') (eavesdrop) 'To stand within the eavesdrop of a house, in order to listen to secrets; hence, to listen secretly to private conversation.' It cites 1489 Nottingham Borough Records III, 10 'Juratores...dicunt ...quod [X] est commune evys-dropper et vagator in noctibus [the jury say that $\mathrm{X}$ is a common evesdropper and nightwalker]'

${ }^{305}$ It is understandable how the term came about. By law, houses could not be build closer than two feet to a person's boundary so that rain did not drop from the roof onto another's land. See also Liber Albus, $\mathrm{n} 282, \mathrm{p} 286$ (evesdrops, the water that drops from his house...falling upon the vacant land of his neighbour). Thus, the notion would be that of a person dripping scandal and lies (false tales) wherever they went. See also Gabbett, n 208, pp 319-20.

${ }^{306}$ Statute of Westminster 1275, c 34 (rep 1887) 'it is commanded that from henceforth none be so hardy to tell or publish any false news or tales [fause novele ou controveure] whereby discord or [occasion] of discord or slander may grow between the king and his people.'

${ }^{307}$ See generally, GS McBain , Abolishing the Crime of Sedition: Part 1, ALJ (August 2008) pp 550-1. Also, Fleta (c. 1290), SS, vol 72, p 106 'There are also certain grievous wrongs that entail prison at the king's pleasure, as in the case of fabricators of false rumours [malorum rumorum $]$ whereby the peace $[$ pax $]$ may be destroyed.'

${ }^{308}$ See e.g. Harding, n 73, p 95 citing Putnam, n 178, p 239 'Inquiry for the lord King [in 1474] whether Robert Morefeld...is a common nightwalker through the windowed courtyards to listen to the counsels and secrets of his neighbours beneath their windows...A true bill.'

${ }^{309}$ See Riley, n 282, pp 430, 433, 454, 474, 476, 479, 493, 507, 576, 585, 592, 605, 630-3. Punishment was the pillory. It may be noted that the offence likely had, originally, a Biblical source, see Book of Exodus, ch 23, v 1 'Do not spread false reports.' Book of Leviticus, ch 19, v 16 'Do not go about spreading slander among your people.'

${ }^{310} \mathrm{G} \mathrm{Jacob}$, A New Law Dictionary $\left(7^{\text {th }}\right.$ ed, 1756)(definition of evesdropper). Evesdroppers, are such persons as stand under the eves or walls of windows of a house, by night or by day, to harken after news, and carry it to others, and thereby cause strife and contention in the neighbourhood, Terms de Ley 317. They are called evil members of the commonwealth; and by the Statute of Westm. $1 \mathrm{c} 33$ [should be a reference to c 34, see n 306] they may be punished, either in the court leet by way of presentment and fine; or in the quarter sessions [abolished 1948] by indictment, and binding to good behaviour. Kitch 11..' The latter is a reference to J Kitchin, Jurisdictions or the Lawful Authority of Courts Leet etc (see e.g. $2^{\text {nd }}$ ed, 1653), p 20 (item for the court leet) 'if any eaves-droppers which stand under the walls or windows, by night or day to hear tales and to carry them to others, to make strife and debate among their neighbours.' See also Termes de la Ley (1641 ed) 'Evesdroppers are such as stand under walls or windows...to hear news.' Also, Blount, Glossographia (1674) 'Eaves-dropper (subauscultor). One that harkens at windows, or eaves of houses, to hear the discourse of others.' See also Sheppard in 1654), n 150, p 48 'The evesdropper, he that does harken under windows, and the like, to hear and then tell news to breed debate between neighbours.' (spelling modernized).

${ }^{311}$ Williams, n 253, p 718 stated that evesdroppers were punished in the leet or sheriff's tourn, citing a prosecution in 1391, mis-citing SS, vol 5, p70 (Leet Jurisdiction in Norwich). W Greenwood, The Authority, Jurisdiction and Method of keeping County Courts, Courts Leet and Courts Baron (printed by E \& R Nutt \& R Gosling, 1730), p 298 (charge of the leet). 'You shall enquire of eves-droppers, such as stand under walls or windows, by night or day, to hear news, and to carry it to others, to make strife and debate amongst their neighbours, these are evil members of the commonwealth, and here inquirable.' Also, 'such offenders are punishable according to the discretion of the jury.'

312 See n 262. 
In conclusion, Goddard CJ was wrong in that a person could be prosecuted for the misdemeanor of being a nightwalker or evesdropper. However, these offences were effectively obsolete by 1948 (when Goddard CJ gave judgment) since:

- curfews in London (and one imagines in most other cities and towns) had ended by 1660;

- the Statute of Westminster 1285, chapter 4 (which provided for the closing of the gates to great towns in the night time) was repealed in 1827 ;

- hue and cry was likely obsolete by the time of the introduction of modern policing in 1829;

- the sheriff's tourn was abolished in 1887 ;

- there must have been very few courts leet operating, even by the early $19^{\text {th }}$ century, to enforce any provision on nightwalking or evesdropping;

- night walking seems to have derived from royal writ (or, possibly, proclamations) in the reigns of Edward I-III. These, writs/proclamations (presumably) lapsed through desuetude and lack of renewal;

- evesdropping possibly derived from the Statute of Westminster the First 1275, c 34 which chapter (section) was repealed in 1887.

Thus, in practice, misdemeanours such as nightwalking and evesdropping were spent by the early Victorian age. As a result, convicting people, thereafter, on the basis of them was rather dubious.

\section{(e) Conclusion - Williams \& Goddard CJ}

One would agree with Williams that the JPA 1361 - which does not make any act a crime as such - ${ }^{314}$ entitles JP's to bind over for good behaviour persons who have committed (or threaten to commit) a criminal offence, but not otherwise, and that Goddard CJ was wrong (if he so believed). That said, Williams provided few examples of this. Further, most of these examples would now be covered by the law on harassment.

\section{Russell (1964), Smith \& Hogan (1965), Kenny (1966)}

Neither the last edition of Russell, in 1964 (edited by Turner), ${ }^{315}$ nor Smith and Hogan - in the first edition of their Criminal Law in $1965^{316}$ - considered 'peace', or BOTP, in any detail. Kenny (in the last edition, in 1966, edited by Turner) stated:

Strangely enough what constitutes a 'breach of the peace' has not been authoritatively laid down. But, as it seems to mean a 'breach of the Queen's peace', it should include every crime... ${ }^{317}$

One would agree with Turner that BOTP should include every crime. However, Brownlie, Law of Public Order and National Security (1981) ${ }^{318}$ stated as to BOTP (much of his commentary was with regard to specific instances of it in the context of arrest without warrant etc, which is dealt with in 21):

The concept of a [BOTP] derives from the early days of the common law. Then the courts relied on notions which, though technical in one aspect, corresponded to lay concepts and common sense. The generic terms trespass, transgression and misdemeanour included a variety of indictable [BOTP]. The modern taste is for precise definition and for the principle 'nulla poena sine lege. '... ${ }^{319}$ Rather oddly it

\footnotetext{
${ }^{313}$ Russell (writing in 1964), n 233, vol 2, p 1159 'It is said to be a misdemeanor to fabricate and publish false news, likely to produce any public detriment. It cites Hale, n 198, p 132. See also McBain, n 281.

${ }^{314}$ Goddard CJ in $R v$ County of London Quarter Sessions Appeals C-ee (1948), see n 274, p 673 'In my opinion the Act of Edward 3 [i.e. 1361 Act] does not create any offence at all.' Also, (1948) 64 LQR, p 313 (case note) 'The [1361 Act] does not create such an offence as 'blemishing the peace', but is solely of a precautionary nature.' See also Laporte (see n 339), p 124 per Bingham CJ 'A [BOTP] is not, as such, a criminal offence, but forms an application to bind over.'

${ }^{315}$ See $\mathrm{n} 233$ (1964 ed), pp 660-2 (re arrest without warrant. This is considered in 22

316 JC Smith \& B Hogan, Criminal Law (1st ed, 1965). See p 279 where they noted that 'A [BOTP] includes a riot, an affray, or an assault or battery committed by $\mathrm{P}$ upon $\mathrm{D}$ or another. Members of an unlawful assembly may be arrested where it is reasonably suspected that there will be a [BOTP].'

${ }^{317}$ Kenny, n 120, p 578. Kenny also noted that 'It has been held in Scotland that a person who peered into lighted windows after nightfall had properly been found guilty of a [BOTP].' Kenny cited Raffaelli $v$ Heatly (1949) SLT 284. Also, 'In another Scottish case, Young v Heatley [1959] Crim LR 438 'grossly improper remarks' made by the deputy headmaster of a technical school at private interviews with students aged 16 and 17 were held to be criminal breaches of the peace.' For BOTP under Scots law, see MGA Christie, Breach of the Peace (1990).

${ }^{318}$ Brownlie, Law of Public Order and National Security $\left(1^{\text {st }}\right.$ ed, 1968, $3^{\text {rd }}$ ed 2012). I cite the second edition edited by Supperstone in 1981.

${ }^{319} \mathrm{He}$ continued, $\mathrm{p} 1$ 'A number of nominate offences in modern law have grown out of the broad concepts of wrongdoing and the lack of precision in definition characteristic of the earlier law. Common assault, challenge to fight, affray, riot, rout, unlawful assembly and sedition are examples of such offences.'
} 
may seem, the creation of a [BOTP] is probably not a substantive crime. ${ }^{320}$ Certainly a case for treating it as a generic crime could readily be established. ${ }^{321}$ Indeed, [BOTP] is an offence in the criminal law of Scotland. Problems of definition exist. Yet they are of no greater magnitude than those attending notions employed in byelaws and the Public Order Act 1936. However, at the present time minor [BOTP] are often dealt with by binding over to keep the peace. And reliance is placed on those various nominate offences and more especially on byelaws and on s 5 of the Public Order Act 1936.

Professor Glanville Williams has remarked on the 'surprising lack of authoritative definition of what one would suppose to be a fundamental concept in criminal law.' Whether or not [BOTP] is a substantive offence at common law outside Scotland, it is a concept relied upon in a large number of contexts. These include the definition of offences (under s 5 of the Public Order Act, byelaws and unlawful assembly) the law relating to binding-over and the law of arrest. An attempt will be made to indicate the significant elements in the concept. Yet the definition may vary according to the functional context. Nevertheless, there is at least a presumption that the concept is unitary. Further, there is no clear evidence of functional diversity, as there is, for example, in the case of the concept of possession. However, a source of confusion is the historical development of the concept. This includes its relation to broad notions of wrongdoing. In the thirteenth and fourteenth centuries it was used as a device to justify the exercise of jurisdiction by the royal courts over a variety of causes. In this connection the concept suffered considerable dilution. The allegation in a writ of a [BOTP] was not traversable. A [BOTP] is, at least for the purposes of the law of arrest, the use of threat of criminal force against the body of another, wherever the event occurs. Glanville Williams considers the general meaning of the concept to be an act involving danger to the person. He doubts whether the English courts would include in it a threat of criminal force against the land or chattels of another.

The concept has a related yet somewhat distinct branch dealing with instances of public violence, being acts 'in terrorem populi'. The offence of affray constitutes an autonomous development of this notion. It is also prominent in the early sources of unlawful assembly and riot. Going armed in public is not itself a [BOTP]. However, the circumstances may create a reasonable apprehension of danger on the part of others. The nature of this public apprehension of danger is not easy to define. ${ }^{322}$ On the other hand, the degree of disturbance which might result from disorderly conduct, abusive language, excessive noise and so on, will not necessarily constitute a [BOTP]. It should only do so if there is a reasonable cause for apprehending a threat or use of force. Disorder which is superficial or self-contained contains no real danger to others. In Wooding $v$ Oxley, Bosanquet $\mathrm{J}$ held that disturbance by noise at a meeting, by cries of 'Hear, Hear', and interjections, would not be a [BOTP]. ${ }^{323}$ However, in a number of cases courts have tended to extend the concept to cover any form of disturbance in the presence of a large gathering of people. ${ }^{324}$ In exercising their preventative jurisdiction to bind over the courts may have produced a specialised version of [BOTP]. ${ }^{325}$ (wording divided for ease of reference)

In conclusion, Turner stated that BOTP meant 'breach of the Queen's peace'. ${ }^{326}$ And, that it should include every crime. This reflects the prior history of the offence. Brownlie referred to the Public Order Act, $s$, now repealed and to a more restricted definition of BOTP in the context of arrest and binding over, which is considered in 21.

\footnotetext{
${ }^{320}$ Brownlie referred to the 1954 article by Williams (see 15(a)) and stated: 'However the decision he cites to support a firm statement that [BOTP] is not in itself an offence (Davies $v$ Griffiths [1937] 2 AE 671) does not support this proposition. The information concerned did not disclose a [BOTP] and on the facts alleged in the information the justices only had a power to bind the appellant over to keep the peace and perhaps to find sureties. [BOTP] is not such an offence in Australia, Canada, India or New Zealand.'

${ }^{321}$ Brownlie cited SS, vol 74, p 6 (a 1308 case where a person was obliged to find mainprise for being a 'common obstructor of the peace' (communis impeditor pacis)). Also 'Cf. the generic offences of conspiracy to corrupt public morals and public mischief.' It may be noted that both conspiracy to corrupt public morals and public mischief are regarded as dubious/obsolete crimes today.

${ }^{322}$ Brownlie referred to the Scots case of Ferguson v Carnochan (1899) 2 White 278 at 281 per Lord Justice-Clerk MacDonald where it was said '[BOTP] consists in such acts as will reasonably produce alarm in the minds of the lieges - not necessarily alarm in the sense of personal fear, but such alarm as causes them to believe that what is being done causes or will cause real disturbance to the community and the breaking up of the peace of the neighbourhood.'

323 (1839) 9 C \& P 1 (173 ER 716).

324 Brownlie cited a Scots case, Whitchurch v Millar (1895) 23 R (Ct of Sess) 1.

325 Brownlie, n 318, pp 1-3.

${ }^{326}$ He may have been slightly hesitant given William's view on Grant v Moser (see 15(a)). However, William's was making a technical point re pleading.
} 


\section{Administration of Justice Act 1977 \& Howell (1981)}

The Administration of Justice Act 1977 (the '1977 Act') made an important change in relation to the analysis of the meaning of BOTP.

- By the time of Henry I (1100-35) the king's 'peace' had extended, in geographical terms, throughout the realm (see 5(b)). However, there still existed a separate 'peace' in legal terms, since local courts such as courts leet and the sheriff's county court - administered their 'peace';

- By 1240, Bracton was asserting that such courts were also administering the 'king's peace' since they were franchised by the Crown (see 7(b)); something which prevailed long before Bracton but which had not been emphasised. By 1535, the palatine courts were administering the 'king's peace' in name as well as juridical reality (see 9);

- Under the 1977 Act, s 23 and Schedule 4, a mass of local courts ceased to operate - including courts leet (also called law days and views of frankpledge) and the sheriff's county court. ${ }^{327}$

This was useful since - from 1977 - there are now no criminal courts other than the king's courts. And all these are administering the king's peace (the criminal law). Also, in the case of Howell (1981), ${ }^{328}$ when reviewing the law on BOTP, Watkins LJ stated:

The public expects a policeman not only to apprehend the criminal but to do his best to prevent the commission of crime, to keep the peace in other words. ${ }^{329}$ (italics supplied)

In conclusion, by 1977, courts leet and other courts which once administered their own 'peace' ceased to operate judicially. Further, in Howell (1981), the court treated 'the peace' and upholding the criminal law as one and the same.

\section{Carter \& Harrison (1991), Thornton (2010)}

These texts mainly dealt with BOTP in the context of arrest without warrant etc. which are discussed in $\mathbf{2 1}$.

\section{(a) Carter \& Harrison}

Carter and Harrison, in Offences of Violence (1991) ${ }^{330}$ did not analyse 'peace' or BOTP in any detail, besides stating that:

A 'breach of the peace' is an act done (or threatened to be done) which actually harms a person or his property in his presence, or puts someone in fear of such harm being done. ${ }^{331}$ A [BOTP] is not to be regarded as synonymous with a 'disturbance'. ${ }^{332}$

They also noted that a constable was under a duty to take reasonable steps to end a BOTP taking place (or to prevent a BOTP which he reasonably believed was about to take place). ${ }^{333}$

\section{(b) Thornton}

Thornton et al, in The Law of Public Order and Protest (2010), ${ }^{334}$ stated:

The classic definition of [BOTP] was given by the Court of Appeal by Watkins LJ in $R v$ Howell: ${ }^{335}$

\footnotetext{
${ }^{327}$ Administration of Justice Act 1977, s 23. Other courts such as courts of pie poudre (piepowder) courts, courts of the staple, courts of the clerks of the market and hundred courts (all of which had minor criminal jurisdiction) also ceased to operate as well as certain specific courts (see Sch 4, pt 2) - all of which courts were long obsolete before 1977. As for the courts listed in Sch 4, pt 3, they, also, should be abolished (many do not now exist and none now perform judicial functions, as such).

${ }^{328} R v$ Howell (1981) 73 Cr App R 31.

${ }^{329}$ Ibid, p 36.

${ }^{330}$ P Carter \& R Harrison, Offences of Violence (1991).

${ }^{331}$ Carter \& Harrison cited Howell (see n 328). They also noted that: 'A [BOTP] can take place on private premises, and a constable is entitled to arrest without warrant anyone whom he reasonably believes is or is about to become involved in a [BOTP] on private premises.'

332 Carter \& Harrison, n 330, p 3. They cited Parkin v Norman [1982] 3 WLR 523.

${ }^{333}$ Ibid, pp 1-3. They cited Albert v Lavin [1981] 74 Cr App R 150 (constable sought to prevent a person queue jumping) in which Lord Diplock stated, at p152 'every citizen in whose presence a [BOTP] is being, or reasonably appears to be about to be, committed, has the right to take reasonable steps to make the person who is breaking or threatening to break the peace refrain from doing so; and those reasonable steps in appropriate cases will include detaining him against his will. At common law this is not only the right of every citizen, it is also his duty, although, except in the case of a citizen who is a constable, it is a duty of imperfect obligation.' They also cited Joyce v Hertfordshire Constabulary (1984) $80 \mathrm{Cr}$ App R 298 (constable used force to restrain a football match spectator who was struggling with another officer). See also Charles McLachlan [1985] IRLR 76 (BOTP can take place on private premises). See also p 22 (referring to the Police and Criminal Evidence Act 1984 ('PACE'), s 17(5)).

334 Thornton et al, The Law of Public Order and Protest ( $1^{\text {st }}$ ed, 2010).
} 
'We are emboldened to say that there is a [BOTP] whenever harm is actually done or likely to be done to a person or in his presence to his property or a person is in fear of being so harmed through an assault, an affray, a riot, unlawful assembly or other disturbance.'

This imposes a higher threshold than the hitherto conflicting authority set by the Court of Appeal in $R v$ Chief Constable of Devon and Cornwall, ex parte Central Electricity Generating Board ${ }^{336}$ in which Lord Denning said that

'There is a [BOTP] whenever a person who is lawfully carrying out his work is unlawfully and physically prevented by another from doing it. ${ }^{337}$

The Howell definition has since been approved both by the European Court of Human Rights (in Steel $v$ $U K)^{338}$ and by the House of Lords in $R$ (on the application of Laporte) $v$ Chief Constable of Gloucestershire Constabulary, ${ }^{339}$ Lord Bingham ${ }^{340}$ emphasizing that in Howell

'The court concluded that the essence of the concept was to be found in violence or threatened violence.'

A person also commits a [BOTP] if his actions provoke violence in others, provided violence is the natural consequence of the person's behaviour. ${ }^{341}$ Failing to acknowledge that others cannot, in some circumstances, reasonably be expected to put up with disruptive activities would be to ignore 'the infirmity of human temper. ${ }^{342}$ (quotations indented for ease of reference)

Thornton also noted that, in Laporte (2007), Lord Carswell identified 3 classes of cases into which most - if not all - BOTP fitted:

- a person committing (or about to commit) a BOTP; ${ }^{343}$

- acts likely to provoke others into committing a BOTP, $;^{344}$

- where a counter-demonstration was likely to provoke a BOTP. ${ }^{345}$

When deciding who was responsible for a BOTP, the courts examined the reasonableness of the actions of both sides and the rights (particularly any European Convention rights) they might be exercising. ${ }^{346}$ Thornton noted:

A [BOTP] is not a criminal offence, except in Scotland at common law, but it is a concept which may lead to police action... It is an 'offence', in a different context; under Article 5(1)(c) [of the Human Rights Convention] in cases where the courts have examined the procedural rights of a person who has

\footnotetext{
${ }^{335}$ See n 328.

${ }^{336}$ [1982] QB 458.

${ }^{337}$ Ibid, p 471.

338 (1999) 28 EHRR 603, paras 25-9 \& 55.

339 [2007] 2 AC 105.

${ }^{340}$ Ibid, para 27, with the agreement of Lord Brown at para 113. Thornton also noted Percy $v$ DPP [1995] 1 WLR 1382 (entering a military base, binding over under the Magistrates' Courts Act 1980, s 115) per Collins J at p 1392 'The conduct in question itself does not have to be disorderly or a breach of the criminal law. It is sufficient if its natural consequence would, if persisted in, be to provoke others to violence, and so some actual danger to the peace is established.'

${ }^{341}$ Thornton cited Steel (see n 338), paras $27 \& 55$ approving Collins J in Percy v DPP (see n 340).

${ }^{342}$ Thornton, n 334, p 255. Thornton cited Channel J in Wise v Dunning [1902] 1 KB 167, 179 (a case of binding over).

${ }^{343}$ Ibid, p 256 'In the first class, which one might regard as the most direct...the person... is himself committing or about to commit a [BOTP].' Lord Carswell cited, as an example, Moss v McLachlan (1985) 149 JP 167 (striking miners stopped from travelling to confront working miners at a pit).

${ }^{344}$ Ibid. 'The second category... concerns people whose acts are lawful and peaceful in themselves but are likely to provoke others into committing a [BOTP].' Lord Carswell cited, as examples, Humphries v Connor (1864) 17 ICLR 1 and Wise v Dunning (see n 342)(where the natural consequence of sectarian acts, words and emblems in the sight of opponents would have been to cause a violent response).

${ }^{345} \mathrm{Ibid}$. 'In the third class of case the actions are not necessarily provocative per se, but a counter-demonstration is arranged, of such a nature that the confluence of demonstrations is likely to lead to a [BOTP].' Lord Carswell cited O'Kelly v Harvey (1883) 10 LR Ir 287 \& (1884-5) 14 LR Ir 105. See also Handyside v UK (1979-80) 1 EHRR 737, para 49 and Redmond-Bate v DPP [2000] HRLR 249, paras 20 \& 21 (Christian fundamentalists preaching on cathedral steps).

${ }^{346}$ Ibid. Thornton cited Simon Brown LJ in Nicol and Selvanayagam v DPP (1996) 160 JP 155, 163 where he stated: 'the court would surely not find a [BOTP by a defendant] proved if any violence likely to have been provoked on the part of others would be not merely unlawful but wholly unreasonable - as, of course, it would be if the defendant's conduct was not merely lawful but such as in no material way interfered with the other's rights. A fortiori, if the defendant was merely exercising his own basic rights, whether of assembly, demonstration or free speech.' (animal rights campaigners sought to disrupt a fishing competition by throwing sticks at the competitors' fishing lines. Held unreasonable and had committed a BOTP).
} 
been arrested and detained by the police and then appears in court at risk of being committed to prison. ${ }^{347}$ Powers to deal with a [BOTP], which are expressly preserved by the Public Order Act 1986 (see s 40(4)), are independent of procedures for dealing with criminal offences. PACE, its Codes, and the Bail Act 1976 do not apply. However, the courts do carefully examine the content and scope of the criminal law when interpreting equivalent $[\mathrm{BOTP}]$ powers in order to ensure that police powers and citizens' rights under the two regimes are broadly compatible. They have not, however, yet determined whether the ingredients of an actual (as opposed to an apprehended), [BOTP] must also amount to the commission of an identifiable criminal offence. ${ }^{348}$

In conclusion, Thornton (like previous writers) indicated that BOTP was not a criminal offence, per se.

\section{Summary - Breach of the Peace: 1066 - 2010}

The historical development of the legal concepts of 'peace', and BOTP, post Blackstone (1765-9 ${ }^{349}$ seem to be uncontroversial.

- $\quad \underline{\text { Rationale }}$. In Germanic and Anglo-Saxon law, acts likely to give rise to a blood feud (that is, to private revenge) were suppressed - in order to enable 'peace' (the absence of public strife) to be maintained. By the time of Blackstone, the jurisprudential logic was that the public had delegated to the Crown (the king) the task of enforcing the criminal law (the 'king's peace'). This logic still prevails - although a modernist would probably say that Parliament (whose representatives reflect the will of the general public) has delegated to the Crown (through its representatives, such as judges, JP's constables etc) the enforcement of the criminal law;

- Geographical Reach. By 1977, courts leet and sheriff's county courts - as well as some remain corporation courts - all ceased to operate. Thus, all criminal courts, post 1977, are the 'king's courts', administering the 'king's peace' (i.e. the criminal law), ${ }^{350}$

- Pleas of the Crown. By the time of Blackstone (1765-9) ${ }^{351}$ all crimes were categorised into: (a) treasons (being exacerbated felonies); ${ }^{352}$ (b) felonies; ${ }^{353}$ (c) misdemeanours. Later, misdemeanours - as well as offences - ${ }^{354}$ became offences of summary jurisdiction. ${ }^{355}$ The categorisation of: treasons, felonies and misdemeanours was abolished in $1967^{356}$ - not least, since it had long been wholly

\footnotetext{
${ }^{347}$ Thornton referred to powers of arrest (dealt with at $\mathrm{p} 262$ et seq in his work) and ch 9 (punishment, appeals, and restrictive orders). Also to Laporte (see n 339), Lord Bingham at para 28, Lord Brown at para 111, Lord Mance at para 137. Also to: Steel (see n 338), paras 46-50, Dyson LJ in the Court of Appeal in Williamson v CC of West Midlands [2004] 1 WLR 14 at para 9, $R v$ County of London Quarter Sessions Appeals C-ee, ex p Metropolitan Police Commissioner [1948] 1 KB 670, 673 \& 676 and to Lord Bingham in Customs \& Excise Commissioners v City of London Magistrates' Court [2000] 1 WLR 2020, 2025.

348 Thornton referred to Lord Mance in Laporte (see n 339), para 137.

${ }^{349}$ For a summary as to Germanic and Anglo-Saxon times, see $\mathbf{4}$ and for a summary from thence, up to Blackstone, see 12.

${ }^{350}$ The only court still operating which is outside the usual court system is the Verderer's court of the New Forest. However, this is treated as a magistrates' court. See Appendix B.

${ }^{351}$ Blackstone, n 151, vol 4, p 5 (he, himself, categorized treasons as an aspect of felony and, thus, tended to refer to felonies and misdemeanours only).

${ }^{352}$ Disney, n 236, p 2 'Treasons are sometimes classed by themselves as crimes of an even higher order than felonies, but treasons are all felonies, though, of course, all felonies are not treasons.'

353 J Paterson, Commentaries on the Liberty of the Subject and the Laws of England relating to the Security of the Person (Macmillan \& Co, 1877), vol 1, p 180 'Felony originally meant judgment of life and members...'

${ }^{354}$ Disney, n 236, p 1 'Acts which the law considers to be public wrongs and, therefore, requites with punishment are crimes, and are either felonies, or misdemeanors, or comparatively trivial acts which do not amount to a felony or misdemeanor and which are commonly called offences.' Ibid, p 2 'There are a vast number of acts or omissions which are punishable by summary process before justices of the peace, but which are of a comparatively trivial nature. They are not commonly called 'crimes' but 'offences', and though the word 'offence' does of course in its widest sense include every kind of crime, it was not unusual to restrict it to these lesser acts, which do not amount either to felony or misdemeanor.'

355 Allen (writing in 1953), n 103, p 33 'We have now reached the point at which we can say that the criminal law of the realm is well grounded upon the king's peace, and to pursue the story father is needless for our present purposes...The vast number of contraventions, belong the degree of pleas of Crown, which had been the concern of subordinate tribunals like the sheriff's tourn and the court leet, fell into the category of misdemeanors and were to become in the course of time, by a host of statutes, 'offences of summary jurisdiction'; this was, and is, another facet of the king's peace...'

${ }^{356}$ Criminal Law Act 1967, s 1(1) 'All distinctions between felony and misdemeanor are hereby abolished. (2) Subject to the provisions of this Act, on all matters on which a distinction has previously been made between felony and misdemeanor, including mode of trial, the law and practice in relation to all offences cognizable under the law of England and Wales (including piracy) shall be the law and practice applicable at the commencement of this Act in relation to a misdemeanor.'
} 
confused and anomalous. ${ }^{357}$ Today, there are only crimes (i.e. public wrongs subject to criminal sanction) and - although the word 'offence' is sometimes used to describe more minor crimes - they are still crimes. ${ }^{358}$ Further, the term 'pleas of the crown' is obsolete since it is, now, no more than a synonym for all crimes;

- $\quad$ Other Peaces. Today, there is only the 'Queen's peace' - those of courts leet, the sheriff's county court etc having gone. Further, the 'Queen's peace' is simply a synonym for the criminal law since the expressions 'peace', 'the Queen's peace', 'public peace', and 'the criminal law' are the same;

- $\quad$ Frankpledge \& Hue and Cry. These are now redundant. Indeed, Blackstone indicated that frankpledge was redundant in his time (see 12(d)) and hue and cry is preserved only in the extent to which a British subject is obliged to assist a constable in respect of acts committed (or threatened) in BOTP. ${ }^{359}$

Thus, today, the 'Queen's peace', in general, is a reference to the criminal law and a BOTP to the commission of any crime (though, as discussed in 20, BOTP has been limited in certain contexts, such as arrest etc). ${ }^{360}$ Given this, is asserted that references to BOTP in legislation and in the common law should be modernised, to make them more intelligible to everyone. Prior to considering this, two possible bones of contention which have arisen in the course of the long history of the 'peace' are considered:

\section{(a) Was BOTP ever a crime in itself?}

It is asserted that BOTP was never in English law, per se, a crime, even though it might be one in Scots law. ${ }^{361}$ This may be readily proved:

- $\quad$ Germanic \& Anglo-Saxon law. These laws were very rudimentary. Acts likely to give rise to a blood feud were punished and the tariffs record what they were (homicide, rape, theft, battery etc) since they required the payment of compensation to the victim (bot) - as well as a fee (wite) to the king, for his assistance in punishing them. However, none of these tariffs record a BOTP as such being an act subject to compensation. Instead, BOTP was a generic reference to such acts;

- $\quad$ Legal Writers. English legal writers from Glanvill to Archbold today have never suggested that BOTP was, per se, a crime under English law. ${ }^{362}$ The nearest any legal writer has suggested this is, perhaps, Brownlie. ${ }^{363}$ Further, if BOTP had been a crime in itself, it would have had to have been categorised as a treason, felony or misdemeanour. Yet it has never been so categorised. Finally, no criminal legislation has ever stated that a BOTP, per se, is a crime - nor the punishment applicable thereto.

In short, BOTP never was a crime in itself. ${ }^{364}$ Further, there is no need to make it so. In modern times, there are a vast array of crimes under English law (great and small) and they have a high degree of specificity. A separate crime of BOTP would be amorphous and capable of almost infinite extent. There would seem to be absolutely no

\footnotetext{
${ }^{357}$ EW Cox, Principles of Punishment (1877), p 6 'It is not difficult to conceive of an abstract distinction between felonies and misdemeanours. But the distinctions established by our criminal law are utterly without reason. It would perplex the ablest of our jurists and criminal lawyers to discover even an approach to a principle by which an offence, from its own nature, has been placed in one category or in the other.' As early as 1877 , Cox (one of the last sarjeants-at law), was arguing for the abolition of the 'absurd' distinction between felony and misdemeanor. Ibid, $\mathrm{p}$ 67.

${ }^{358}$ See $\mathrm{n}$ 354. Given this, it would be much better if all criminal legislation used the shorter word 'crime' which is readily understood by everyone (lawyers and laymen).

${ }^{359}$ The last reference to 'hue and cry' appears to have been in the Sheriff's Act 1887. However, with the development of the modern police force in 1829, it must have been very rare after then. It only ever applied to British male subjects over 12 .

${ }^{360}$ As to why 'BOTP' was not changed to refer to a 'breach of the criminal law', it is to be remembered that the latter expression is new and that, until Victorian times, reference was made to the 'pleas of the Crown' (which expression is obsolete today since all criminal pleas are those of the Crown). Milsom, n 135, p 404 noted 'until the nineteenth century information about what we call the criminal law was to be sought in books entitled "pleas of the crown."

361 See $n 317$.

${ }^{362}$ Nor did the: (i) draft Criminal Code (Digest) of 1843, see n 262, vol 4, in particular, pp 63-4 (offences against the public peace), (ii) $5^{\text {th }}$ Report of the Criminal Law Commissioners (1840), vol 3, p 524 (offences against the public peace); (iii) draft Criminal Code of 1878, see Report of the Royal Commission appointed to consider the Law relating to Indictable Offences (C-2345, 1879), vol 6, part VI (unlawful assemblies, riots, breaches of the peace).

${ }^{363}$ See n 320. However, no coherent analysis of the need, or consequence, of this was provided by Brownlie. Further, the analysis of Williams in 1954 (see 15(c)) in respect of acts not crimes (or threatened crimes) which individuals were being bound over under the JPA 1361, indicates that such are now adequately covered by the law on harassment or not at all (e.g. transvestism), the latter on the basis they are not sufficiently reprehensible to merit the sanction of the criminal law.

364 Archbold, $\mathrm{n} 234$, para 29-60 notes that 'A [BOTP] is not an offence for the purposes of the detention provisions in section 34 of the PACE Act 1984.' It cites Williamson (see 347) and Addison v CC of the West Midlands Police [2004] 1 WLR 29.
} 
need for it, either, since Parliament can easily pass legislation to treat as a new crime, conduct it regards sufficiently reprehensible to merit such.

\section{(b) What does BOTP include?}

It is asserted that BOTP refers to any breach of the criminal law. However, legal writers (and caselaw) when analysing BOTP in the context of:

- $\quad$ arrest without warrant;

- binding over;

- the obligation of a citizen to assist a constable, when requested

have suggested that BOTP - in these instances - should be restricted to crimes of public disturbance or violence. This was not so in olden times, when, for example, citizens had an extensive power of arrest. ${ }^{365}$ However, as Watkins LJ pointed out in Howell (1981), these older cases on BOTP are of little assistance in modern times and any limitation, today, should be viewed in the context of the 'public interest'. ${ }^{66}$ One would agree. Thus, the starting point for any analysis of such should be Howell (1981).

In conclusion, given that the 'peace', 'Queen's peace' and 'public peace' mean the same as a reference to the criminal law in modern times, BOTP should be a reference to any breach of the criminal law - something which is readily understandable by laymen as well as lawyers. However - since BOTP is also referred to in specific contexts (such as arrest without warrant) replacing BOTP in these contexts is now considered.

\section{Archbold (2014)}

\section{(a) Arrest without a Warrant}

In respect of a BOTP ${ }^{367}$ Archbold states, as to arrest without a warrant:

There is a common law power of arrest vested in both the police and ordinary citizens where

(a) a $[\mathrm{BOTP}]$ is committed in the presence of the person making the arrest, or

(b) the arrestor reasonably believes a [BOTP] will be committed in the immediate future by the person arrested - although he has not yet committed any [BOTP]; or

(c) where a [BOTP] has been committed and it is reasonably believed a renewal of it is threatened. ${ }^{368}$

Archbold then considers issues relating to:

- the belief of the arrestor; ${ }^{369}$

- reasonable steps to stop a BOTP occurring, ${ }^{370}$

\footnotetext{
${ }^{365}$ e.g. Liber Albus, $n$ 282, p 33, a proclamation of 1363 for the City of London stated, in its terms (Articles): Every man of standing in the said city, Alderman and commoner, who is of good repute, have power, in the absence of the officers, to arrest felons and misdoers, and to bring them unto the houses of the sheriffs, that so due punishment may be inflicted upon such misdoers.' (italics supplied). See also Liber Albus, $\mathrm{n}$ 282, p 273 which cites the oath of those under frankpledge in the City of London in the time of Henry V (1413-22) 'You shall swear, that you shall be good and true unto the king of England and to his heirs, kings, and the king 's peace you shall keep; and unto the officers of the City you shall be obedient, and at all times that shall be needful, you shall be ready to help the officers in arresting misdoers, and those disobedient to the king's peace, as well denizens as strangers.' (italics supplied)

${ }^{366}$ Howell (n 328), pp 36-7 'The older cases are of considerable interest but they are not a sure guide to what the term is understood to mean today, since keeping the peace in this country in the latter half of the twentieth century presents formidable problems which bear upon the evolving process of the development of this branch of the common law.'

${ }^{367}$ Archbold, n 234, para 29-60 notes that 'Section 40(4) of the Public Order Act 1986 provides that nothing therein affects the common law powers in England and Wales to deal with or prevent a [BOTP].'

${ }^{368}$ Archbold, n 234, cites Howell (see n 328).

${ }^{369} \mathrm{viz}$. 'In the instances where the power is exercised in the belief that a [BOTP] is imminent, it must be established that it is not only an honest albeit mistaken belief, but a belief which is founded on reasonable grounds [cites Foulkes $v$ CC of the Merseyside Police [1998] 3 AE 705]. The test of reasonableness is objective in the sense that it is for the court to decide whether, in light of what the constable knew and perceived at the time, it was satisfied that it was reasonable to fear an imminent [BOTP]; and the reasonableness of the belief was, therefore, to be evaluated without the qualification of hindsight [cites Redmond Bate, see $\mathrm{n}$ 345]. Allowance must be made for circumstances in which a constable has to make a spur of the moment, decision in an emergency [cites $G v$ Superintendent of the Police, Stroud (1986) $86 \mathrm{Cr}$ App R 92]. Where, however, only a threat to the peace came from the response of others to a public speech which may have been irritating, contentious, eccentric, heretical and/or provocative (provided that it did not intend to provoke violence), there would be no basis for arresting the speaker; the law extends tolerance to opinion of every kind and expects it in conduct of those who dis-agree, even strongly, with what they hear [cites Redmond-Bate, see n 345].

370 'Every citizen (whether a policeman or not) in whose presence a [BОTP] is being, or reasonably appears to be, committed has the right to take reasonable steps to make the person who is breaking or threatening to break the peace refrain from doing so; and these reasonable steps in
} 
- a BOTP on private premises; ${ }^{371}$

- the power to prevent a further BOTP, $;^{372}$

- when the power arises to prevent a BOTP, $;^{373}$

- evidence of a BOTP. ${ }^{374}$

As to what is a BOTP for the purposes of an arrest without warrant, Archbold states:

In Howell...it was held that there is a [BOTP] whenever harm is actually done or likely to be done to a person or in his presence to his property or a person is in fear of being so harmed through an assault, an affray, a riot, unlawful assembly or other disturbance. Agitated or excited behaviour, not involving any injury or threat of injury, nor any verbal threat, is not capable of amounting to a [BOTP]. ${ }^{375}$

And in Hawkes v DPP (2006) ${ }^{376}$ it was held that whilst language and an abusive and aggressive manner might justify an arrest on the ground of an apprehended [BOTP], there had to be an incident of violence for an arrest to be justified on the ground that an actual [BOTP] had taken place; verbal abuse plus a refusal to get out a police car did not amount to such an incident. ${ }^{377}$ (wording divided for ease of reference)

\section{(b) Entry on Premises}

The PACE Act 1984, s 17 provides that a constable may enter, and search, any premises for the purpose of:

(i) executing a warrant in certain circumstances; ${ }^{378}$ or

(ii) arresting a person for an indictable offence or an offence under certain enactments; or

(iii) re-capturing a person under certain circumstances; or

(iv) saving life (or limb) or preventing serious damage to property.

Section 17 (5) provides that - subject to s 17(6) - all common law rules under which a constable had a power to enter premises without a warrant are abolished. Section 17 (6) provides that this does not affect:

any power of entry to deal with or prevent a $[\text { BOTP }]^{379}$

appropriate cases will include detaining him against his will short of arresting him [cites Albert v Lavin, see $\mathrm{n}$ 333]. It followed, therefore, that an assailant's honestly mistaken belief that the person detaining him was not a police officer was immaterial to the issue of guilt upon a charge of assault on a police officer in the execution of his duty [cites Joyce, see $\mathrm{n} 333$ ].

371 'In Mc Connell v CC of Greater Manchester Police [1990]1 WLR 364, it was held that a [BOTP] could take place on private premises even though the disturbance was confined only to the persons immediately involved; the absence of third parties is legally irrelevant. McConnell was followed in McQuade v CC of Hunberside Police [2002] 1 WLR 1347. Police officers are entitled in the execution of their duty to prevent a [BOTP], to enter and remain on private premises, and this is so even where the person threatening the breach was threatening to commit it otherwise than on those premises; and officers would not have to wait for them to cross his boundary before being entitled to arrest him [cites Addison, see n 364].'

372، In CC of Cleveland Police v McGrogan [2002] 1 FLR 707 it was held that: (i) where a person has been arrested for [BOTP], the power to detain to prevent a further [BOTP] is limited to circumstances where there is a real (rather than fanciful) apprehension based on all the circumstances that if released the arrestee will renew his [BOTP] within a short time; the officer making the decision for continued detention must have an honest belief that further detention is necessary to prevent a [BOTP], and there must be reasonable grounds for such belief; continued detention cannot be justified on the ground that sooner or later the arrestee, if released, if likely to breach the peace; (ii) the police practice of treating a person detained for [BOTP] as if the PACE Act 1984 applied is correct, involving as it does the need for regular review of the question whether continued detention is justified.'

373 'In [Laporte, see $\mathrm{n} 339$ ] it was held that whereas at common law every constable, and also every citizen enjoys the power, and is subject to a duty, to seek, by taking reasonable steps, to prevent, inter alia, any [BOTP] (i.e actual violence) which is about to occur [cites Albert $v$ Lavin, see $n$ 333], no power (or duty) will arise to take preventative action unless and until the constable (or citizen) reasonably apprehends that an actual [BOTP] is imminent (about to happen); and even when a [BOTP] is reasonably judged to be imminent, no more intrusive action should be taken than appears necessary to prevent it; the test was the same whether the intervention was by arrest or by action short of arrest, and there was nothing to support the proposition that action short of arrest may be taken when a [BOTP] was not so imminent as to justify an arrest.'

374 'Where the lawfulness of a police officer's (or presumably, an ordinary citizen's) conduct depends upon the existence of a [BOTP], there need not be express evidence that there was a [BOTP] going on if the circumstances were such that this is self-evident [cites Joyce, see n 333 and Nicol, see n 346].

375 Archbold cites Jarrett $v$ CC of West Midlands Police, The Times 28 Feb 2003.

3761 Archbold News 3, QBD (Newman J).

377 Archbold, n 234 , para 29-60.

${ }^{378}$ viz of executing (i) a warrant of arrest issued in connection with or arising out of criminal proceedings; (ii) a warrant of commitment issued under the Magistrates' Courts Act 1980, s 76.

${ }^{379}$ Archbold, n 234, para 15-108. 


\section{(c) Refusing to Assist a Constable}

Archbold states:

Refusing to aid and assist a constable in the execution of his duty, in order to preserve the peace, is an indictable misdemeanour at common law. In order to support such indictment, it must be proved that the constable saw a [BOTP] committed; that there was a reasonable necessity for calling upon the defendant for his assistance; and when duly called on to do so, the defendant, without any physical impossibility or lawful excuse, refused to do so. ${ }^{380}$

\section{(d) Obligations of a Constable}

Archbold states:

It is part of the obligations and duties of a police constable to take all steps which appear to him necessary for keeping the peace, for preventing crime, or for protecting property from criminal injury. ${ }^{381}$

Archbold then notes that there is no exhaustive definition of the powers and obligations of the police, but they are at least three and further include the duty to detect crime and bring an offender to justice. ${ }^{382}$ Archbold then considers a $[\mathrm{BOTP}]$ in the context of the following:

- Entry on Land. Archbold notes that a constable (as with any other member of the public) has implied leave and licence from a householder to enter land and approach the door of a house for the purpose of making inquiries. If requested to leave by the occupier, the lapse of a reasonable time must be deemed necessary to enable him to leave. ${ }^{383}$ Where a constable is off private premises, it is his duty to enter such premises to prevent a [BOTP] ${ }^{384}$ and there is no obligation on a constable who is a trespasser to nullify his unlawful act by leaving the land before taking steps to prevent a [BOTP] which he reasonably anticipates is about to occur on the land; ${ }^{385}$

- Restraining (or Removing) a Person. In respect of the duty of a constable to prevent [BOTP] which he reasonably apprehends, Archbold cites various cases (see also Appendix D). ${ }^{386}$ A police officer is not acting in the execution of his duty if he:

- attempts to prevent a [BOTP] by trying to restrain a person who is using force to prevent an unlawful search by another officer; ${ }^{387}$

- restrains someone in the mistaken belief that he has been lawfully arrested by another officer.

Archbold also cites $R v C C$ of Devon and Cornwall, ex $p$ Central Electricity Generating Board (1982). 389 which held that there must be either a [BOTP] - or a reasonable cause for suspecting there is a real and imminent risk of one occurring - before the police were bound to assist in the removal of protestors

\footnotetext{
${ }^{380}$ Ibid, para 19-277.

${ }^{381}$ Archbold, n 234, para 19-269.

${ }^{382}$ Archbold refers to Rice v Connolly [1966] 2 QB 414 per Parker CJ. See also Rv Waterfield \& Lynn [1964] 1 QB 164 at 170 and Coffin v Smith (1980) 71 Cr App R 221. Archbold also notes that 'Stemming from the constable's duty to give adequate protection to all persons and their property, is his duty to control traffic on public roads (a constable has the right to disobey a traffic regulation or direct another to do so if acting in the execution of his duty to protect life and property).' Archbold refers to Johnson v Phillips [1975] 3 AE 682.

${ }^{383}$ Archbold n 234, para 270 refers to Robson $v$ Hallett [1967] 2 QB 939.

${ }^{384}$ Archbold refers to Kay v Hibbert [1977] Crim LR 226 and $R v$ Lamb [1990] Crim LR 58.

385 Ibid, para 19-270.

386 Archbold cites Duncan v Jones [1936] 1 KB 218, Thomas v Sawkins [1935] 2 KB 249, McGowan c CC of Kingston-upon-Hull [1968] Crim LR 34, King v Hodges [1974] Crim IR 424 and Moss v McLachlan (see n 343). Archbold then considers acts which might take a constable out of the execution of his duty.

387 Archbold, n 234, para 19-272 cites McBean v Parker [1983] Crim LR 339.

${ }^{388}$ Archbold cites Kerr v DPP [1995] Crim LR 394. Archbold continues, para 19-272 'And where a police officer makes an unlawful arrest, and other officer who goes to assist him will also be acting outside the execution of his duty: and if a third party seeks to intervene to prevent such an unlawful arrest, arrest of that third party by the officer not immediately involved in the unlawful arrest could not be justified on the ground of it being necessary to prevent a [BOTP] where the third party had used no more force than was reasonable and had not directed his conduct against anyone other than the officers effecting the lawful arrest; intervention by such an officer to stop the third party from pursuing an attempt to prevent the unlawful arrest would take the officer outside the scope of his duty.' Archbold cites Cumberbatch v CPS; Ali v DPP (2009) $174 \mathrm{JP}$ 149. Archbold then notes that a police officer is entitled to use force to restrain a person from leaving a police station (para 19-272) and in respect of requiring a vehicle to stop (ibid). Also, in respect of citizens under a duty to assist a police officer (ibid).

389 [1982] QB 458.
} 
from a site the Board had the right to eject them from. ${ }^{390}$

If references to a BOTP in these instances (a)-(d) above, were removed - as being less intelligible than a reference to the criminal law - what should they be replaced by?

\section{Replacing References to a BOTP-Constable's Basic Duty}

It is asserted that references to BOTP should be replaced with respect to the matters in $\mathbf{2 0}$, in a way that is absolutely clear and intelligible both to constables and to those assisting them. After all, if a constable - or a citizen - does not know what legal powers they have, the result is likely to be confusion, as well as a failure to act to prevent crimes. These matters will now be considered in this section and sections $\mathbf{2 2 - 4}$. As to the basic duty of a constable, Archbold states it is his duty to:

take all steps which appear to him necessary for keeping the peace, for preventing crime, or for protecting property from criminal injury. (italics supplied)

As to a statutory formulation of this:

- The wording in Archbold in italics is covered by the reference to 'preventing crime'. Thus, it is superfluous;

- Similarly, since 'keeping the peace' is the same as 'preventing crime', it is asserted that legislation should provide that it is the duty of a constable 'to do his best to prevent the commission of crime;'

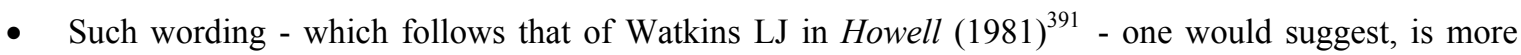
intelligible. Also, it is something that most members of the public (and, indeed, Parliament who represent them) would expect constables to do: to stop crimes being committed. Further, it is not just what might 'appear to him' [i.e. the constable] necessary. It is (one would assert) a duty which should exist regardless of his own view. In short, the job of the police is to uphold the criminal law.

In conclusion, this common law duty should be replaced by a statutory one. One which provides that it is the duty of a constable 'to do his best to prevent the commission of crime.'

\section{Replacing References to a BOTP - Constable: Arrest Without Warrant}

\section{(a) Decision in Howell (1981)}

The reference to BOTP generally is now the same as a reference to the criminal law. However, in Howell (1981), Watkins LJ proposed a definition of BOTP in the context of making an arrest without a warrant:

We are emboldened to say that there is a [BOTP] whenever harm is actually done or likely to be done to a person or in his presence to his property or a person is in fear of being so harmed through an assault, an affray, a riot, unlawful assembly or other disturbance. ${ }^{392}$

A problem with the Howell definition it that it is nebulous in scope (e.g. what does 'other disturbance' mean?) This is not helpful since it is vital that the police (and, even more so, citizens) know exactly when they have the power to arrest - and it should not be for court cases to have to retrospectively determine it. Watkins LJ considered that the 'public interest' dictated that the police should have a fairly extensive power to prevent

\footnotetext{
${ }^{390}$ Archbold, $\mathrm{n} 234$, para 19-274 continues 'But, according toTempleman LJ, they would be entitled to assist at an earlier stage 'In addition to other powers possessed by the police, they are entitled to enter on private land at the invitation of the owner or...of any person who himself has a right to be on the land. The board are entitled to enter on the site and complete the survey and they are entitled to invite the police to enter on the site to assist the board to establish conditions under which the board will be able to complete the survey without the outbreak of violence taking place.' Lawton LJ did not go so far: he said that in the event the protestors did allow themselves to be removed without struggling or causing uproar the police would have no reason for taking action and should not do so.' Also, Archbold notes the right of a constable to use reasonable force when responding to a request under the Licensing Act 2003 (para 19-274).

${ }^{391}$ See Watkins LJ in Howell (1981) 'The public expects a policeman not only to apprehend the criminal but to do his best to prevent the commission of crime, to keep the peace in other words.' (italics supplied). See also 17. Also, Humphries v Connor, n 344, pp 8-9 per Fitzgerald $\mathrm{J}$ 'With respect to a constable, I agree that his primary duty is to preserve the peace; and he may for that purpose interfere, and in the case of an affray, arrest the wrongdoer; or, if a [BOTP] is imminent, may; if necessary, arrest those who are about to commit it, if it cannot otherwise be prevented.' See also Thomas v Sawkins, n 386, at p 254 per Hewart CJ 'the powers and duties of the police are directed, not to the interests of the police, but to the protection and welfare of the public.' Also, $R v$ CC of Devon and Cornwall, $\mathrm{n} 336$, at $\mathrm{p} 471 \mathrm{~A}$ per Lord Denning 'It is to my mind within the authority of the police to intervene to prevent any criminal offence being committed in their presence, where the offender fails or refuses to give, or avoids giving, his name and address. Even though the [law] does not give a power of arrest, the law says that a police officer can do whatever is necessary by way of restraint to prevent a criminal offence being committed or continued.' See also Rice v Connolly, n 382, per Parker CJ at p 419 and Glasbrook Bros Ltd v Glamorgan CC [1925] AC 270, 285 per Viscount Finlay 'There is no doubt that it is the duty of the police to give adequate protection to all persons and their property.'

${ }^{392}$ See n 328, p 37.
} 
BOTP. ${ }^{393}$ One would agree - and this is reflected in the PACE, s 24 which makes statutory provision in respect of a constable's ability to arrest without a warrant.

\section{(b) PACE 1984, s 24}

This section provides that:

(1) A constable may arrest without a warrant - (a) anyone who is about to commit an offence; (b) anyone who is in the act of committing an offence; (c) anyone whom he has reasonable grounds for suspecting to be about to commit an offence; (d) anyone whom he has reasonable grounds for suspecting to be committing an offence;

(2) If a constable has reasonable grounds for suspecting that an offence has been committed, he may arrest without a warrant anyone whom he has reasonable grounds to suspect of being guilty of it.

(3) If an offence has been committed, a constable may arrest without a warrant - (a) anyone who is guilty of the offence; (b) anyone whom he has reasonable grounds for suspecting to be guilty of it.

However, this power is limited. ${ }^{394}$ It is also subject to certain preserved powers of arrest. ${ }^{395}$ In conclusion, pursuant to $\mathrm{s} 24$, a constable may arrest without warrant:

(a) a person who:

- has committed an offence (ss 3); or

- is about to commit one (ss 1); or

- $\quad$ is committing one (ss 1 )

Or,

(b) a person a constable has reasonable grounds for suspecting:

- has committed an offence (ss 3) or

- is about to commit one (ss 1); or

- $\quad$ is committing one (ss 1 )

Or,

(c) a person a constable has reasonable grounds for suspecting:

- has committed a (reasonably) suspected offence (ss 2).

Formulating s 24 in this way makes it more coherent. The question then is whether any common law power is necessary since it is covered by the above.

\section{(c) Comparison of Common Law \& PACE 1984, s 24}

The common law gives a constable the power to arrest without warrant where (underlining supplied):

(a) a [BOTP] is committed in the presence of the person making the arrest, or

(b) the arrestor reasonably believes a [BOTP] will be committed in the immediate future by the person

\footnotetext{
${ }^{393}$ Ibid, p 36 per Watkins LJ 'To deny him [a constable], therefore, the right to arrest a person who he reasonably believes is about to breach the peace would be to disable him from preventing that which might cause serious injury to someone or even to many people or to property. The common law, we believe, whilst recognizing that a wrongful arrest is a serious invasion of a person's liberty, provides the police with this power in the public interest.' See also citations in $\mathrm{n} 391$.

${ }^{394}$ Sub-section (4) provides 'But the power of summary arrest conferred by [ss (1)-(3)] is exercisable only if the constable has reasonable grounds for believing that for any of the reasons mentioned in [ss (5)] it is necessary to arrest the person in question.' Sub-section 5 provides: 'The reasons are (a) to enable the name of the person to be ascertained (in the case where the constable does not know, and cannot readily ascertain, the person's name, or has reasonable grounds for doubting whether a name given by the person as his name is his real name); (b) correspondingly as regard's the person's address; (c) to prevent the person in question (i) causing physical injury to himself or any other person; (ii) suffering physical injury; (iii) causing loss of or damage to property; (iv) committing an offence against public decency (subject to subsection (6)); or (v) causing an unlawful obstruction of the highway; (d) to protect a child or other vulnerable person from the person in question; (e) to allow the prompt and effective investigation of the offence or of the conduct of the person in question; (f) to prevent any prosecution for the offence from being hindered by the disappearance of the person in question.' Sub-section (6) provides '[ss 5(c)(iv] applies only where members of the public going about their normal business cannot reasonably be expected to avoid the person in question.'

${ }^{395}$ See Archbold, n 234, para 15-172. It refers to: (a) Emergency Powers Act 1920, s 2; (b) Prison Act 1952, s 49; (c) Visiting Forces Act 1952, s 13; (d) Children and Young Persons Act 1969, s 32; (e) Immigration Act 1971, s 24(2), sch 2, paras 17, 24 \& 33 and Sch 3, para 7; (f) Bail Act 1976, s 7; (g) Reserve Forces Act 1980, sch 5; (h) Mental Health Act 1983, ss 18, 35(10), 36(8), 136(1) \& 138; (h) Repatriation of Prisoners Act 1984, s 5(5).
} 
arrested - although he has not yet committed any [BOTP]; or

(c) where a [BOTP] has been committed and it is reasonably believed a renewal of it is threatened.

Section 24 is wider than the common law power in that an 'offence' covers any BOTP. Further:

- $\quad$ as to (a), s 24 is wider since a constable can arrest for an offence - even if not committed in his 'presence';

- $\quad$ as to (b), s 24 refers to a person a constable has 'reasonable grounds for suspecting' is 'about to commit' an offence (s 24(1)). The common law refers to one a constable 'reasonably believes will be committed in the immediate future.' It is asserted 'reasonable grounds' and 'reasonably believes' is the same. And that, 'about to commit' is the same as 'will be committed in the immediate future'. Indeed, in both cases, the s 24 wording seems clearer;

- as to (c), s 24(3) refers to where an offence has been committed; the common law to one where a 'renewal' is threatened. It is asserted that s 24 covers the latter since an offence has already been committed. Further, a 'renewal', in any case, falls within s 24(1), because a constable could assert he had reasonable grounds for suspecting an offence was 'about to be committed' - renewal or not. In fact, even with the common law power (c) is not required, since (a) covers (c).

In conclusion, s 24 is wider than the common law power -covering any offence and not just a BOTP. Also, there is manifest duplication with (a) and (b) of the common law power. And, although the common law power of (c) is formulated rather differently (referring to a 'renewal'), it is actually covered by s 24 . Even if not, s 24 should be amended - rather than leave constables (and the courts) to struggle with two separate classifications of the power to arrest without warrant.

In conclusion, the PACE Act 1984, s 24 should contain the only provisions on a constable's arrest without a warrant - in the interests of clarity. Thus, the common law power should be abolished. Further any preserved powers of arrest ${ }^{396}$ should be inserted into $s 24$.

\section{Replacing References to a BOTP - Constable: Power of Entry}

Archbold notes that a constable has authority to:

- enter private property to prevent a BOTP (and being a trespasser does not affect this) (see 20);

- restrain/remove a person to prevent a BOTP.

As with arrest without warrant, both these common law powers refer to a BOTP and it would be anomalous (if not absurd) if a constable's power to arrest was less than that of restraint/removal. The problem, however, in the common law is that these latter two powers have not been dovetailed with that of an arrest without warrant. Nor, indeed, with each other. Thus, confusion reigns.

- Restraint/Removal. It is asserted that the power of restraint/removal should be the same as that of arrest since both are a form of detention - not least for the offence of 'false imprisonment'. ${ }^{397}$ Further, in practice, 'restraint', 'removal' and 'arrest' all have the same common purpose - to prevent people committing - or threatening to commit - crimes. The case of $R v C C$ of Devon and Cornwall, ex $p$ Central Electricity Generating Board (1982) ${ }^{398}$ held that there must be either a BOTP - or a reasonable cause for suspecting there is a real and imminent risk of one occurring - before the police were bound to assist in the removal of protestors from a site the owner had the right to eject them from. If the same scenario occurred today, the police could arrest without warrant under the PACE Act 1984, s 24(3) since the protestors had committed an offence. ${ }^{399}$ Thus, the police could as easily arrest, as restrain/remove them from the site. Indeed, for restraint/removal not to have the same pre-requisites as arrest without warrant is (it is asserted) simply to invite legal nuances and hair-splitting - as well as endless court cases;

- Entering Private Property. The police should have the power to stop crimes, including when they trespass on private property. However, to legally permit the police to enter private property without a

\footnotetext{
${ }^{396}$ See n 395.

${ }^{397}$ See McBain, n 106.

398 See n 336.

399 Town and Country Planning Act 1971, s 281(2).
} 
warrant for every offence (even street offences) would seem unduly wide. It is asserted this, therefore, should be limited only to indictable offences. However, this is covered by the PACE Act 1984, s 17 and it is asserted that the latter is an adequate statement of the law such that an additional right to enter to 'deal with or prevent' a BOTP, by virtue of a common law power, is not required, being already covered (and, if not, $\mathrm{s} 17$ should simply be amended). ${ }^{400}$

In conclusion, it is asserted that common law powers to restrain/remove should be abolished - and the PACE Act 1984, s 24 be amended to refer not just to arrest without warrant but also include the restraint/removal of a person. In the case of entering private premises, the common law power should now be abolished, $s 17$ being amended, if necessary.

\section{Replacing References to a BOTP - Citizen's Arrest \& Assistance}

Two matters need to be considered:

\section{(a) Citizen's Arrest}

It is right, and proper, that citizens should help uphold the criminal law.

- Frankpledge. In medieval times, because there were very few constables (and many were ineffective) British subjects had extensive obligations vis-à-vis the maintenance of the 'king's peace'. Under the system of frankpledge - which existed in Anglo-Saxon times and which continued into medieval times they swore to uphold the peace. And, they were under surety to ensure that the other members of the tithing (or tenmentale or ten families) to which they belonged, did the same; ${ }^{401}$

- Hue \& Cry. Further, under the obligation of 'hue and cry', all citizens were obliged to chase and catch those who broke the 'peace'. This was especially so in the case of murder, theft, burglary, riots, unlawful assemblies, routs and affrays.

By the $19^{\text {th }}$ century frankpledge and hue and cry were obsolete. Thus, the obligation of the citizen vis-à-vis catching criminals was uncertain. So, too, their independent power of arrest.

- In Walters $v$ WH Smith \& Son Ltd (1914), ${ }^{402}$ Reading CJ held - to justify an arrest - a private citizen must show that the particular felony for which he arrested was, in fact, committed (in this case a citizen arrested another on suspicion he had stolen a book, which turned out to be inaccurate).

- It seems that Reading CJ thought that he was deciding this matter for the first time and it was a pity that the early law on the citizen's powers of arrest under hue and cry and - indeed - their obligations (and protections) were not cited to him. ${ }^{403}$

Be that as it may, today, there is a well-established - and well equipped - police force to handle matters in most instances and they usually are on the scene quickly. Further, citizens who 'have a go' may often mis-understand the situation - or injure themselves or others. ${ }^{404}$

\footnotetext{
${ }^{400}$ The PACE Act 1984, s 17 (1)(b) enables entry by a constable for the purpose of 'arresting a person for an indictable offence'. Thus, entry to arrest a person for having committed such an offence overlaps with that of the common law power to arrest where a person has committed a BOTP and the Act should now supercede the common law power which should be abolished. If necessary, however, s 17(1)(b) should be amended to also provide 'or to prevent an indictable offence being committed.' which is presently provided in the common law power to 'prevent' a BOTP (see s 17(6)).

${ }^{401}$ Blount, n 133 (freiburgh) 'Every man in [the] kingdom was associated in a decennary, that is, in a company of ten families, who were pledged or bound to each other to keep the peace and observe the laws, and if any offence was done by one, the other nine were to answer it; that is, if the criminal fled from justice, they had thirty days allowed to apprehend him; if he was not taken in that time, then he who was the friburgh (that is the principal pledge) of the ten should take [in all 12 men] to purge themselves and their friburgh of the forfeiture and flight of the criminal...' (tenmentale) 'These ten men were bound for each other to preserve the public peace, and if either of them was guilty of a breach of the peace, the other nine were to make satisfaction, or to bring the criminal to justice.' (italics supplied)

${ }^{402}$ [1914] 1 KB 595. Also, (1914) 30 LQR, p 146. See also $R$ v Self (1992) 95 Cr App R 42 (citizen's arrest under the PACE Act 1984, s 24. In this case the person whom citizen's sought to arrest had committed no offence. Therefore, he committed no assault on those who sought to arrest him).

${ }^{403}$ Citizens who arrested an innocent man by hue and cry were protected since it was regarded as a fresh suit. To obtain redress the man had to discover the author of the false report. See McBain, n 106, fn 92; Coke, n 175, vol 3, pp 117-8 and Hale (History), n 198, vol 2, p77.

${ }^{404}$ See $R v C C$ of Devon and Cornwall, n 336, p 473 per Lawton LJ 'There are many reasons why self-help should be discouraged.' These included (in his own judicial experience)' as soon as one person starts to, or makes to, lay hands on another, there is likely to be a [BOTP].'
} 
- As it is, the PACE 1984, s 24A makes provision for any person arresting without warrant. ${ }^{405}$ However, this power is limited; ${ }^{406}$

- Given this statutory power - which covers any 'indictable offence' - it is asserted there is no need for a wider power at common law;

- As it is, it would seem that, in general, the public only 'have a go' in respect of offences such as theft, burglary, criminal damage and offences of violence (where another person is being attacked). These are adequately referred to in s $24 \mathrm{~A}(4)$.

\section{(b) Refusing to Assist a Constable}

Archbold notes that refusing to assist a constable in the execution of his duty to preserve the peace, is an indictable misdemeanour. A previous article has considered this crime and it has asserted that - in modern times this crime should be restricted to a refusal to assist with respect to certain crimes only. ${ }^{407}$ Also, it should only apply to males aged between 16-60 who are physically capable of assisting and who do not otherwise have a lawful excuse.

In conclusion, a citizen's common law power to arrest without warrant should be abolished since PACE, s $24 A$ is sufficient. Also, the obligations of frankpledge and hue and cry, should be abolished. Further, the crime of refusing to assist a constable should be limited to certain (listed) crimes.

\section{Replacing References to a BOTP}

In conclusion, it is asserted that references to BOTP should be excised from the criminal laws since they are confusing. And, that the legal concepts of: (a) frankpledge and (b) hue and cry, should be abolished, being obsolete. Instead, the law in this area should be simplified and made more intelligible. Thus,

- a constable should have a duty (enshrined in legislation) to 'to do his best to prevent the commission of crime';

- $\quad$ the common law power of a constable to arrest without warrant should be abolished - the matter being adequately covered by the PACE Act 1984, s 24 (or, if needs be, the latter amended to incorporate any additional common law power);

- the common law power of a citizen to arrest without warrant should be abolished - the matter being adequately covered by the PACE Act 1984, s 24A;

- the common law powers of a constable to restrain and remove should be the same as under the PACE Act 1984, s 24 - with the latter amended to include it;

- $\quad$ the power of a constable to enter private property should be abolished - the matter being adequately covered by the PACE Act 1984, s 174 (or, if needs be, the later amended to incorporate any additional common law power).

\section{Justice of the Peace Act 1361}

\section{(a) Wording of Act}

As well as the instances considered in $\mathbf{2 1 - 4}$, the concept of BOTP is dealt with in the JPA 1361(still extant). It provides:

First, that in every county of England shall be assigned for the keeping of the peace, one lord, and with him three or four of the most worthy of the county, with some learned in law, ...

and they shall have power to restrain the offenders, rioters, and all other barrators and to pursue, arrest, take, and chastise them according to their trespass or offence; and to cause them to be imprisoned and

\footnotetext{
${ }^{405}$ Section 24A(1) 'A person other than a constable may arrest without a warrant - (a) anyone who is in the act of committing an indictable offence; (b) anyone whom he has reasonable grounds for suspecting to be committing an indictable offence. (2) Where an indictable offence has been committed, a person other than a constable may arrest without a warrant - (a) anyone who is guilty of the offence; anyone whom he has reasonable grounds for suspecting to be guilty of it.'

${ }^{406}$ Section $24 \mathrm{~A}(3)$ provides 'But the power of summary arrest conferred by [ss (1) \& (2)] is exercisable only if (a) the person making the arrest has reasonable grounds for believing that for any of the reasons mentioned in [ss (4)] it is necessary to arrest the person in question; and (b) it appears to the person making the arrest that it is not reasonably practicable for a constable to make it instead.' Sub-section (4) provides 'The reasons are to prevent the person in question - (a) causing physical injury to himself or any other person; (b) suffering physical injury; (c) causing loss of or damage to property; or (d) making off before a constable can assume responsibility for him.' Sub-section (5) provides 'This section does not apply in relation to an offence under Part 3 or 3A of the Public Order Act 1986.'

${ }^{407}$ See n 106. See also ns 370 (detention short of arrest) and 372 (detention).
} 
duly punished according to the law and customs of the realm, and according to that which to them shall seem best to do by their discretions and good advertisement, ...

and to take and arrest all those that they may have found by indictment, or by suspicion, and to put them in prison,

and to take all of them that be [not] of good fame, where they shall be found, sufficient surety and mainprise of their good behaviour towards the king and his people, and other duly to punish;

to the intent that the people be not by such rioters or rebels troubled nor endangered, nor the peace blemished, nor merchants nor other[s] passing by the highways of the realm disturbed, nor put in the peril which may happen [alternative translation, put in fear by peril which might happen] of such offenders (wording divided for ease of reference, wording in italics obsolete).

This Act was almost certainly the result of disorders committed in England by English soldiers, returning from France after the treaty of Bretigny, many of whom became rogues and vagabonds. ${ }^{408}$ Further, it does not satisfy modern modes of drafting being repetitious and somewhat rambling. A previous article has argued that this Act should now be repealed ${ }^{409}$ since it is obsolete - given that, today, under more modern legislation:

- JP's are not limited to 'three or four' for each county. Nor are some 'learned in law';

- JP's no longer, themselves, 'restrain', 'pursue' 'arrest' or 'take' offenders by indictment or suspicion (the latter is also obsolete), leaving this to the police;

- The power of JP's to punish ('chastise', 'duly to punish', 'put...in prison') is provided for by the Magistrates' Courts Act 1980, as is their power to require recognizances and sureties (that is, to require the principal or a third party, to post a bond) for BOTP or good behaviour.

However, this Act has not been repealed to date since it is thought that it is the basis for JP's power to bind over for good behaviour (it has never been asserted it is the source of the power to bind over for BOTP since it has been accepted that JP's had this by way of commission prior to this Act).

\section{(b) Binding over for Good Behaviour}

In a previous article, it has been asserted that:

- the proposition that the 1361 Act is the source of the power to bind over for good behaviour (bon porte, good abearing) is inaccurate since it is likely that such a power existed well before this Act (possibly, from 1281 or earlier) ${ }^{410}$ by way of commission. ${ }^{411}$ Thus, this power was not a wholly new device provided for in the Act;

- in any case, the courts ${ }^{412}$ have consistently maintained that - whether or not the power to bind over for good behaviour is - or is not - derived from this Act is irrelevant - since it has been exercised for hundreds of years. Indeed, a commission of 1364 expressly contains such a power. ${ }^{413}$

Further, the Justice of the Peace Act 1968 ('JPA 1968'), s 1(7) provides:

It is hereby declared that any court of record having a criminal jurisdiction has, as ancillary to that jurisdiction the power to bind over to keep the peace and power to bind over to be of good behaviour, a

\footnotetext{
${ }^{408}$ GSMcBain, Modernising English Criminal Law (2010) Coventry LJ, vol 15, issue no 2, p 9. The treaty was signed on 25 May 1360 between Edward III (1327-77) and John II of France (1350-64). It was ratified on 24 October 1360 as the Treaty of Calais. See also J Bellamy, Crime and Public Order in England in the later Middle Ages (1973), p 6 (after the treaty of Bretigny) 'In 1362 there was great clamour about the committing of felonies and trespasses and the excesses of officials. There were reports of large numbers of vagabonds congregating in a warlike manner, as it was put, and living from ambush and pillage in Staffordshire, while felons were thought to be unusually thick on the ground in Devon.' Bellamy cites William Salt Archeological Society, xiv (1893), p 112 and the Calendar of the Patent Rolls, 1361-1364 (Record Commission), vol 12, pp 282, 396.

409 Ibid.

${ }^{410}$ Ibid, p 12, n 85.

${ }^{411}$ For the revision Commission to JP's 1590 (with minor amendment), see Burn ( $1^{\text {st }}$ ed, 1755), n 213, vol 2, p 69 'to cause to come before you, or any one of you, all those who to any one or more of our people concerning their bodies or the firing of their houses have used threats, to find sufficient security for the peace, or their good behaviour, towards us and our people; and if they shall refuse to find such security, then them in our prisons until they shall find such security to cause to be safely kept.'). See also Holdsworth, n 35, vol 1, p 670. For earlier ones, see Putnam, n 178 .

${ }^{412}$ Ibid, p 13. See Lansbury and Riley [1914] 3 KB 229. Also, Sheldon v Bromfield Justices [1964] 573, 577 per Parker CJ 'It is well known that justices have power pursuant to their commission or pursuant to the [JPA 1361], to bind over all persons brought before them.' Also, Ex $p$ Metropolitan Police Commissioner, n 274, p 675 per Goddard CJ.

${ }^{413}$ Ibid, p 12, n 88.
} 
person who or whose case is before the court, by requiring him to enter into his own recognizances or to find sureties or both, and committing him to prison if he does not apply (italics supplied)

It is asserted that this section clearly supplants that in the JPA 1361 since it is irrefutable that JP's have (and exercise) a criminal jurisdiction. But are they a court of record? In times past, JP's performed a wide variety of functions, some civil as well as criminal (fixing carriage and innkeepers' rates for example). ${ }^{414}$ However, it has been held for hundreds of years that, when JP's acted in a criminal capacity they were justices of record including in the case of taking a recognizance or surety for a BOTP or for good behaviour. Thus:

- Court of Record. In 1581, in his work on JP's (Eirenarcha), Lambard noted that JP's were judges of record. ${ }^{415}$ So did Dalton in 1618 (repeated in all subsequent texts until the final edition in 1746). ${ }^{416}$ So did Coke in his Treatise of Bail and Mainprize, ${ }^{417}$ citing a Yearbook case in $1523{ }^{418}$ So did Pulton in 1609. ${ }^{419}$ So did Burn in the first edition of his very popular work in $1755 .{ }^{420}$ Indeed, it seems impossible to find any legal writer who finds otherwise;

- Recognisance or Surety for BOTP and Good Behaviour. Such a recognizance has always been a matter of record, since that is exactly what happened. The amount that would otherwise be forfeit to the

414 JA Sharpe, Crime in early Modern England 1550-1750 (1984), p 28 'Almost from the office's inception, statutes were passed adding to its duties and powers, perhaps 300 of them between the mid fourteenth and late sixteenth centuries. Throughout the period under discussion, the [JP] played a vital role in both law enforcement and county administration in general. The solitary justice was empowered to conduct the preliminary examination of suspects and witnesses in cases of felony, take recognizances, commit suspected felons to prison, and bind over the unruly to be of good behaviour; he was to stop affrays, conserve rivers, and enquire into apprenticeships disputes and differences between master and servant; he could also take steps to suppress vagabonds, rogues, nightwalkers, nocturnal hunters in masks, and players of unlawful games; bind over soldiers who has sold their arms; equipment, or horses to appear at the sessions, or imprison them; he could deal in a similar fashion with those spreading false rumours; seize the goods of gypsies, search wax manufacturers for illicitly made candles, examine and bind over recusants, enquire into poaching cases, and have complaints about suits arising in the county courts referred to him; he could also, in times of dearth, supervise the sale of corn and the production of malt and, in the appropriate counties, control Thames watermen. Two or more justices acting together had yet wider powers. They could look into cases of embracery and maintenance, riots, and poor scholar begging for fees; their local government functions included fixing poor rates and supervising the repair of highways, and appointing overseers of cloth; they were empowered to take action against Jesuits and tax-evaders, take bail, grant alehouse licences, regulate the weights and measures used for tradesmen, and licence pedlars or players; they were also to determine paternity in bastardy cases, order maintenance payments, and assess robbery rates. These statutory powers were wide enough, but the justice also possessed extensive theoretical powers to hear and determine all forms of felony.' For a list in 1911, see GG Alexander, The Administration of Justice in Criminal Matters in England and Wales (1911), p 71. For circumstances where JP's were not acting as judges of record, and their pronouncements were not records, see Lambard, n 178, pp 297-8. ${ }^{415}$ Lambard, n 178, p 3. 'Justices of the Peace be judges of record appointed by the Queen [Elizabeth I, 1558 -1603] to be justices within certain limits, for the conservation of the peace, and for the execution of sundry things comprehended in their commission, and in divers laws committed unto them.' Ibid, p 69 'the justices... are numbered among the judges of record'. Also, p 70 et seq (meaning of record).

${ }^{416}$ Dalton, $\mathrm{n} 187, \mathrm{p} 6$ 'Justices of peace are judges of record, appointed by the king to be justices within certain limits, for the conservation of the peace, and for the execution of divers things comprehended within their commission, and within divers statutes committed to their charge. Now first that the justices of peace are judges of record (yea that every justice of the peace by himself is a judge of record, and one upon whose sole report and testimony, the law reposes itself very much) appears more plainly, if you observe these things following...He may take a recognizance (for the peace etc) which is a matter of record, and which none can do but a judge of record.' Ibid, p 4 'They be called justices (of the peace) because they be judges of record, and withal to put them in mind (by their name) that they are to do justice...' Ibid, p 142 'the justice of peace he being a judge of record.' See also Fitzherbert, $\mathrm{n} 177,(1538 \mathrm{ed})$, fo 7 'he is a justice of record.'

${ }^{417}$ W Hawkins, Three Law Tracts (Professional Books Ltd, 1982), p 290 'the opinion of the whole court in $18 \mathrm{H} 816$ where it is said, that a justice of peace is a judge of record, and therefore ought to proceed upon that thing which is judicially before him of record.'

${ }^{418}$ See 14 Hen 8 pl 3 Vulgate folio 161-16b (1523), Seipp no 1523.003ss (119 SS 142-3) Common Pleas. False Imprisonment. Ibid 'it was likewise agreed by the whole court in that case, that a [JP] cannot make out a warrant to arrest any man of suspicion of felony, before he be therefore indicted; and yet it is there agreed, that he may make a warrant against one before any record thereof; and this does nothing impugn that which has been said, exceptio probat regulam, if the [JP] should stay the arresting of such persons as would break the peace before they were certified thereof by matter of record, the [BOTP] should never have been prevented: for before it be broken, there cannot any record be made thereof etc.' Seipp Index note ' Baker: In False Imprisonment, the defendant pleaded by way of justification that a [JP] had issued a warrant directing him to arrest the plaintiff for felony, which he did. The plaintiff asked how he should reply, his case being that the warrant was issued after the arrest and therefore void. Fitzherbert J. raised the point that a [JP] may not issue a warrant to arrest someone before he is indicted. The court held that, even if the justice could not issue such a warrant, it was a justification for the officer who executed it, since it was not for the officer to question its validity. Issue was joined, but there is no record of any trial.' David Seipp (a professor at Boston university) has put translations of most of the 22,000 Yearbook cases online in the form of an Index. See www.bu.edu/law/faculty/scholarship/yearbooks). ${ }^{419}$ Pulton, n 185, p 17 '[JP's] before the reign of king Edward the third [1327-77] were called conservators of the peace, and sithence [since then] they have been termed justices of peace, because they be judges of record, or otherwise they be named commissioners of the peace, because they have and derive their authority by the king's commission.' The certificate of the release of a recognizance was also a matter of record. Ibid, p 21 ('that certificate being of record.').

${ }^{420}$ Burn, n 213, vol 2, p 66 'Justices of the peace are judges of record, appointed by the king to be justices within certain limits, for the conservation of the peace, and for the execution of divers things comprehended within their commission, and within divers statutes committed to their charge.' 
Crown for breach was recorded. ${ }^{421}$ Lambard, in 1581, noted this ${ }^{422}$ referring to a case in $1405{ }^{423}$ So did, inter alia, Pulton in $1609^{424}$ and Blackstone in $1769 .^{425}$

In conclusion, there would seem to be no doubt that JP's comprise a court of record when exercising their criminal jurisdiction to bind over, whether for BOTP or good behaviour. Thus, the JPA 1968, s 1(7) supplants the 1361 Act in this respect. In conclusion, the latter Act should be repealed.

\section{(c) Consequences of Repealing 1361 Act}

It is asserted that, if the 1361 Act was repealed, it would have no effect since all its content is obsolete anyway being covered by more recent legislation including the JPA 1968, s 1(7) in respect of binding over. However, repealing the 1361 Act would also remove a long standing 'canard' with reference to the ability of JP's:

to take all of them that be [not] of good fame, where they shall be found, sufficient surety and mainprise.

In Anglo-Saxon times, the 'fame' (reputation) of a person was important since it affected their legal status.

- Anglo-Saxon society was one where a person could be outside the law (an 'outlaw'). Thus, they could be killed with impunity. Further, notorious persons - such as 'notorious prostitutes' - could be driven from the land or killed; 426

- All men of 'ill repute and those who have been frequently accused' were required to be placed under surety. ${ }^{427}$ In hundred (wapentake) courts, the twelve leading thegns and reeve 'shall arrest those men of

\footnotetext{
${ }^{421}$ See generally SE Thorne, Essays in English Legal History (Hambledon Press, 1985), chapter on 'Notes on Courts of Record in England', pp 61-73 Also, p 243 et seq. See also Groenvelt v Burwell (1697) 1 Ld Raym 454 at p 467 per Lord Holt (a court of record can fine and imprison).

${ }^{422}$ Lambard, n 178, pp 72-3 every JP by himself 'is a judge of record...And he may take a recognizance for the peace, as appears 7 Hen 434 and common experience tells it, which none can do but a judge of record, because the acknowledging of the sum is to remain as a matter of record.' Ibid, p 83 'surety of the peace. An acknowledging of a bond to the prince [the sovereign] taken by a judge of record, for the keeping of the peace. And it is called surety of the word securitas, because the party that was in fear, is thereby the more quiet and secure.' Release of a surety of the peace is also a matter of record. Ibid, p 118. See also p 206 'The justice of the peace takes usually a recognizance, and is well warranted so to do, being made a judge of record...'

${ }^{423} 7$ Hen 4 pl 22 fo 34a (1405), Seipp, n 404, no 1405.098.

${ }^{424}$ Pulton, n 185, p 21 (the certificate of the release of a recognizance was a matter of record, 'that certificate being of record.'). Ibid, p 13 'In an action of false imprisonment, the defendant justified, for that a [JP] directed a warrant unto him to arrest the plaintiff for felony, which he did And it was holden that a [JP] cannot make a warrant to arrest a felon, unless he be indicted, for he is a judge of record, and he must have a record whereupon he doth award his process.' Ibid, p 18 'And if the party [subject to a recognizance not to breach the peace] make default, the same then there to be recorded: and the same recognizance with the record of that default shall be sent and certified into the chancery, kings bench, or into the exchequer.' See also Blount (in 1717), n 133 (recognizance) 'is a bond or obligation, testifying the recognizor to owe the recognize a sum of money, and is acknowledged in some court of record, or before some judge, master of chancery, justice of peace etc. Also, (surety of peace) '(Securitas pacis, so called, because the party that was in fear was thereby secured) is an acknowledging a bond to the prince, taken by a judge of competent record, for the keeping of the peace. This peace a [JP] may command, either as a minister, when he is willed to do so by a higher authority, or as a judge, when he does it of his own power, derived from his commission.'

${ }^{425}$ Blackstone, $\mathrm{n}$ 151, vol 4 pp 249-50 'This security consists in being bound, with one or more sureties, in a recognizance or obligation to the king, entered on the record, and taken in some court or by some judicial officer; whereby the parties acknowledge themselves to be indebted to the Crown in the sum required; (for instance £100) with condition to be void and of none effect, if the party shall appear in court on such a day, and in the mean time shall keep the peace: either generally, towards the king, and all his liege people; or particularly also, with regard to the person who craves the security. Or, if it be for good behaviour, then on condition that he shall demean and behave himself well, (or be of good behaviour) either generally or specially, for the time therein limited, as for one or more years, or for life...Any justices of the peace, by virtue of their commission, or those who are ex officio conservators of the peace...may demand such security according to their own discretion: or it may be granted at the request of any subject, upon due cause shown...'

${ }^{426}$ Attenborough, n 59, p 109 (Laws of Edmund \& Guthrum, see n 65) 'If wizards or sorcerers, perjurers or they who secretly compass death, or vile, polluted notorious [aebere] prostitutes be met with anywhere in the country, they shall be driven from the land and the nation shall be purified; otherwise they shall be utterly destroyed in the land.' Also, p 27 (Laws of Edgar, III, see n 65) ' if anyone who has a bad reputation and is unworthy of public confidence fails to attend the court meetings three times, men shall be chosen from the meeting who shall ride to him, and he may then still find a surety, if he can. And if he cannot do so, they shall seize him as they can, either alive or dead, and they shall take all that he has, and shall pay to the accuser the unaugmented value of his goods; and the lord of the manor shall take half [of what remains], and the hundred half. And if anyone, either kinsman or stranger, refuses to ride [against him], he shall pay the king 120 shillings. And if the proved thief, or he who has discovered in treason against his lord, whatever refuge he seeks, shall never be able to spare his life, unless the king grant that it be spared.' See also, p 55 (anyone regarded with suspicion by the general public).

${ }^{427}$ Robertson, n 59, p 15 (Laws of Edmund, III, see n 65 ) 'And every man shall act as surety for his men and for all those who are under his protection and on his estate. And all men of ill repute [omnes infamati] and those who have been frequently accused [accusationibus ingravati] shall be placed under surety.' Commoners frequently accused of theft who are at last found guilty by way of the ordeal or who are caught in the act, shall have their hand or foot cut off (Laws of Ine), $\mathrm{p} 49$.
} 
bad repute' who were then required to provide surety. ${ }^{428}$ This is understandable since all other persons would be in frankpledge and, as part of that, they provided surety (by subscribing to a common fund) to cover any BOTP by any person in their group. However, persons of ill fame were, ipso facto, outside frankpledge;

- In the time of king Canute (1016-35), every trustworthy man 'who has never earned a bad reputation and who has never failed either in oath or in ordeal' could clear himself in the hundred court by a simple oath of exculpation. For an untrustworthy man (infamous man) it was much more difficult. ${ }^{429}$

Anglo-Saxon concepts of persons of 'good fame' and 'not of good fame' (infamous) continued into medieval law. ${ }^{430}$ Thus, in the time of Edward I (1272-1307) the word of the sovereign alone (or Parliament) was sufficient to condemn a person of ill fame to death for treason. ${ }^{431}$

- As it is, with the decline in outlawry, ill fame tended to merge into the concept of the 'vagabond', the landless man - one who was endlessly punished in statutes including the Vagrancy Act 1824 (still extent in part). ${ }^{432}$ References to reputation are also encountered as late as Victorian legislation; ${ }^{433}$

- In the context of the 1361 Act it is likely reference was to those "not of good fame' 434 since this reflected the position under Anglo-Saxon - and early medieval - law. That is, infamous persons (those not in frankpledge) were required to provide surety against their (anticipated) future criminality. Confusion in the Act is caused by reference to the 'others [les autres] duly to punish'. However, in the original Law French (Anglo-Norman) the meaning is clearer. Infamous persons were to provide surety but the 'others' (i.e. those who had committed crimes ('offenders, rioters, and all other barrators...') as previously referred to in the Act), the JP's were 'duly to punish'. Thus, the Act is intelligible - and in accordance with the law then prevailing - if the word ' $n o t$ ' is included; ${ }^{435}$

- As it is, the reference to 'fame' in the Act today is wholly superfluous since the English common law no longer categorises persons into those of good fame (reputation) or not;

- Further, this categorisation is illogical anyway since there is no proof that just because a man has committed, for example, theft or murder once, it should be assumed he will do so again. And, the fact that a person has not committed a crime does not mean he will not do (or threaten to do) so. ${ }^{436}$

In short, reference to 'fame' (or not) in the 1361 Act is obsolete and no longer required.

\section{(d) 1361 Act - BOTP \& Good Behaviour}

If the 1361 Act is repealed, the 1968 Act, s 1(7) still makes reference to:

\footnotetext{
${ }^{428}$ Ibid, p 67. Also 'and every man of bad repute [tithbynsigman] shall go to the triple ordeal or pay fourfold [the value of the goods involved].' Also 'if anyone is accused of furnishing with food a man who has broken our lord's peace, he shall clear himself with three times twelve compurgators who shall be nominated by the reeve.'

${ }^{429}$ Ibid, p 185 'for an untrustworthy man compurgators for the simple oath shall be selected within three hundreds, and for the for the triple oath throughout the district under the jurisdiction of the borough court; otherwise he shall go to the ordeal.' See also p 189 (thoroughly untrustworthy men), p 193 (concerning untrustworthy men).

${ }^{430}$ See Laws of Henry I (c.1113), n 42, pp 213-4 (concerning men of ill repute because of frequent accusations (de homine infamato). Also, persons of suspicious character (suspectam personam), Ibid, p 233

${ }^{431}$ Thus, Mortimer (in 1330) was condemned by Parliament on the basis of his notorious crimes (ce qe notoire chose est et conue a touz). In the reign of Edward I (1272-1307) various people were executed on the basis of the notoriety of their crimes. See GS McBain, Abolishing 'High Crimes and Misdemeanours' and the Criminal Processes of Impeachment and Attainder (2011) 85 ALJ, pp 815, n 36 \& 818, n 66.

432 This Act categorised vagrants as; (a) idle and disorderly persons; (b) rogues and vagabonds; and (c) incorrigible rogues.

${ }^{433}$ See e.g. Metropolitan Police Act 1839 (s 35, 'common prostitutes' and 'persons of notoriously bad character'). Also, equivalent sections in the Town Police Clauses Act 1847 (it extended the 1839 Act to towns outside the metropolitan police district).

${ }^{434}$ This was what Blackstone thought, n 151, vol 4, p 253. Cf. Williams, n 253, p 716, n 1 (he thought the word 'not' was originally there, but had a different explanation as to why it was there. However, he did not discuss the early law, including Anglo-Saxon law). Many earlier texts also read the 1361 Act as including the word 'not'. e.g. R Kilburn, Office and Duty of a Justice of Peace ( $8^{\text {th }}$ ed, 1715)(good behaviour) 'Those who are of ill fame... may be required...to be of good behaviour; and upon refusal, may be committed.'

${ }^{435}$ If ' $n o t$ ' was included in the original wording of the Act, does this mean that JP's have consistently erred in binding over persons of good fame? The answer is 'yes'. However, one would also argue that JP's were (and are) simply exercising common sense in that, the fact a person had an unblemished reputation (i.e. had committed no crime previously) did not mean, in the instant case, he had not - or threatened to do so (see e.g. Lansbury, n 256). In other words, the law must reflect prevailing customs and concepts and not those of some 650 or more years ago. See also $R$ (Rusbridger) v $A G$ [2003] UKHL 38, [2004] 1 AC 337, per Lord Walker, pp 377-8 'it is most undesirable that obsolete statutes should remain unrepealed. Quaint language and interesting historical associations are no justification for preserving obsolete statutes in a mummified state.'

${ }^{436}$ It also militates against the purpose of the Rehabilitation of Offenders Act 1974.
} 
the power to bind over to keep the peace and power to bind over to be of good behaviour, a person who or whose case is before the court, by requiring him to enter into his own recognizances or to find sureties or both, and committing him to prison if he does not apply. (italics supplied)

It is asserted that the bifurcation of the power to bind over into: (a) BOTP; and (b) good behaviour, is both confusing - since good behaviour (good abearing) was also linked to frankpledge - and no longer required since the cumulative effect of the two, is to enable JP's to bind over for any criminal (or threatened criminal) offence. In respect of this, the analysis of Williams is instructive:

\section{(i) BOTP}

Williams thought that BOTP, for the purpose of the 1361 Act, 'involves some danger to the person' or 'danger of personal violence'. Thus:

the power to bind over to keep the peace depends upon evidence that the complainant was in danger of personal violence from another by reason of threats (express or implied from conduct), or of an actual assault, is shown by $R v$ Dunn (1840). It was there held that continual pestering of a woman by a man was not enough. ${ }^{437}$

\section{(ii) Good Behaviour}

However, Williams also noted that:

$R v$ Dunn was concerned with binding over to keep the peace, and decided nothing with regard to the power to bind over to be of good behaviour. There is no doubt that this power is wider than and inclusive of the former, so that this power is wider than and inclusive of the former, so that the restrictions on the former power are apt to be illusory; they can so easily be circumvented by relying on the latter. Anyone can lay an information to have the offender bound over to be of good behaviour.

It is clear that a person may be bound over to be of good behaviour if he has committed or threatened any criminal offence, whether or not it involves any blemishing of the peace on his part, and whether or not the offence is otherwise within the jurisdiction of magistrates...Lansbury $v$ Riley decided that a person who incited militant suffragettes to commit crimes (e.g. of malicious damage) could be bound over to be of good behaviour, although no one has been put in bodily fear. The case is well in line with others and contributed nothing new. ${ }^{438}$ (italics supplied and wording divided for ease of reference)

Williams hit the nub of the issue. Binding over for good behaviour can cover any criminal offence, whether committed or threatened. And it may be sought by any citizen. It would also seem wholly appropriate. After all, it is the primary job of all judges (including JP's) and the police to ensure that the criminal law is upheld and that all crimes are punished - whether serious or not - since the very fact that they are crimes is indicative that the acts leading to them detrimentally affect the public interest.

In conclusion, the JPA 1968 should be amended to provide that JP's have the power to bind over a person for committing - or threatening to commit - a crime. This would also clarify that JP's have no such power when no crime is committed, threatened or incited. ${ }^{439}$ The latter assists human rights.

\section{Consolidating Legislation on Magistrates' Courts}

In order to help JP's it would be very useful to consolidate present legislation on magistrates' courts. Indeed, on all other courts. This could be achieved relatively simply if the following were done:

- Obsolete Courts. There are a number of obsolete courts which are no longer required. Their jurisdiction should be transferred to the magistrates' courts, county courts, or the High Court (see Appendix B);

\footnotetext{
${ }^{437}$ Williams, n 253, p 715. Today, 'continual pestering' would likely comprise harassment.

${ }^{438}$ Ibid, pp 715-6. For Lansbury, see n 256..

${ }^{439}$ See 15 (a). As noted, one is dubious whether JP's have often bound over persons who have not committed or threatened to commit a crime, or incited others to do so (and all the examples Williams provides would now be covered by harassment). See also the apt words of Dicey (cited by Williams, n 253, p 717) 'no man is punishable or can be lawfully made to suffer in body or goods except for a distinct breach of law established in the ordinary legal manner before the ordinary courts of the land.' The citation is from AV Dicey, Introduction to the Study of the Law of the Constitution ( $8^{\text {th }}$ ed, 1885, re Liberty Fund Pub., 2010), p 110.
} 
- Judicial Committee of the Privy Council ('JC'). The JC hears few cases from British Overseas Territories (BOT) ${ }^{440}$ now. This will further decline - not least, since a separate Caribbean court has been established. If provision is made for: (a) the Supreme Court to sit as the JC, as and when required; (b) the statutory jurisdiction of the JC to pass to the High Court and Court of Appeal; ${ }^{441}$ and (c) its rules to the dovetailed with those of the Supreme Court, then the antiquated legislation governing the JC can be repealed (see Appendix D) and legislation on all the courts can be consolidated into one Act, see Appendix E);

- Court Martial Court of Appeal. This handles few cases. It could usefully be merged with the Court of Appeal. $^{442}$

If the above were undertaken, legislation on the magistrates' courts (and, indeed, all other courts) could then be placed into one Act (see Appendix E). This would be not only helpful to JP's, but to all lawyers, judges and interested parties.

In conclusion, obsolete courts should be abolished and legislation on courts consolidated into one Act.

\section{Professionalisation of JP's}

The Report of the Royal Commission on Justices of the Peace 1946-48 ${ }^{443}$ made various recommendations on the appointment and qualifications of JP's. However, it was a smaller report of Lord Merthyr which is of note, because (although dissentient), it proved to be correct on various matters. ${ }^{44}$ Two matters he referred to are of worth today.

\section{(a) Lord Mayor of the City of London}

Lord Merthyr (in 1948) asserted that there should be no JP's ex officio. He stated, inter alia:

I agree that the chairman of the councils of counties and of urban and rural districts should cease to be justices ex officio. I however emphatically disagree that mayors of boroughs should be excepted from this recommendation... The case for retaining the mayor as a justice is based very largely on tradition. Tradition commands due respect; but it should never be allowed to retard progress. I think that local government and the administration of justice should be separated as far as possible, since a man may be excellently qualified for the former but have no aptitude for the latter. ${ }^{445}$

Today, mayors are not, ex officio, JP's. However, an anomaly still remains.

- The Lord Mayor of the City is still declared to be the chief magistrate of the City - although this title never seems to have derived from any charter and he no longer sits as a JP; ${ }^{446}$

- The Lord Mayor is also entitled (as are the aldermen and sheriffs) to sit as a judge of the Central Criminal Court.

However, the Lord Mayor does not presently sit qua judge. Further, it would not seem appropriate for him to so sit - not least since he does not have the relevant legal qualifications and his post as mayor, being of a 'political' or 'quasi-political' nature, could give rise to suggestions of bias.

In conclusion, the title of 'chief magistrate' of the Lord Mayor of the City of London should be abolished. So too, any entitlement to sit as a judge (as well as that of any sheriff or alderman of the City).

\section{(b) Stipendiary Magistrates}

Lord Merthyr (in 1948) asserted that professional JP's (stipendiary magistrates) should gradually replace their colleagues. Noting that Ireland (north and south) had only stipendiary magistrates and that the bulk of magisterial work in Scotland was performed by sheriffs (and their substitutes) ${ }^{447}$ he asserted that:

\footnotetext{
${ }^{440}$ See British Overseas Territories Act 2002 (British Virgin Islands, Cayman Islands, Falkland Islands, Gibraltar, Monserrat, Pitcairn Islands, South Georgia and Sandwich Islands, Base areas of Akrotiri and Dheklia in Cyprus, Turks and Caicos Islands, Anguilla, Bermuda, British Antarctic Territory, British Indian Ocean Territory).

${ }^{441}$ See GS McBain, Modernising the English Court System - Time for a Gastric Band. Journal of Politics and Law (2013), vol 6, no 3, pp 18-28.

${ }^{442}$ Ibid, pp 30-2.

${ }^{443}$ Cmnd 7463 (July 1948).

${ }^{444}$ He disapproved of JP's in Lancashire not being appointed by the Lord Chancellor.

${ }^{445}$ See n 4436, p 98.

446 See GS McBain, Liberties and Customs of the City of London - Are there any Left? (2013) Int. Law Research, vol 2, no 1, p 21.

${ }^{447}$ See n 446, p 100 'Under the Summary Jurisdiction and Criminal Justice Act of the Northern Ireland Parliament passed in 1935, that country is, like Eire, covered entirely by stipendiary magistrates. I have no reason to think that administration of justice there is less efficient than in
} 
I think it is merely a question of time before lay justices disappear. It is a question not of whether but of when they should be replaced by professionals...I do not think that the present system ought wholly or indefinitely to be continued. On the contrary I think that there should be a gradual transition from lay to professional magistrates, at least to the extent of a professional presiding over every court. ${ }^{448}$

In conclusion, more stipendiary magistrates should be created and this should be an on-going process.

\section{Conclusion}

The law on 'peace' and BOTP is antiquated and confused. It is ripe for modernisation. Thus, it is asserted that 'Peace' is the same as 'the peace', the 'Queen's peace' and the 'public peace' and - by 1977 at the latest - all criminal courts were upholding that peace, which reference was the same as one to the criminal law. Further, BOTP means the same, generally, as a breach of the criminal law Given this, it is asserted that the law should be modernised as follows:

- $\quad$ Frankpledge \& Hue \& Cry. These common law obligations - long obsolete - should be abolished;

- Justices of the Peace Act 1361. This Act is spent - including the right of JP's to bind over for good behaviour. It should be repealed since the Magistrates' Courts Act 1980 now covers all (non-obsolete) matters referred in the former;

- Justice of the Peace Act 1968, s 1(7). This section should be amended to exclude reference to binding over for 'BOTP' and for 'good behaviour'. Instead, to make it more intelligible in modern times, it should refer to a power to bind where a person: (a) has committed a crime; or (b) threatened to commit a crime; or (c) incited another to commit a crime; ${ }^{449}$

- BOTP- Duty of Constable. The common law duty of a constable to prevent 'breaches of the peace' should be replaced by a statutory duty, requiring a constable to 'do his best to prevent the commission of crime' (following Watkins LJ in Howell);

- Citizen - Arrest without Warrant. This common law power should be abolished since the PACE 1984, s 24A now adequately covers matters;

- Constable - Arrest without Warrant. This common law power should be abolished since the PACE 1984, s 24 now adequately covers matters (or should be slightly amended to do so). Further, this section should be amended to also cover where a constable does not arrest as such but 'restrains', 'detains' or 'removes' a person, since these acts are often part of arrest or closely connected to it;

- Constable - Entering Private Premises. This common law power should be abolished since the PACE 1984, s 17 adequately covers matters (or should be slightly amended to do so).

Also, the following should be undertaken (which can be separate to the above):

- Criminal Legislation. All criminal legislation should be consolidated into 4-5 Acts - in order to help JP's with their work and to make the law more accessible and efficient;

- Courts Legislation. Legislation relating to magistrates' courts should be consolidated - along with that relating to the other courts - into one Act (with obsolete courts being abolished and others merged). This, in order to make the court system more efficient and intelligible;

- More Stipendiaries. JP's should now be professional lawyers - given the increasing complexity of criminal law and the need to ensure the greatest prospect of justice being secured;

- Local Legislation. Given that the Public Order Act 1936, s 5 (which referred to BOTP) has been repealed (in 1986) any local Acts which make reference to BOTP should also be repealed. They are unnecessary; the general law should govern.

England, and I have not heard of any difficulty in recruiting sufficient magistrates. It is true that in Scotland a small proportion of the work remains in the hands of lay justices. The bulk of it however is done by the sheriffs and substitute sheriffs, who are professionals comparable to metropolitan or stipendiary magistrates in England. I think that the Irish system could profitably be extended to England.' On Scotland see also pp 102-3.

448 Ibid, pp 99-100.

449 eg, something to the effect that the Justice of the Peace Act 1968, s 1 (7) is amended as follows: Any court of record having a criminal jurisdiction (including a magistrates' court): (a) has, ancillary to that jurisdiction, a power; (b) to require a person who (or whose case) is before the court ; (c) to provide a recognizance or one (or more) sureties or both; (d) and to commit him to prison, if he fails to comply. which power may only be exercised where that person has: (e) committed a crime; or (f) threatened to commit a crime; or (g) incited one (or more) persons to commit a crime; or (h) if the court reasonably believes there is a risk he will commit a crime in the immediate future. 


\section{$\underline{\text { Appendix A }}$}

CK Allen
Anon
Anon
JF Archbold
JF Archbold
CA Beard
S Blackerby
E Bohun
J Bond
R Boyd
R Burn
R Chamberlayne
M Dalton
W Dickinson
W Eagle
A Fitzherbert
W Fleetwood
JH Gleason
J Keble
R Kilburn
J Kitchin
G Jacob
W Lambard(e)
H L'Estrange
T Marow
W Nelson
GC Oke
B Osborne
BH Putnam
Royal Commission
W Sheppard
T Skyrme
J Stone
S Stone

The Queen's Peace (Hamlyn Lectures, 1953).

The Boke of Justices of the Peace (1506) ${ }^{450}$

The Practick Part of the Office of a Justice of the Peace (1682)

The Justice of the Peace and Parish Officer ( $1^{\text {st }}$ ed 1840, last 1855)

Jervis's Acts relating to the Duties of Justices of the Peace (1849)

The Office of Justice of the Peace in England in its Origin and Development (1967)

The Justice of the Peace his Companion $\left(1^{\text {st }}\right.$ ed 1711 , last ed 1749)

The Justice of the Peace (1693)

A Complete Guide for Justices of the Peace (1692)

Powers and Jurisdiction of HM's Justices of the Peace and Commissioners of Supply (1787)

The Justice of the Peace and Parish Officer ( $1^{\text {st }}$ ed 1755 , last ed 1869)

The Complete Justice (1681)

The Country Justice ( $1^{\text {st }}$ ed 1618 , last ed 1747)

The Office and Duties of a Justice of Peace (1813)

Magistrates' Pocket Companion (1839)

L'Office et Auctoryte des Justyces de Peas ( $1^{\text {st }}$ ed 1538 , rev and enlarged R

Compton, 1584) ${ }^{451}$

Office of a Justice of Peace (1658)

Justices of the Peace in England 1558-1640 ( $\left(1^{\text {st }}\right.$ ed, 1969)

An Assistance to Justices (1683)

Choice Presidents upon all Acts of Parliament relating to the Office and Duty of a Justice of the Peace ( $1^{\text {st }}$ ed, 1680 , last ed $\left(8^{\text {th }}\right.$ ed $\left.), 1715\right)$

The Authority of all Justices of Peace (1580)

The Modern Justice $\left(1^{\text {st }}\right.$ ed, 1716 , last ed 1729)

Eirenarcha $\left(1^{\text {st }} \text { ed } 1581 \text {, last ed } 1619\right)^{452}$

Justices' Law (1770)

Lectures $(1503)^{453}$

The Office and Authority of a Justice of the Peace ( $1^{\text {st }}$ ed, 1745)

The Magisterial Synopsis $\left(1^{\text {st }}\right.$ ed, 1848 , last ed $\left.\left(14^{\text {th }}\right) 1893\right)$

Justices of the Peace 1361-1848 $\left(1^{\text {st }}\right.$ ed, 1960)

Proceedings before the Justices of the Peace in the Fourteenth and Fifteenth Centuries (Ames Foundation, 1938). ${ }^{454}$

Justices of the Peace 1946-8 (Cmnd, July 1948).

Sure Guide for his Majesties Justices of the Peace ( $1^{\text {st }}$ ed, 1649 , last ed 1669)

Whole Office of the Country Justice of Peace $\left(1^{\text {st }}\right.$ ed, 1650 , last ed $\left.\left(3^{\text {rd }}\right) 1655-6\right)$

History of the Justices of the Peace (3 vols, 1991)

The Practice of Petty Sesssions ( $1^{\text {st }}$ ed 1836, last ed, 1882)

The Justices' Pocket Manual ( $1^{\text {st }}$ ed 1842, latest ed - current)

\footnotetext{
${ }^{450}$ Reprinted by Professional Books (1972). For a list of treatises of the $15^{\text {th }}$ and $16^{\text {th }}$ century on JP's, see BH Putnam, Oxford Studies in Social and Legal History (1924), vol 7.

${ }^{451}$ Both Fitzherbert and Crompton (ed) were reprinted by Professional Books (1972).

${ }^{452}$ Eirenarcha (1581) reprinted by Law Book Exchange.

${ }^{453}$ Contained in Putnam.

${ }^{454}$ Putnam estimated there were printed between 1506-99 at least 57 editions or issues of treatises for JP's.
} 


\section{Appendix B: Obsolete Courts}

\section{(a) Courts referred to in Administration of Justice Act 1977, s 23}

This Act, s 23 specifies a number of courts which - from 1977 - ceased to have any jurisdiction to hear, and determine, legal proceedings but which might continue to 'sit and transact such other business, if any, as was customary for it' prior to the coming into force of the Act. The courts referred to comprise:

- $\quad$ courts baron (ie. manorial courts exercising civil jurisdiction);

- $\quad$ courts leet (ie. manorial courts exercising criminal jurisdiction);

- $\quad$ customary courts of the manor (ie. manorial courts exercising civil jurisdiction re copyholders); ${ }^{455}$

- $\quad$ courts of pie poudre (piepowder)(ie. temporary courts at fairs and markets administering the law merchant); ${ }^{456}$

- $\quad$ courts of the staple (courts in designated towns which dealt with claims of merchants, especially foreign ones); ${ }^{457}$

- courts of clerks of the market (courts in fairs and markets which punished for false weights and measures);

- $\quad$ hundred courts (courts of hundreds, when shires were divided into the same, dealing with civil and criminal matters);

- $\quad$ law days (it signified a court leet or sheriff's tourn);

- $\quad$ views of frankpledge (where subjects, in groups of 10 households, agreed to be mutually responsible for each other);

- $\quad$ common law (or sheriffs') county courts as known before the passing of the County Courts Act 1846.

Section 23 also referred to various specific courts (sch 4, pts $2 \& 3$ ), all of which fell within the above categories. It is asserted that all such courts should now be abolished (with any criminal jurisdiction they possess being transferred to the relevant magistrates' court and any civil jurisdiction to the county court) since, in practice, since 1977 they have not sat for any legal purposes and such 'customary purposes' they now perform are simply ceremonial (including the estray court of Denbigh and court leet of the manor of Laxton). Further, such courts do not meet the requirements of the European Human Rights Convention, art 6 (see HRA 1998) which requires an 'independent and impartial tribunal' established by law.

\section{(b) Court of the Chamberlain of the City of London (City of London apprentices' court)}

This court determined disputes between masters and apprentices in the City of London (now, the Square Mile), with the chamberlain sitting as a judge and the comptroller (controller) as his deputy. It administered criminal punishment of apprentices and masters, concurrent with that of a magistrates' court. This court does not appear to have sat for, at least, 100 years and in 1894, a Royal Commission recommended its abolition. Further, this court would not meet the requirements of the European Human Rights Convention, art 6 (see above, the chamberlain of the City of London is not necessarily a lawyer).This court should be abolished (it would seem unnecessary for any jurisdiction to be transferred to the magistrates' court since it had concurrent jurisdiction with it anyway).

\section{(c) Court of the Duchy Chamber of Lancaster (Duchy of Lancaster chancery court)}

This was held before the Chancellor of the duchy (or his deputy) and had jurisdiction concerning equities relating to land held of the Queen in the duchy. ${ }^{458}$ Its jurisdiction was concurrent with that of the courts of Exchequer and Chancery (now part of the High Court). This court has not sat since 1835. Further, this court would not meet the requirements of the European Human Rights Convention, art 6 (see above). This court should be abolished. It would seem unnecessary for any jurisdiction to be transferred to the High Court since it had concurrent jurisdiction with it anyway.

\section{(d) High Court of Chivalry (Armorial court)}

This court last sat in 1954 (in the Royal Courts of Justice, with the LCJ acting as surrogate for the earl marshall (the Duke of Norfolk)) and, prior to that, in 1737. It seems now only to have jurisdiction re armorial matters. This court would not meet the requirements of the European Human Rights Convention, art 6 (see above) if the earl marshall were to sit as a judge. This court should be abolished (including any criminal jurisdiction), any civil jurisdiction being transferred to the High Court (Admiralty).

\section{(e) Cinque Ports Court of Admiralty (Cinque Ports admiralty court)}

This court last sat in 1914 (with the Cinque Ports Act 1821 providing for its jurisdiction to extend from Shore Beacon in Essex to Redcliffe in Sussex). Its marshall had his office merged with that of the admiralty judge of the Cinque Ports, an office usually held by a High Court admiralty judge (his full title is 'Judge Official and Commissary of the Court of

\footnotetext{
${ }^{455}$ Copyhold was abolished in 1925.

456 The last piepowder court sat in 1898

${ }^{457}$ The towns where 'staple courts' were to be held were laid down in legislation, all of which has now been repealed.

${ }^{458}$ For the historical position see Crabb, n 59, p 508. See also Holdsworth, n 35, vol 1, pp 21-2.
} 
Admiralty of the Cinque Ports'). This court should be abolished and the Cinque Ports Acts $1821^{459}$ and $1855^{460}$ repealed, with any salvage jurisdiction transferred to the High Court.

\section{(f) Courts of the Vice-Admirals of the Coast (Local admiralty court)}

The sea coast of England and Wales was divided into 19 districts - for each of which a Vice-Admiral of the coast could be appointed by letters patent, representing the Lord High Admiral. These courts had jurisdiction over all causes of merchants and mariners, happening on the sea or in foreign parts within the king's dominions. Also, of crimes within the above limits, and of all maritime causes where the common law could give no remedy. These courts were said, in 1884, to have fallen into desuetude within the last 100 years. ${ }^{461}$ These courts should be abolished, any jurisdiction being transferred to the High Court.

\section{(g) Colonial Courts of Admiralty and Vice Admiralty (Colonial admiralty courts)}

The Colonial Courts of Admiralty Act 1890 provided for the establishment of the above in colonies - now the 14 British overseas territories. ${ }^{462}$ It is unclear whether any such exist. These courts should be abolished, with any jurisdiction (including prize jurisdiction) passing to the High Court in the case where any BOT does not otherwise have jurisdiction pursuant to an SI under the 1890 Act (there appear to be no SI's). Consideration should also be given to repealing the 1890 Act and simply providing that any civil court in a BOT shall have admiralty jurisdiction and, failing the presence of the latter, the High Court.

\section{(h) Court of the Lord High Steward (House of Lords, Impeachment court)}

This court (instituted in the reign of Henry IV (1399-1413)) handled impeachments when Parliament was not sitting (otherwise the Lord Chancellor sits). The last impeachment was in 1806, the last successful one was in 1746. This court is defunct, since it cannot now sit: the judges who sat in the House of Lords being its judges when Parliament was not otherwise sitting. ${ }^{463}$ Even if abolished, impeachments could still be heard with Lord Chancellor sitting. ${ }^{464}$ This court does not appear to have sat after the Glorious Revolution in 1688 (the few later being conducted when Parliament was sitting).

\section{(i) Court of Claims (Coronation claims court)}

This court handles claims to attend the coronation of a monarch. The nature, and proceedings, of this court has always been very uncertain (e.g.whether there is a right to appeal). The court that sat for Elizabeth II in 1952 comprised the Lord Chancellor, Earl Marshall (Duke of Norfolk, not a judge), Lord Clarendon (not a judge), Lord Jowitt, Lord Porter, Lord Goddard LCJ, Lord MacDermott (LCJ, Northern Ireland), Lord Cooper (Lord President, Court of Session) and Sir Francis Evershed (Master of the Rolls). Thus, this court may not satisfy the ECHR, art 6 (see above) in that it is purporting to determine an issue legally. It would seem appropriate (not least, to permit an appeal) for the jurisdiction of this court to pass to the High Court.

\section{(j) Courts of Attachment of the New Forest and Forest of Dean (Forest courts)}

These courts, also called 40 day courts, inquired into infractions of the forest law in respect of vert and venison in the New Forest and the Forest of Dean, but could not convict. However, forest law was abolished by the Wild Creatures and Forest Laws Act 1971. These courts should be abolished and any jurisdiction transferred to the relevant magistrates' court.

\section{(k) Courts of Verderers of the New Forest and Forest of Dean (Forest courts)}

These courts (also called courts of Swainmote or Swanimote) dealt with infractions of forest law. They are treated as a magistrates' court (New Forest Act 1877, s 33 and Forestry Act 1967, s 47). However, that of the Forest of Dean has not sat since 1902 and, given that the New Forest court also passes New Forest byelaws, it would seem to conflict with the ECHR, art 6. Jurisdiction of these courts should now pass to the relevant magistrates' court.

\section{(l) Barmote Courts of the High Peak \& Wirksworth (Lead mining courts in Derbyshire)}

The Barmote Courts of the High Peak at Monyash (it covers the high peak) and of Wirksworth (it covers the low peak) exercise civil jurisdiction relating to lead mining rights pursuant to the High Peak Mining Customs and Mineral Courts Act

\footnotetext{
${ }^{459}$ The Act provides for the Warden to appoint commissioners for salvage, who have power to determine salvage matters within the jurisdiction of the Cinque Ports (ss 1-6, 12). Since the Warden is now only a ceremonial post and would not so appoint (in the past the Warden was treated as a magistrate) these sections are no longer necessary. It is unclear whether they have ever been availed of.

${ }^{460}$ The 1855 Act removed the privileged jurisdiction of the Cinque Ports re writs and judgments (s 2, now spent), saving the Warden's jurisdiction in the 1821 Act (s 10). This Act is also unnecessary

${ }_{461}$ By 4 \& 5 Will IV c 36 (1835-6) \& 7 Vict 2 (1844), all offences on the high seas and other places within the admiralty of England could be tried in the Central Criminal Court or before ordinary judges of the land.

${ }^{462}$ The Act abolished any existing Vice-Admiralty courts (s 17). Also, it provides that, any court of law with civil jurisdiction in a colony, shall include therein an admiralty jurisdiction (s 2(1)).

${ }^{463}$ B O’Donnell, Calvacade of Justice (1951), p 151.

${ }^{464}$ That said, the House of Lords (it is asserted) can no longer hear impeachments because it no longer has judges to advise them (see also EHCR, art 6).
} 
1851 and the Derbyshire Mining Customs and Mineral Courts Act 1852 It is unclear when these courts last sat in other than a ceremonial capacity (the last lead mine in Derbyshire closed in 1939). Today, they meet (annually) in Wirksworth but only in a ceremonial capacity. This does not meet the requirements of the ECHR, art 6 (see above). These courts should be abolished and any jurisdiction transferred to the relevant county court.

\section{(m) Royal Court of Shepway \& Court of Brotherhood and Guestling (Cinque Ports courts)}

The Royal Court of Shepway (presided over by the Warden of the Cinque Ports), existed by 1150. It exercised civil and criminal jurisdiction within the Cinque Ports (Dover, Sandwich, Romney, Hastings, Hythe) and, later, the two Ancient Towns (Winchlesea and Rye), effectively comprising a shire court. However, its work passed to the Lord Warden's court at Dover and the Royal Court of Shepway became defunct from the $16^{\text {th }}$ century onwards, when its only business then was ceremonial - to meet to install a Warden. The Court of Brotherhood and Guestling (by the $17^{\text {th }}$ century the courts of Brudhull and Guestling had combined) is unlikely to have been a legal court as such. ${ }^{465}$ Rather, an assembly to celebrate special events. Any legal jurisdiction of these courts should be abolished, without prejudice to their assembling for ceremonial purposes, viz the election of a Warden.

\section{(n) Vice Warden's Stannary Court (Devon and Cornwall mining courts)}

At least since 1201, steward's courts existed in the 8 mining districts of Devon and Cornwall (each district being known as a stannary). There was also a second stannary institution - the equitable jurisdiction of the Vice-Warden of the Stannaries. The Stannaries Act 1836 amalgamated the stannary courts into the Vice-Warden's court. The latter, becoming defunct by 1870 (it had with no business), the Stannaries Court (Abolition) Act 1896 abolished it - transferring jurisdiction to the county courts of Cornwall (which still hold this jurisdiction). ${ }^{466}$ The 1836 (ss 4, 6-7), 1855 (s 1) and 1896 Acts (ss 1, 3-4) ) being spent, should be repealed.

\section{(o) House of Lords and Commons as Courts}

The House of Commons (HC) and House of Lords (HL) would, manifestly, appear unable to act as courts having regard to the ECHR, art 6 (see above) being comprised of politicians and lacking judges.

- $\quad$ The HC has long surrendered its judicial jurisdiction on petition - whether original or appellate (it seems to have accepted this since 1399 and re-accepted it in 1621);

- The HL no longer exercises appellate jurisdiction (this has passed to the Supreme Court) and, since 1693, it has not heard original civil petitions;

- $\quad$ The HC and HL exercised criminal jurisdiction by way of impeachment (the $\mathrm{HC}$ acting as petitioner, the HL as the court). However, the last impeachment was in 1806 (last successful one was in 1746) and the process of impeachment, as well as being unnecessary, would not appear to satisfy the ECHR, art 6 . Nor would the passing of Acts of Attainder or of Bills of Pains and Penalties, in which Parliament effectively acts in a judicial capacity (albeit without trial); in the first instance imposing the death penalty.

- The HL has jurisdiction in respect of peerage claims. However, the number of hereditary peers is now declining and new ones cannot enter the House.

- Both Houses try members for breach of their privileges, but have not imposed imprisonment or fines for a long time.

Legislation should provide that the $\mathrm{HC}$ and $\mathrm{HL}$ (whether acting singly or jointly) should no longer act as a court of law. ${ }^{467}$

\footnotetext{
${ }^{465}$ See also Holdsworth, n 35, vol 1, p 64.

${ }^{466}$ See also $R v$ East Powder Justices ex p Lampshire [1979] 2 AE 329 (the power contained in the Magistrates Act 1980, s 2 overrides any vestiges of stannary law in relation to matters which survived repeal by the 1896 Act). Also, per Robert Goff at $\mathrm{p} 335$, any criminal jurisdiction of the stannary courts were abolished by the 1896 Act; it only transferred civil jurisdiction to the county court.

${ }^{467}$ See McBain, n 417.
} 


\section{Appendix C: Breach of the Peace - Cases}

$\underline{\text { Case }}$

\author{
Wise v Dunning
}

Thomas v Sawkins

Duncan v Jones

R v County of London Sessions Appeals C-ee ex p Metropolitan Police C-er

Wilson v Skeock

Piddington v Bates

R v Waterfield \& Lynn

Rice v Connolly

Robson v Hallett

McGowan v CC of Kingston-upon-Hull

King v Hodges

Johnson v Phillips

Kay v Hibbert

Albert v Lavin

Howell

Parkin v Norman

R v CC of Devon and Cornwall, ex p Central Electricity Generating Board $\underline{\text { Year }}$

$1902^{468}$

$1935^{469}$

$1936^{470}$

$1948^{471}$

$1949^{472}$

$1961^{473}$

$1964^{474}$

$1966^{475}$

$1967^{476}$

$1968^{477}$

$1974^{478}$

$1975^{479}$

$1977^{480}$

$1982^{481}$

$1981^{482}$

$1982^{483}$

$1982^{484}$

\section{$\underline{\text { Issue }}$}

Binding over for good behaviour (public meeting).

Right of constable to enter private premises (meeting open to the public).

Obstructiing police officer in execution of his duty (public meeting in street).

Binding over for good behaviour.

Public Order Act 1936, s 5 (now repealed). Also, binding over.

Obstructing a constable in the execution of his duty (Prevention of Crimes Act 1885, s 2). Picketing. Anticipation of BOTP.

Assaulting constable in execution of his duty (OPA 1861, s 38).

Obstructing constable in execution of his duty (Police Act 1964, s 51(3).

Police officers entering private premises. Assaulting constables in the execution of their duty (Police Act 1964, s 51(1).

Wilfuly obstructing constable in execution of his duty (Police Act 1964, s 51(1).

Assaulting constable in execution of his duty (Police Act 1964, s 51(1)). Belief that BOTP about to take place.

Obstructing a constable in the execution of his duty (Police Act 1964, s 51(3)). Refused traffic direction.

Assaulting constable in execution of his duty (Police Act 1964, s 51(1)).

Assaulting constable in execution of his duty (Police Act 1964, s 51(1))

Power of arrest for BOTP. Definition of BOTP.

Public Order Act 1936, s 5 (repealed).

Town and Country Planning Act 1971, s 281(2). Powers of police $r e$ trespassing protestors.

\footnotetext{
${ }^{468}$ [1902] 1 KB 167.

${ }^{469}$ [1935] 2 KB 249.

${ }^{470}$ [1936] 1 KB 218.

${ }^{471}$ [1948] 1 KB 670.

472113 JP 298.See also p 746.

${ }^{473}$ [1961] 1 WLR 162.

474 [1964] 1 QB 164.

475 [1966] 2 QB 414.

${ }^{476}$ [1967] 2 QB 939.

477 [1968] Crim LR 34

478 [1974] Crim LR 424.

479 [1975] 3 AE 682.

480 [1977] Crim LR 226.

481 [1981] 74 Cr App R 150.

482 (1981) 73 Cr App R 31

483 [1982] 3 WLR 523.

${ }^{484}$ [1982] QB 458.
} 


\begin{tabular}{|c|c|c|}
\hline McBean v Parker & $1983^{485}$ & $\begin{array}{l}\text { Assaulting constable in execution of his duty (Police Act } \\
\text { 1964, s 51(1)). }\end{array}$ \\
\hline Joyce v Hertfordshire Constabulary & $1985^{486}$ & Public Order Act 1936, s 5 (repealed). \\
\hline Moss v McLachlan & $1985^{487}$ & $\begin{array}{l}\text { Striking miners stopped from travelling to confront } \\
\text { working miners at a pit. Whether BOTP committed. }\end{array}$ \\
\hline McConnell v CC of Greater Manchester Police & $1990^{488}$ & BOTP on private premises. \\
\hline R v Lamb & $1990^{489}$ & $\begin{array}{l}\text { Right of constable to enter private premises and remain to } \\
\text { prevent BOTP. }\end{array}$ \\
\hline Kerr v DPP & $1995^{490}$ & $\begin{array}{l}\text { Assaulting constable in execution of his duty (Police Act } \\
\text { 1964, s 51(1)). }\end{array}$ \\
\hline Nicol \& Selvanayagam v DPP & $1996^{491}$ & $\begin{array}{l}\text { Protestors sought to disrupt angling competition by } \\
\text { obstructing lines. Refused to be bound over Committed under } \\
\text { Magistrates' Courts lact 1980, s } 115 \text {. }\end{array}$ \\
\hline Foulkes v CC of the Merseyside Police & $1998^{492}$ & $\begin{array}{l}\text { Arrest without warrant. Damages for false imprisonment and } \\
\text { wrongful arrest. }\end{array}$ \\
\hline Redmond-Bate v DPP & $2000^{493}$ & $\begin{array}{l}\text { Christian fundamentalist preaching on cathedral steps. } \\
\text { Refused to stop when asked by a constable. Whether } \\
\text { reasonable to fear imminent BOTP. }\end{array}$ \\
\hline McQuade v CC of Humberside Police & $2002^{494}$ & $\begin{array}{l}\text { BOTP on private premises does not require disturbance to a } \\
\text { member of the public. McConnell (see above) explained. } \\
\text { Charged with obstructing a constable in the execution } \\
\text { of his duty. }\end{array}$ \\
\hline CC of Cleveland Police v McGrogan & $2002^{495}$ & $\begin{array}{l}\text { Claim for false imprisonment and unlawful arrest for } \\
\text { continued detention in a police station. Considered } \\
\text { power to detain to prevent a further BOTP. }\end{array}$ \\
\hline Jarrett v CC of West Midlands Police & $2003^{496}$ & $\begin{array}{l}\text { Arrest by a constable on the basis of a reasonable } \\
\text { ground for suspecting that a non arrestable offence had } \\
\text { been committed. PACE Act 1984, s } 25 \text {. }\end{array}$ \\
\hline $\begin{array}{l}\mathrm{R} \text { (Laporte) v CC of Gloucestershire } \\
\text { Constabulary }\end{array}$ & $2007^{497}$ & $\begin{array}{l}\text { Coach prevented from reaching an air force base. Whether } \\
\text { police reasonably apprehended an imminent BOTP }\end{array}$ \\
\hline Steel v UK & $1999^{498}$ & $\begin{array}{l}\text { BOTP an offence within meaning of art } 5(1)(c) \text { of } \\
\text { Human Rights Convention. }\end{array}$ \\
\hline Williamson v CC of West Midlands Pollice & $2004^{499}$ & BOTP not an offence for the purposes of the PACE Act 1984. \\
\hline Addison v CC of the West Midlands Police & $2004^{500}$ & Whether BOTP constituted an offence. \\
\hline G v Chief Superintendent of the Police, Stroud & $1986^{501}$ & Police Act 1936, s 5 (repealed) \\
\hline Ali v DPP & $2009^{502}$ & $\begin{array}{l}\text { Assaulting a constable in the execution of his duty } \\
\text { ( Police Act 1996, s 89). }\end{array}$ \\
\hline
\end{tabular}

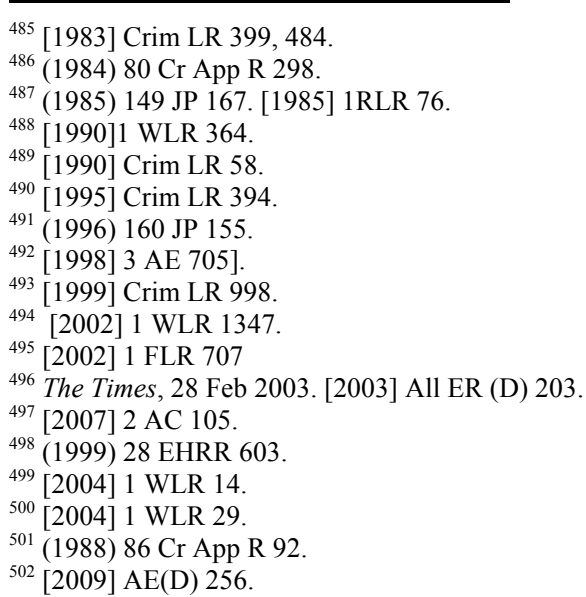




\section{Appendix D: JC}

\section{(a) Judicial Committee Act 1833}

- Judicial Committee of the Privy Council ('JC')(s 1)

- Appeals to the king in Council from sentence of any judge etc shall be referred to the JC to report thereon (s 3)

- His Majesty ('HM') may refer any other matter to the JC (s 4)

- $\quad$ No report to be made unless with the concurrence of the majority of the JC present (s 5)

- $\quad$ Quorum of the JC (s 5A)

- If HM directs the attendance of any JC member (s 6) [obsolete]

- JC make take evidence viva voce or on written dispositions (s 7)

- JC may order witnesses to be examined (s 8)

- Witnesses to be examined on oath (s 9)

- JC may direct new trials of issues (s 13)

- $\quad$ Costs (s 15)

- $\quad$ Decrees of the JC to be enrolled (s 16)

- JC may refer matters to the registrar (s 17)

- Appointment of registrar (s 18)

- $\quad$ Attendance of witnesses etc may be compelled by sub-poena (s 19)

- Time for appeal (s 20)

- Decrees on appeals from abroad to be carried into effect as HM in Council shall direct (s 21)

- HM may make orders for regulating mode etc of appeals (s 24)

- $\quad$ Power of confirming decrees (s 28)

- $\quad$ Saving as to treaties with foreign countries (s 31). [obsolete]

\section{(b) Judicial Committee Act 1843}

- $\quad$ Power of the JC and the surrogates re ecclesiastical and admiralty court appeals (s 2)

- Who are surrogates and examiners of the JC in ecclesiastical and admiralty appeals (s 3)

- Manner of conducting appeals before the JC (s 5)

- $\quad$ Punishing contempts, compelling appearances, enforcing judgments in appeals (s 7)

- Inhibitions etc (s 9) [spent]

- Monitions for transmitting sums into the Admiralty court registry (s 10) [spent]

- Appeals from ecclesiastical courts may be referred to the JC by a general order in council (s 11)

- $\operatorname{Costs}(\mathrm{s} 12)$

- Custody of records (s 14)

- JC empowered to make rules (s 15)

- Definition of terms (s 17)

\section{(c) $\underline{\text { Judicial Committee Act } 1844}$}

- Admission of appeals from a colonial court although not a court of appeal (s 1)

- Appointment of a clerk (s 8)

- Hearing appeals $(s 9)$

- Copies of evidence (s 10)

- $\quad$ Rules (s 11)

- $\quad$ Neglect in compliance (s 12)

\section{(d) Privy Council Registrar Act 1853}

- $\quad$ Registrar may examine witnesses on oath $(s 1)$

- Person to act for registrar (s 2)

- $\quad$ Saving of existing powers (s 3)

(e) Judicial Committee Amendment Act 1895

- $\quad$ Person being a colonial judges (s 1)

\section{(f) Appellate Jurisdiction Act 1908}

- Resignation of JC members (s 4)

- $\quad$ Power to make order (s 5) 


\section{(g) $\underline{\text { Judicial Committee Act } 1915}$}

- $\quad$ Power of JC to sit in more than one division (s 1)

Notes:

1. If new legislation were to provide as described in $\mathbf{2 7}$, the above antiquated provisions could be replaced.

2. Material in italics comprises rules which should be dovetailed with those of the Supreme Court.

3. If the Cinque Ports Court of Admiralty was abolished - and BOT admiralty as well as ecclesiastical appeals directed to the Court of Appeal - reference would no longer need to be made to admiralty and ecclesiastical appeals in any case. 


\section{Appendix E: Courts' Legislation}

If obsolete courts were abolished (see Appendix B) and the legislation on the Judicial Committee of the Privy Council modernised (see Appendix D), all other legislation on courts (see Halsbury, Statutes, vols 11(1) and (2)) could be consolidated into one Act, which would include the following current legislation (17 Acts):

- $\quad$ Magistrates' Courts (Appeals from Binding over Orders) 1956

- $\quad$ City of London Courts Act 1964

- $\quad$ Justice of the Peace Act 1968

- $\quad$ Administration of Justice Act 1969

- $\quad$ Administration of Justice Act 1970

- $\quad$ Courts Act 1971

- $\quad$ Administration of Justice Act 1973

- $\quad$ Administration of Justice Act 1977

- $\quad$ Magistrates Courts Act 1980

- $\quad$ Judicial Pensions Act 1981

- $\quad$ Senior Courts Act 1981

- $\quad$ County Courts Act 1984

- $\quad$ Magistrates Courts (Procedure) Act 1998

- $\quad$ Courts and Legal Services Act 1990

- $\quad$ Courts Act 2003

- $\quad$ Access to Justice Act 1999

- $\quad$ Constitutional Reform Act 2005

\section{Copyrights}

Copyright for this article is retained by the author(s), with first publication rights granted to the journal.

This is an open-access article distributed under the terms and conditions of the Creative Commons Attribution license (http://creativecommons.org/licenses/by/3.0/). 